\title{
Recent Advances in the Oxone-Mediated Synthesis of Heterocyclic Compounds
}

\author{
Helen A. Goulart, Daniela R. Araujo, Filipe Penteado, Raquel G. Jacob, Gelson Perin *(D) and Eder J. Lenardão *(D) \\ Laboratório de Síntese Orgânica Limpa-LASOL-CCQFA, Universidade Federal de Pelotas-UFPel, \\ P.O. Box 354, Pelotas 96010-900, RS, Brazil; helen-goulart@hotmail.com (H.A.G.); \\ daniela.roodriguues@gmail.com (D.R.A.); penteado.filipe@gmail.com (F.P.); raquel.jacob@ufpel.edu.br (R.G.J.) \\ * Correspondence: gelson_perin@ufpel.edu.br (G.P.); lenardao@ufpel.edu.br (E.J.L.); \\ Tel.: +55-53-32757356 (G.P. \& E.J.L.)
}

\begin{abstract}
Oxone is a commercially available oxidant, composed of a mixture of three inorganic species, being the potassium peroxymonosulfate $\left(\mathrm{KHSO}_{5}\right)$ the reactive one. Over the past few decades, this cheap and environmentally friendly oxidant has become a powerful tool in organic synthesis, being extensively employed to mediate the construction of a plethora of important compounds. This review summarizes the recent advances in the Oxone-mediated synthesis of $\mathrm{N}-, \mathrm{O}-$ and chalcogencontaining heterocyclic compounds, through a wide diversity of reactions, starting from several kinds of substrate, highlighting the main synthetic differences, advantages, the scope and limitations.
\end{abstract}

Keywords: Oxone; oxidant; heterocycles; green chemistry

Citation: Goulart, H.A.; Araujo, D.R.; Penteado, F.; Jacob, R.G.; Perin, G.; Lenardão, E.J. Recent Advances in the Oxone-Mediated Synthesis of Heterocyclic Compounds. Molecules 2021, 26, 7523. https://doi.org/ $10.3390 /$ molecules 26247523

Academic Editor: Bartolo Gabriele

Received: 23 November 2021 Accepted: 10 December 2021 Published: 12 December 2021

Publisher's Note: MDPI stays neutral with regard to jurisdictional claims in published maps and institutional affiliations.

Copyright: (c) 2021 by the authors. Licensee MDPI, Basel, Switzerland. This article is an open access article distributed under the terms and conditions of the Creative Commons Attribution (CC BY) license (https:// creativecommons.org/licenses/by/ $4.0 /)$.

\section{Introduction}

The 12 Principles of Green Chemistry, introduced by Anastas and Warner at the end of the 1990s, set guidelines for the development of sustainable and environmentally friendly chemical processes, aiming to reduce and/or eliminate the chemical pollution by improving design, instead of residue treatment. Among them, Principle \#12 (Inherently Safer Chemistry for Accident Prevention) is very important, once it encourages the use of safe substrates and reaction conditions, as well as seeking to eliminate the generation of hazardous substances, reducing the risk of accidents involving explosions, leaks and fires [1-3].

To satisfy this premise, the development of selective protocols, employing green oxidant species and circumventing the use of hazardous oxidants (e.g.,: $\mathrm{KMnO}_{4}, \mathrm{~K}_{2} \mathrm{Cr}_{2} \mathrm{O}_{7}$, $\left.\mathrm{CrO}_{3}, \mathrm{OsO}_{4},{ }^{t} \mathrm{BuOCl}, m-\mathrm{CPBA}, \mathrm{NBS}\right)$, are welcome. Besides being operationally dangerous, some oxidants also produce toxic organic- and heavy metal-based byproducts, enhancing the environmental and health impact [4]. On the other hand, molecular oxygen $\left(\mathrm{O}_{2}\right)$ and hydrogen peroxide $\left(\mathrm{H}_{2} \mathrm{O}_{2}\right)$ are, undoubtedly, important green oxidant reagents, due to the formation of non-toxic and environmentally benign byproducts, besides presenting an excellent atom efficiency. However, transportation and handling of these species are hugely faced problems [5].

In this context, Oxone (a white solid, molar mass $=307 \mathrm{~g} \mathrm{~mol}^{-1}$ ) plays an important role, being a cheap and commercially available compound, composed of three inorganic salts $\left(\mathrm{KHSO}_{5} / 0.5 \mathrm{KHSO}_{4} / 0.5 \mathrm{~K}_{2} \mathrm{SO}_{4}\right)$, among which potassium peroxymonosulfate $\left(\mathrm{KHSO}_{5}\right)$ is the reactive species. Oxone has been widely used as a green oxidant in organic transformations, generating the nontoxic $\mathrm{KHSO}_{4}$ as the oxidant-derived byproduct. Additionally, it is a very safe species, presenting an impressive bench-stability, which makes its transportation and storage not dangerous [6].

Heterocycles are considered one of the most important class of compounds, widely present in nature. They are also valuable in the manufacturing industry (including pharmaceuticals, agrochemicals and materials), in which they play a pivotal role [7,8]. This 
importance is evident regarding that around $60 \%$ of the small-molecule-approved drugs, registered in the U.S. FDA database, are composed of at least one heterocycle unit $[9,10]$. For this reason, the search for simple and efficient methods to access these compounds is constant and intense, with hundreds of new strategies emerging each year.

Regarding the synthetic versatility of Oxone as a green oxidant, and the massive search for the development of innovative and efficient methods to prepare heterocyclic compounds, several studies have been published describing the Oxone-mediated synthesis of heterocycles through a wide diversity of strategies (Scheme 1). Thus, this review aims to emerge a comprehensive discussion about the recent advances in this field, covering the relevant works published between 2013 and 2021. For a better understanding, it is divided in four major sections, which involve the synthesis of nitrogencontaining heterocycles, oxygen-containing heterocycles, chalcogen-containing heterocycles and miscellaneous cyclizations.

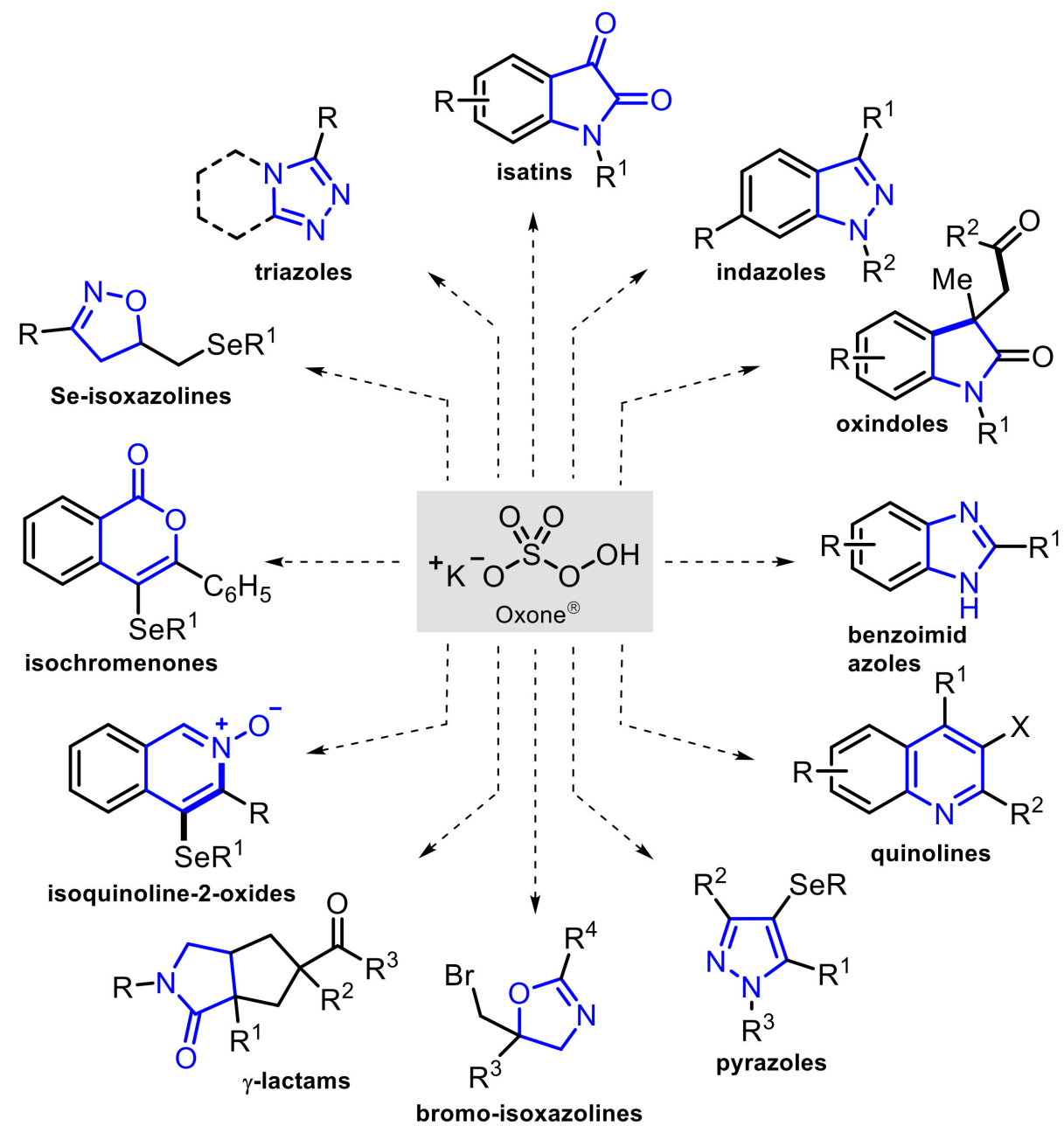

Scheme 1. Oxone-mediated synthesis of heterocyclic compounds.

\section{Nitrogen-Containing Heterocycles}

$\mathrm{N}$-based heterocycles are the most abundant among this important class of compounds [11]. This importance is closely related to some impressive properties, including a wide range of biological activities [12,13], being present in several worldwide marketed drugs [9] and agrochemicals, and are important in the development of functional materials [14]. As a consequence, there is an increasing search, by the scientific community, for the development of efficient methods to access these compounds. Among the recent advances, several Oxone-promoted protocols have emerged as efficient and greener alternatives to prepare $N$-based heterocycles. 
In 2014, Tanimori and co-workers [15] described a transition metal (TM)-free protocol for the synthesis of $N$-arylsubstituted $1 H$-indazole and derivatives 1 (Scheme 2 ). The optimized reaction condition was reached after stirring a mixture of hydrazones 2 , iodobenzene $(10 \mathrm{~mol} \%)$, Oxone (1.5 equiv) and trifluoroacetic acid (TFA), at $-10{ }^{\circ} \mathrm{C}$ for $0.5 \mathrm{~h}$. The cyclization reaction scope was extended to several substituted hydrazones 2 , affording the respective $1 H$-indazoles $\mathbf{1}$ at up to an $84 \%$ yield. Electron-rich disubstituted hydrazones $\mathbf{2 b}$ and $\mathbf{2 c}(\mathrm{R}=\mathrm{Me}$ and $\mathrm{OMe})$, gave the corresponding substituted $1 \mathrm{H}$-indazoles $\mathbf{1 b}$ and $\mathbf{1 c}$ at a $77 \%$ and $71 \%$ yield, respectively. Halogen-substituted hydrazones $\mathbf{2 d}$ and $\mathbf{2 e}(\mathrm{R}=\mathrm{Cl}$ and $\mathrm{F})$ also reacted smoothly to produce the desired products $\mathbf{1 d}$ and $\mathbf{1 e}$ in $73 \%$ and $71 \%$ yield, respectively. It is worth to mention that $p$-methyl monosubstituted hydrazone $2 \mathbf{f}$ provided a 10:1 mixture of the regioisomeric products $\mathbf{1} \mathbf{f}$ and $\mathbf{1 f}^{\prime}$ at a $72 \%$ yield. This problem was not observed when the $p$-methoxy-substituted substrate $2 \mathrm{~g}$ was reacted, yielding the respective product $1 \mathrm{~g}$ (69\% yield) with high regioselectivity, through the annulative process undergoing in the electron-rich ring. Satisfactorily, $p-\mathrm{NO}_{2}$ and pyridinyl hydrazones $\mathbf{2} \mathbf{i}$ and $\mathbf{2} \mathbf{j}$ reacted successfully to afford the products $\mathbf{1 i}$ and $\mathbf{1} \mathbf{j}$ at a $79 \%$ and $77 \%$ yield, respectively. Nevertheless, limitations were also faced when $N$-H, $N$-benzyl and $N$-tosyl hydrazones $2 \mathbf{k}$ m were employed as substrate. In these cases, the desired $1 H$-indazoles $\mathbf{1 k}-\mathbf{m}$ could not be obtained, probably due to the low stability of the nitrenium ion, the key intermediate of the reaction. Hydrazones containing $\mathrm{CO}_{2} \mathrm{Me}$ - and $\mathrm{Me}$ groups $\mathbf{2 n}$ and $\mathbf{2 o}$ were suitable substrates for this reaction; however, the respective indazoles $\mathbf{1 n}$ and $\mathbf{1 0}$ were obtained in poor yields (Scheme 2).<smiles>[R]N/N=[R](/[R])c1ccc([R])cc1</smiles>

2<smiles>[R]c1ccc(-c2nn(C)c3cc([R])ccc23)cc1</smiles>

1a: $\mathrm{R}=\mathrm{H}, 84 \%$

1b: $\mathrm{R}=\mathrm{OMe}, 77 \%$

1c: $R=M e, 71 \%$

1d: $\mathrm{R}=\mathrm{Cl}, 73 \%$

1e: $R=F, 71 \%$<smiles>CCCCCCc1nn(-c2ccccc2)c2cc(OC)ccc12</smiles>
1g: $69 \%$<smiles>[R]n1nc(CCCC)c2ccccc21</smiles>

1k: $\mathrm{R}^{2}=\mathrm{H}, \mathrm{NR}$

1I: $R^{2}=$ benzyl, NR

$1 \mathrm{~m}: \mathrm{R}^{2}=$ tosyl, NR

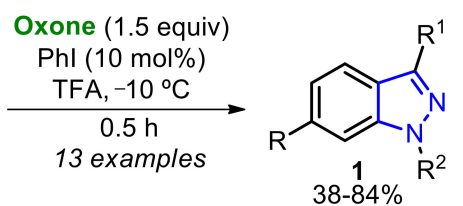

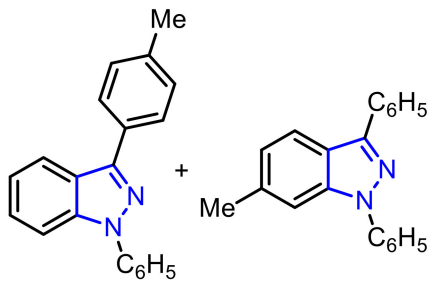

1f/1f' (10:1): $72 \%$<smiles>[R]c1ccc(-c2nn(CCCCC)c3ccccc23)cc1</smiles>

1h: $\mathrm{R}=\mathrm{Br}, 60 \%$ 1i: $\mathrm{R}=\mathrm{NO}_{2}, 79 \%$<smiles>CCCCCn1nc(-c2ccncc2)c2ccccc21</smiles>

1j: $77 \%$<smiles>[R]c1nn(CCCC)c2ccccc12</smiles>

1n: $\mathrm{R}^{1}=\mathrm{CO}_{2} \mathrm{Me}, 39 \%$

10: $R^{1}=\mathrm{Me}, 38 \%$

(performed at $70^{\circ} \mathrm{C}$ )

Scheme 2. Oxone/PhI-promoted annulation of $N$-substituted hydrazones 2.

Based on control experiments, a plausible reaction mechanism was proposed (Scheme 3). Initially, the oxidation of iodobenzene by Oxone affords the hypervalent iodine(III) species 
A, which reacts with 2 to form the nitrenium ion intermediate $\mathbf{B}$. Then, an intramolecular electrophilic substitution provides the carbocation $\mathbf{C}$, which is finally converted to the aromatic product 1.

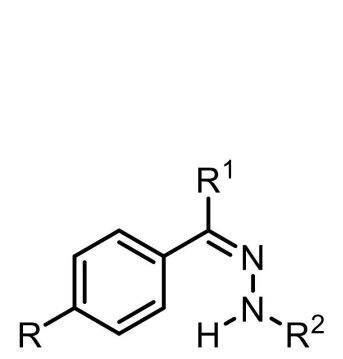

2<smiles>[R]c1ccc2c([R])nn([R2])c2c1</smiles>

1

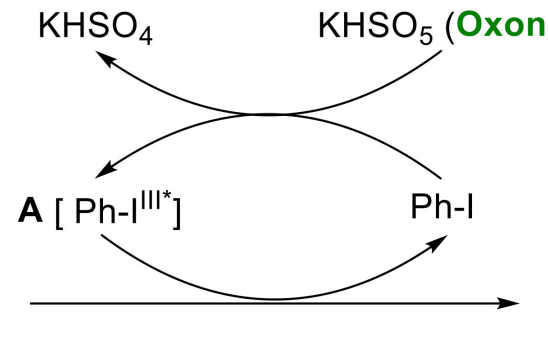

$R^{2}$<smiles>[R]C1=NN([R2])Cc2ccc([R])cc21</smiles>

B

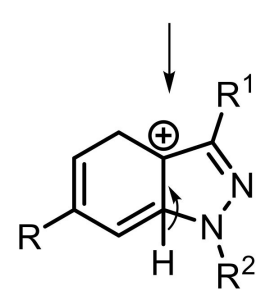

C

Scheme 3. Plausible reaction mechanism for the Oxone/PhI-promoted annulation process.

In 2015, Nagarajan and co-workers reported the synthesis of triazole-fused heterocycles 3 through a one-pot strategy, starting from aldehydes $\mathbf{4}$ and heteroarylhydrazines 5 . The reaction involves the formation in situ of the hydrazone $\mathbf{A}$, which in the sequence is submitted to an Oxone/CuBr-mediated intramolecular oxidative cyclization (Scheme 4) [16]. Through this simple and selective system, several substituted aldehydes bearing a wide range of functional groups were employed as substrate, affording a diversity of triazolefused pyridines, pyridazines, pyrimidine and quinolines 3, in good yields and short reaction times.

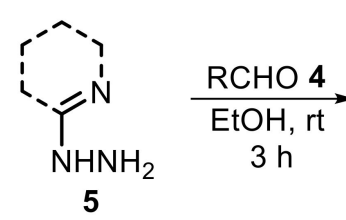

$\mathrm{R}=$ aryl, heteroaryl<smiles>[R]C=NNC1=NCCCC1</smiles>

A

$$
\begin{aligned}
& \mathrm{CuBr}_{2}(10 \mathrm{~mol} \%) \\
& \stackrel{\text { Oxone }(1.0 \text { equiv })}{\underset{\mathrm{H}_{2} \mathrm{O}(2 \mathrm{~mL}), \mathrm{rt}, 3 \mathrm{~h}}{43 \text { examples }}}
\end{aligned}
$$

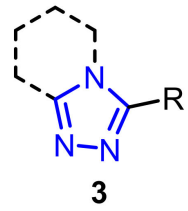

$60-92 \%$

Selected examples<smiles>c1ccc(-c2nnc3ccccn23)cc1</smiles>

3a: $90 \%$<smiles>c1ccc2c(c1)ccc1nnc(-c3ccsc3)n12</smiles>

3e: $70 \%$<smiles>C(=C/c1nnc2ccccn12)\c1ccccc1</smiles>

3b: $80 \%$<smiles>Fc1ccc2cc(-c3nnc4ccc5ccccc5n34)[nH]c2c1</smiles>

3f: $83 \%$<smiles>C=COc1ccc(-c2nnc3ccc(Cl)nn23)cc1</smiles>

3c: $92 \%$<smiles>Brc1ccc(-c2nnc3ncccn23)cc1</smiles>

3g: $75 \%$<smiles>Clc1ccc2nnc(C3CC3)n2n1</smiles>

3d: $75 \%$
Scheme 4. Oxone/CuBr-mediated synthesis of triazole-fused heterocycles 3. 
Additionally, in 2015, Guo and co-workers described the synthesis of oxindoles 6 through an Oxone-mediated reaction between $N$-arylacrylamides 7 and $\alpha$-diketones 8, through a $\mathrm{Csp} p^{2}-\mathrm{Csp} p^{2}$ cleavage and the formation of a new $\mathrm{Csp} p^{2}-\mathrm{Csp} p^{3}$ bond (Scheme 5) [17] The optimized reaction condition was set by using $N$-arylacrylamina $7, \alpha$-diketone 8 , and Oxone ( 2.5 equiv) in THF $(3 \mathrm{~mL})$ as solvent. The resulting mixture was stirred at $100{ }^{\circ} \mathrm{C}$ under $\mathrm{N}_{2}$ atmosphere for $24 \mathrm{~h}$. Under this condition, a total of ten 3-(2-oxoethyl)indolin-2ones 6 was obtained in poor to good yields, employing several electron-rich and electrondeficient substrates $\mathbf{7}$ and $\mathbf{8}$. It is worth to mention that asymmetric $\alpha$-diketones, including 1 phenylpropane-1,2-dione 8a and 1-(4-methoxyphenyl)-2-phenylethane-1,2-dione $8 \mathbf{b}$, were also suitable substrates, resulting a mixture of products $6 \mathbf{a}+\mathbf{6 i}(23 \%$ and $49 \%$ yield) and $\mathbf{6 a}+\mathbf{6 j} \mathbf{j}(43 \%$ and $16 \%$ yield), respectively (Scheme 5).

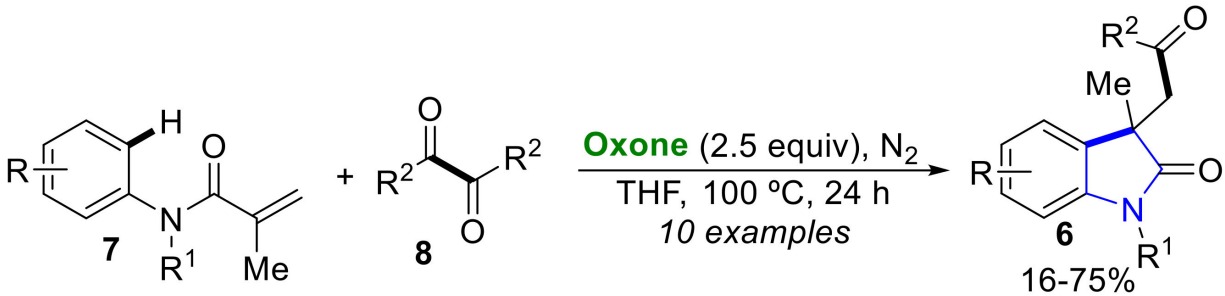<smiles></smiles>

6a: $71 \%$<smiles>CCCCCC1(CC(C)=O)C(=O)N(C)c2ccc(I)cc21</smiles>

6e: $59 \%$<smiles>CCCCCC1(CC(C)=O)C(=O)N(C)c2ccc(F)cc21</smiles>

6b: $68 \%$<smiles>CCCCCCC1(CC(C)=O)C(=O)N(C)c2ccc(Cl)cc21</smiles>

6c: $72 \%$<smiles>CCCCCCC1(CC(C)=O)C(=O)N(C)c2ccc(Br)cc21</smiles>

6d: $64 \%$<smiles>CC(C)=O</smiles>

6h: $70 \%$<smiles>CC(=O)CC1(C)C(=O)N(C)c2ccccc21</smiles>

6i: $49 \%$

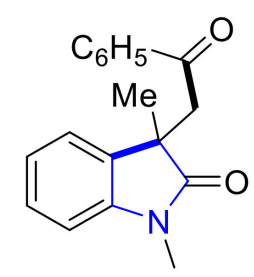

6a: $23 \%$

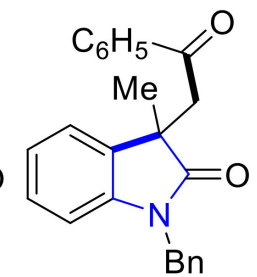

6g: $63 \%$<smiles>COc1ccc(C(=O)CC2(C)C(=[OH+])N(C)c3ccccc32)cc1</smiles>

6j: $16 \%$<smiles>CCCCCCC1(CC(C)=O)C(=O)N(C)c2ccccc21</smiles>

6a: $43 \%$

Scheme 5. Oxone-mediated synthesis of oxindoles 6 .

In 2016, Sen and co-workers employed Oxone as an oxidant in the tandem annulation between 2-aminobenzylamines 9 and aldehydes $\mathbf{4}$, in order to access 2-substituted benzimidazoles 10 (Scheme 6) [18]. The reaction is conducted at room temperature for $8 \mathrm{~h}$, in the presence of Oxone (0.6 equiv), $\mathrm{H}_{2} \mathrm{O}(2 \mathrm{~mL})$ and $\mathrm{DMF}(10 \mathrm{~mL})$, and was suitable to several aliphatic, aromatic and heteroaromatic aldehydes 4 , in the presence of substituted 2-aminobenzylamines $\mathbf{9}$, giving the products $\mathbf{1 0}$ in poor to excellent yields. Limitations were faced when electron-deficient 2-aminobenzylamines $\left(\mathrm{R}=3-\mathrm{NO}_{2}\right)$ were employed as substrate, affording the products $10 \mathrm{c}$ and $10 \mathrm{e}$ in $18 \%$ and $26 \%$, respectively. The process involves the initial condensation between 2-aminobenzylamine 9 and aldehydes 4 , providing 
the tetrahydroquinazoline intermediate $\mathbf{A}$, which undergoes a radical ring distortion to afford the desired products 10, under oxidative conditions (Scheme 6).

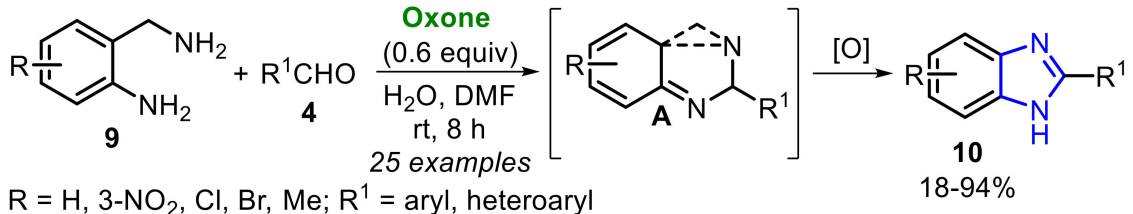

$\mathrm{R}=\mathrm{H}, 3-\mathrm{NO}_{2}, \mathrm{Cl}, \mathrm{Br}, \mathrm{Me} ; \mathrm{R}^{1}=$ aryl, heteroaryl

$18-94 \%$<smiles>O=C(O[Na])OC(=O)O[Na]</smiles>

10a: $45 \%$<smiles>Cc1ccc2nc(-c3ccccc3)[nH]c2c1</smiles>

10b: $67 \%$<smiles>Cc1ccc(-c2nc3ccc([N+](=O)[O-])cc3[nH]2)cc1</smiles>

10c: $18 \%$<smiles>Cc1cc(C)cc(-c2nc3ccccc3[nH]2)c1</smiles>

10d: $94 \%$<smiles>O=[N+]([O-])c1ccc2nc(-c3ccccc3)[nH]c2c1</smiles>

10e: $26 \%$<smiles>Cc1ccc(-c2nc3ccc(Cl)cc3[nH]2)cc1</smiles>

10f: $81 \%$

Scheme 6. Oxone-mediated synthesis of 2-substituted benzimidazoles $\mathbf{1 0}$.

In 2018, Madabhushi and co-workers described an efficient Oxone-mediated protocol for the preparation of 2,3-dihydroquinazolin-4(1H)-ones $\mathbf{1 1}$ and $1 H$-benzimidazoles $\mathbf{1 0}$ (Scheme 7) [19]. The reaction involves stirring a mixture of sec-amines 12, via imine- $N$-oxides, and substituted 2-amino- $\mathrm{N}$-benzamides 13 in the presence of Oxone ( $3.54 \mathrm{mmol})$, in a mixture of THF/water $(2: 1,10 \mathrm{~mL})$ as solvent, affording the respective 2,3-dihydroquinazoline$4(1 H)$-ones 11a $\mathrm{m}$ in moderate to excellent yields. The reaction scope was satisfactorily expanded, and several alkyl and aryl sec-amines 12 were employed, as well as $\mathrm{N}$-substituted benzamides 13, bearing aliphatic, aromatic and heteroaromatic groups.

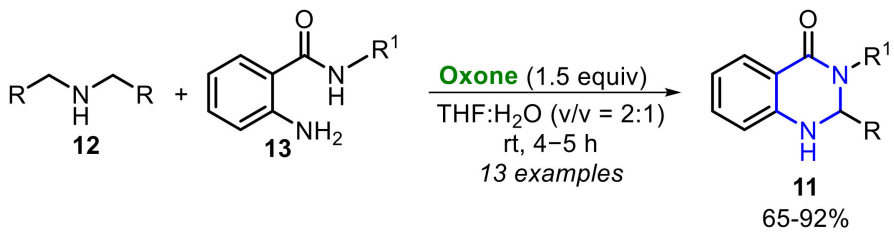<smiles>[R]C1Nc2ccccc2C(=O)N1c1ccccc1</smiles>

11a: $\mathrm{R}=\mathrm{C}_{6} \mathrm{H}_{5}, 89 \%, 5 \mathrm{~h}$ 11b: $R=M e, 92 \%, 4 \mathrm{~h}$

11c: $R=E t, 86 \%, 4 h$

11d: $R=\operatorname{Pr}, 84 \%, 5 \mathrm{~h}$<smiles>[R]N1C(=O)c2ccccc2NC1c1ccccc1</smiles>

11g: $\mathrm{R}^{1}=\mathrm{Bn}, 85 \%, 5 \mathrm{~h}$

11h: $\mathrm{R}^{1}=2-\mathrm{ClC}_{6} \mathrm{H}_{4}, 89 \%, 5 \mathrm{~h}$

11i: $\mathrm{R}^{1}=4-\mathrm{MeC}_{6} \mathrm{H}_{4}, 87 \%, 5 \mathrm{~h}$

$11 \mathrm{j}: \mathrm{R}^{1}=4-\mathrm{MeOC}_{6} \mathrm{H}_{4}, 88 \%, 5 \mathrm{~h}$

$11 \mathrm{k}: \mathrm{R}^{1}=$ cyclopropyl, $81 \%, 5 \mathrm{~h}$<smiles>O=C1c2ccccc2NC([N+](=O)[O-])N1C1CCCCC1</smiles>

11e: $78 \%, 5 \mathrm{~h}$<smiles>O=C1c2ccccc2NC([N+](=O)[O-])N1c1ccc2c(c1)OCO2</smiles>

11I: $81 \%, 6 \mathrm{~h}$<smiles>CC1Nc2ccccc2C(=O)N1Cc1ccco1</smiles>

11f: $84 \%, 5 \mathrm{~h}$<smiles>O=C(O)[C@H]1Nc2ccccc2C(=O)N1c1ccccc1</smiles>

11m: $65 \%, 6 \mathrm{~h}$

Scheme 7. Oxone-promoted synthesis of 2,3-dihydroquinazoline-4(1H)-ones 11a-m. 
Additionally, under the optimized reaction condition, sec-amines 12 reacted with 1,2diaminobenzenes $\mathbf{9}$, affording $1 H$-benzimidazoles 10 in poor to moderate yields (Scheme 8 ). The reaction scope was also investigated, presenting an acceptable substrate tolerance, including the use of substrates bearing the strong electron-withdrawing nitro group $\left(\mathrm{R}^{1}=4-\mathrm{NO}_{2}\right)$.

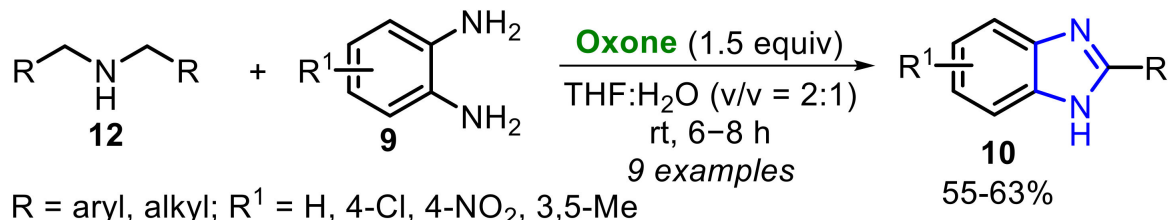<smiles>[R]c1nc2ccccc2[nH]1</smiles>

10g: $\mathrm{R}=\mathrm{Me}, 61 \%, 6 \mathrm{~h}$

10h: $R=E t, 57 \%, 7 \mathrm{~h}$

10i: $\mathrm{R}=\operatorname{Pr}, 60 \%, 8 \mathrm{~h}$<smiles>[R][X]1ccc2nc(-c3ccccc3)[nH]c2c1</smiles>

10j: $R^{1}=H, 62 \%, 6 h$

10k: $\mathrm{R}^{1}=4-\mathrm{Cl}, 65 \%, 6 \mathrm{~h}$

10c: $\mathrm{R}^{1}=4-\mathrm{NO}_{2}, 56 \%, 8 \mathrm{~h}$

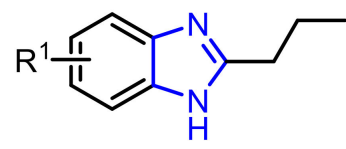

10I: $\mathrm{R}^{1}=4-\mathrm{Cl}, 60 \%, 7 \mathrm{~h}$

$10 \mathrm{~m}: \mathrm{R}^{1}=4-\mathrm{NO}_{2}, 55 \%, 8 \mathrm{~h}$

Scheme 8. Oxone-promoted synthesis of $1 H$-benzimidazoles 10.

In 2018, Tang, Zheng and co-workers [20] described an Oxone/ $\mathrm{NaNO}_{2}$-mediated oxidative radical cyclization of $\mathrm{N}$-methyl- $\mathrm{N}$-arylpropiolamide $\mathbf{1 4}$ to the respective isatins 15 and 16, through the oxidative cleavage of the $\mathrm{C} \equiv \mathrm{C}$ bond, affording the desired products in moderate to good yields (Scheme 9). Despite the low reaction selectivity, the present protocol is important, once $\mathrm{NO}_{2}$-containing isatin derivatives $\mathbf{1 6}$ are satisfactorily afforded, which is not an easy task, from the synthetic point of view.

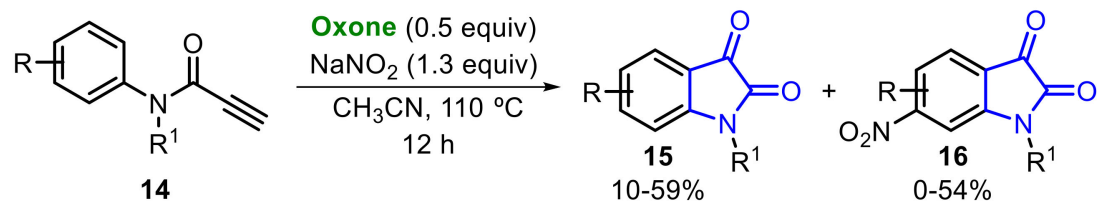

$\mathrm{R}=\mathrm{H}, \mathrm{NO}_{2}, \mathrm{CN}, \mathrm{CF}_{3}, \mathrm{Ac}, \mathrm{CO}_{2} \mathrm{Et}, \mathrm{F}, \mathrm{Cl}, \mathrm{Br}, \mathrm{I}, \mathrm{CH}_{3}, \mathrm{OMe}$

$\mathrm{R}^{1}=\mathrm{Me}, \mathrm{Et},{ }^{i} \mathrm{Pr}, \mathrm{CH}_{2} \mathrm{CCH},\left(\mathrm{CH}_{2}\right)_{2} \mathrm{CN}, \mathrm{C}_{6} \mathrm{H}_{5}$

Selected examples<smiles>CN1C(=O)C(=O)c2ccccc21</smiles>

15a: $32 \%$<smiles>CN1C(=O)C(=O)c2cc(C(F)(F)F)ccc21</smiles>

15c: $59 \%$<smiles>COc1ccc2c(c1)C(=O)C(=O)N2C</smiles>

15e: $24 \%$<smiles>CN1C(=O)C(=O)c2ccc([N+](=O)[O-])cc21</smiles>

16a: $54 \%$<smiles>CS(=O)(=O)N1C(=O)C(=O)c2cc([N+](=O)[O-])ccc21</smiles>

15b: $55 \%$<smiles>CN1C(=O)C(=O)c2cc([N+](=O)[O-])c([N+](=O)[O-])cc21</smiles>

16b: $0 \%$<smiles>CN1C(=O)C(=O)c2cc(F)c([N+](=O)[O-])cc21</smiles>

15d: $10 \%$

16d: $42 \%$<smiles>CCN1C(=O)C(=O)c2ccccc21</smiles>

15f: $14 \%$<smiles>CCN1C(=O)C(=O)c2ccc([N+](=O)[O-])cc21</smiles>

16f: $42 \%$

Scheme 9. Oxone $/ \mathrm{NaNO}_{2}$-promoted oxidative radical cyclization of the propylamide 14 
The proposed reaction mechanism involves an initial Oxone-promoted oxidation of $\mathrm{NaNO}_{2}$ to the $\bullet \mathrm{NO}$ radical species, under thermal condition. Thus, $\bullet \mathrm{NO}$ radical is oxidized in the presence of $\mathrm{O}_{2}$ to $\bullet \mathrm{NO}_{2}$, which is trapped by the $\mathrm{C} \equiv \mathrm{C}$ triple bond, to afford the intermediate $\mathbf{A}$. Following, a radical isomerization produces the intermediate $\mathbf{B}$, which is quickly converted by electron delocalization to the tertiary radical species $\mathbf{C}$, that undergoes an intramolecular radical annulation to produce the cyclized intermediate $\mathbf{D}$. A hydrogen radical elimination converts the aryl radical $\mathbf{D}$ to the intermediate $\mathbf{E}$, which after a decarbonylation, affords the intermediate $\mathbf{F}$. The intermediate $\mathbf{D}$ can also be trapped by 1 equivalent of $\bullet \mathrm{NO}_{2}$ radical to produce the intermediate $\mathbf{G}$, which is subsequently decarbonylated to generate the intermediate $\mathbf{H}$. Finally, the intermediates $\mathbf{F}$ and $\mathbf{H}$ are hydrolyzed and converted to the respective products 15 and 16 (Scheme 10).

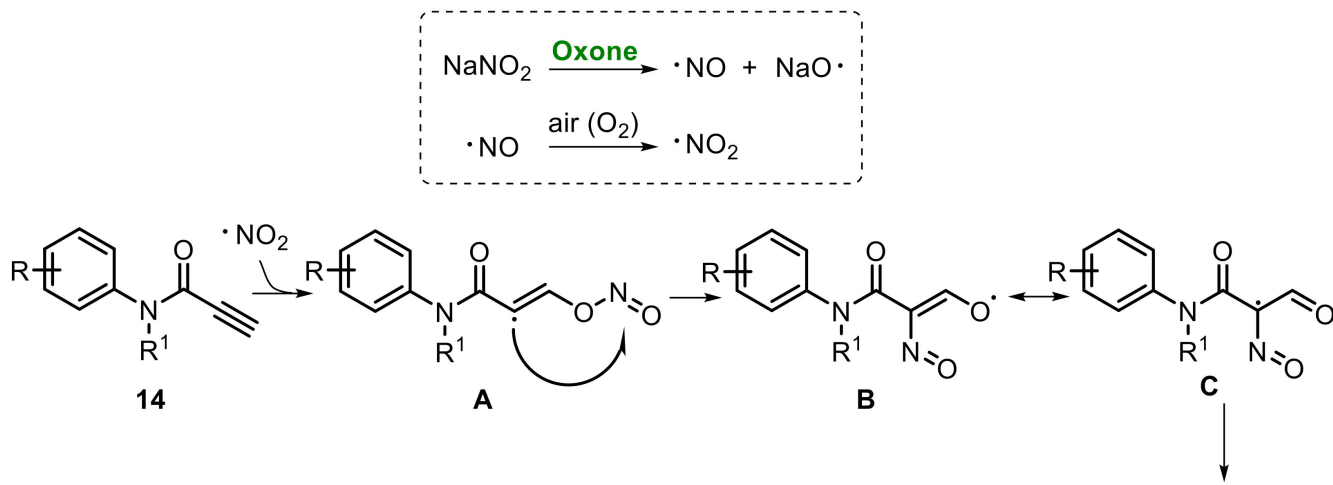<smiles>[R1]N1C(=O)C(=O)c2cc[R]cc21</smiles><smiles>CC(O)C1CCCCC1</smiles><smiles>O=c1[nH]c(=O)n([Tl])c2cc[R]cc12</smiles><smiles>C[C@H](O)[C@H](C)O</smiles><smiles>[R1]N1C(=O)C(N=O)(NO)c2cc[R17]cc21</smiles><smiles>[R1]N1C(=O)C(C)(N=O)C2c3ccc(C)cc3NC21</smiles>

15

$$
\text { E }
$$<smiles>[R]c1ccc2c(c1)N([R])C(=O)C2=O</smiles>

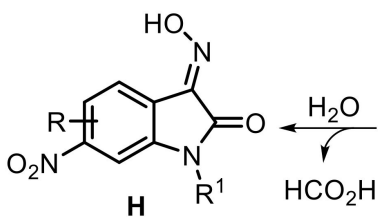<smiles>[R][X]c1ccc2c(c1)N([R])C(=O)C2(C)N=O</smiles>

Scheme 10. Reaction mechanism for the Oxone $/ \mathrm{NaNO}_{2}$-promoted oxidative annulation.

In 2019, Wei and co-workers reported an Oxone-mediated base-free radical bicyclization of 1,6-enynes 17, in the presence of ketones 18, affording several functionalized polycyclic $\gamma$-lactams 19 (Scheme 11) [21]. Under the optimal conditions, aliphatic ketones, such as acetone $\mathbf{1 8} \mathbf{a}$ and cyclobutanone $\mathbf{1 8 b}$, reacted satisfactorily with 1,6-enyne $\mathbf{1 7} \mathbf{a}$, yielding the respective products $19 a$ and $19 b$ in $82 \%$ and $56 \%$ yield, respectively. On the other hand, acetophenone $18 \mathrm{c}$ and ethyl acetate $18 \mathrm{~d}$ were not suitable substrates, which may be presumably attributed to the inertness of the $\alpha-\mathrm{Cs} p^{3}-\mathrm{H}$ bond to generate the corresponding $\alpha$-carbonyl radical species. Additionally, a range of 1,6-enynes were well tolerated as the substrate, giving the respective polycyclic $\gamma$-lactams $19 \mathbf{e}-\mathbf{i}$ at up to an $88 \%$ yield (Scheme 11). 
<smiles>[R]C(=C)C(=O)N([R])CC#C</smiles>

17<smiles>[R]C(=O)C([R])[2H]</smiles>

18

$\mathrm{R}, \mathrm{R}^{1}, \mathrm{R}^{3}=$ aryl, alkyl; $\mathrm{R}^{2}=\mathrm{H}$, alkyl

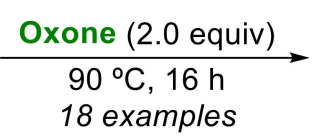

18 examples<smiles>[R]C(=C)C1([R])CC2C(C1)N([R])C(=O)C1([R])CCCCC21</smiles>

19

$37-88 \%$

d.r. $>20: 1$

\section{Selected examples}<smiles>CC(=O)C1CC2CN(c3ccccc3)C(=O)C2(C)C1</smiles>

19a: $82 \%$<smiles>CCCCN1CC2CC3(CCC3=O)CC2(C)C1=O</smiles>

19b: $56 \%$<smiles>[R]C(=O)C1CC2CN(CCCCCCCCCC)C(=O)C2(C)C1</smiles>

19c: $\mathrm{R}^{3}=\mathrm{C}_{6} \mathrm{H}_{5}$, trace 19d: $R^{3}=$ OEt, NR<smiles>[R]C(=O)C1CC2CN(c3ccc([R])cc3)C(=O)C2(C)C1</smiles>

19e: $\mathrm{R}=\mathrm{OMe}, 71 \%$

19f: $R=C_{3}, 88 \%$

19g: $\mathrm{R}={ }^{t} \mathrm{Bu}, 75 \%$<smiles>CC(=O)C1CC2CN(c3ccccc3)C(=O)C2(c2ccccc2)C1</smiles>

19h: $70 \%$<smiles>CC(=O)C1CC2CN(c3ccccc3)C(=O)C2C1</smiles>

19i: $37 \%$

Scheme 11. Oxone-mediated radical bicyclization of 1,6-enynes 17 and ketones 18.

The reaction mechanism to prepare the $\gamma$-lactams 19 is depicted in Scheme 12. Initially, the $\alpha$-carbonyl radical $\mathbf{A}$, which is formed after heating the ketone 18a in the presence of Oxone, is added to the terminal $C \equiv C$ double bond (of 1,6-enyne 17), giving the alkyl radical intermediate $\mathbf{B}$. After an intramolecular cyclization, the tertiary radical $\mathbf{B}$ is converted to the vinyl radical intermediate $\mathbf{C}$, which undergoes an 1,5- $\mathrm{H}$ shift, to be converted to the intermediate D. Finally, the second cyclization process takes place, generating the intermediate $\mathbf{E}$, that through a homolytic hydrogen abstraction is converted to the desired product 19.
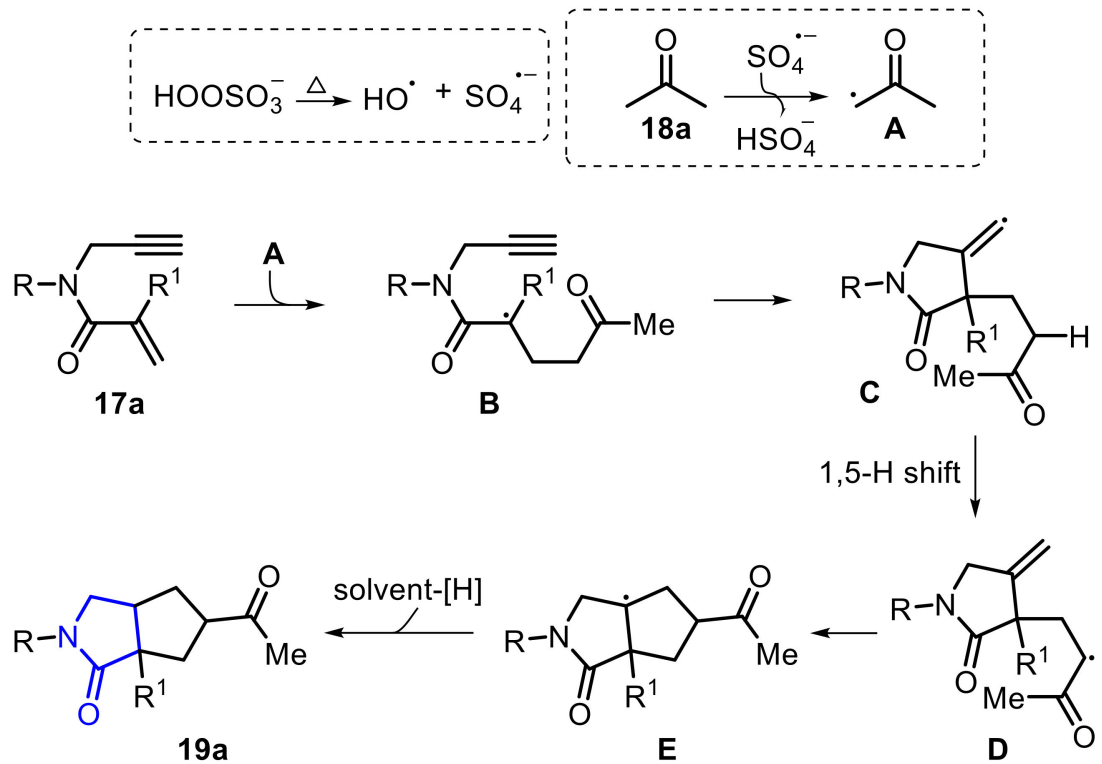

Scheme 12. Reaction mechanism for the Oxone-promoted bicyclization of 1,6-enynes 17. 
Additionally, in 2019, some of us reported the electrophilic cyclization of $\beta$-alkynyl hydrazones 20, promoted by the system Oxone/RSeSeR 21, to obtain 4-organoselanyl$1 H$-pyrazoles 22 (Scheme 13) [22]. The reaction scope was studied employing several substituted diorganyl diselenide $\mathbf{2 1}$ and hydrazones $\mathbf{2 0}$, affording the desired products 22 in poor to excellent yields. A limitation was faced when the $\alpha, \beta$-alkynyl hydrazone 20k, bearing an electron-deficient ring $\left(\mathrm{R}^{3}=2,4-\mathrm{F}_{2} \mathrm{C}_{6} \mathrm{H}_{3}\right)$, was employed as substrate, providing the product $22 \mathrm{k}$ at only a $40 \%$ yield after $24 \mathrm{~h}$. Better results were obtained when electronrich $\alpha, \beta$-alkynyl hydrazones $20\left(\mathrm{R}^{3}=3-\mathrm{MeC}_{6} \mathrm{H}_{4}\right.$ and $\left.2,4-\mathrm{Me}_{2} \mathrm{C}_{6} \mathrm{H}_{3}\right)$ were reacted, yielding the products $22 \mathbf{i}$ and $\mathbf{2 2} \mathbf{j}$ at $97 \%$, after 11 and $8 \mathrm{~h}$ of reaction, respectively (Scheme 13 ).

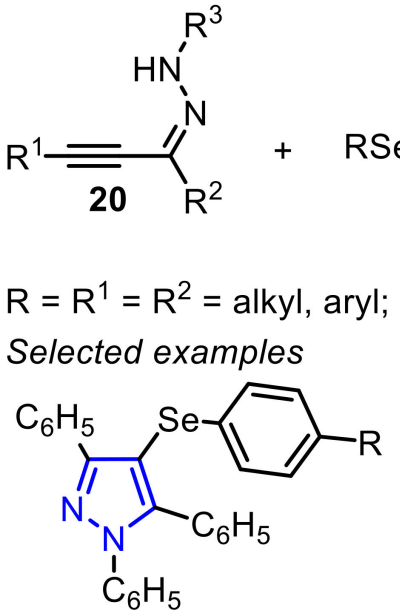

22a: $\mathrm{R}=\mathrm{H}, 93 \%, 4 \mathrm{~h}$

22b: $\mathrm{R}=4-\mathrm{Me}, 85 \%, 5 \mathrm{~h}$

22c: $\mathrm{R}=4-\mathrm{OMe}, 90 \%, 3 \mathrm{~h}$

22d: $\mathrm{R}=4-\mathrm{Cl}, 87 \%, 4.5 \mathrm{~h}$

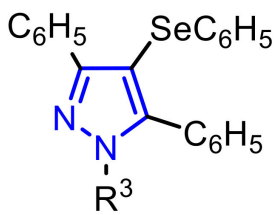

22i: $\mathrm{R}^{3}=3-\mathrm{MeC}_{6} \mathrm{H}_{4}, 97 \%, 11 \mathrm{~h}$

22j: $\mathrm{R}^{3}=2,4-\mathrm{MeC}_{6} \mathrm{H}_{3}, 97 \%, 8 \mathrm{~h}$

22k: $\mathrm{R}^{3}=2,4-\mathrm{FC}_{6} \mathrm{H}_{3}, 40 \%, 24 \mathrm{~h}$

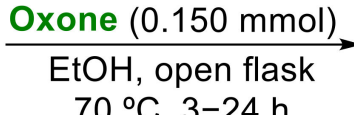

$70^{\circ} \mathrm{C}, 3-24 \mathrm{~h}$

17 examples<smiles>[R][Se]c1c([R])nn([R])c1[R]</smiles>

22

$40-97 \%$<smiles>[R15]c1ccc(-c2c([R16])c([AsH2])nn2CCCC)cc1</smiles>

22e: $\mathrm{R}^{1}=4-\mathrm{Me}, 92 \%, 4 \mathrm{~h}$

22f: $\mathrm{R}=4-\mathrm{Cl}, 95 \%, 8 \mathrm{~h}$

22g: $\mathrm{R}=\mathrm{C}_{4} \mathrm{H}_{9}, 84 \%, 3 \mathrm{~h}$

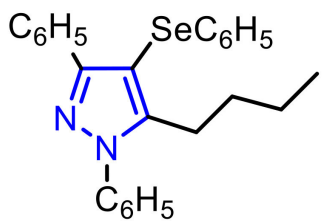

22I: $84 \%, 3 \mathrm{~h}$

22n: $\mathrm{R}^{2}=4-\mathrm{ClC}_{6} \mathrm{H}_{4}, 95 \%, 8 \mathrm{~h}$

Scheme 13. Oxone/RSeSeR-promoted electrophilic cyclization of $\alpha, \beta$-alkynyl hydrazones 20 .

During control experiments, the in situ generation of Se-based electrophilic species was identified by ${ }^{77}$ Se NMR and HRMS, which were the key intermediates to disclose the annulation pathway. The proposed mechanism starts with a SET from diphenyl diselenide 21 to the $\mathrm{HSO}_{5}{ }^{-}$species, followed by the cleavage of the Se-Se bond, providing the Se-based electrophiles $\mathrm{PhSeOSO}_{3}{ }^{-} \mathrm{I}$ and $\mathrm{PhSeOH}$ II, which promote the electrophilic annulation of the $\alpha, \beta$-alkynyl hydrazone $\mathbf{2 0}$, to afford the desired products $\mathbf{2 2}$. It is worth to mention that species I and II, in the presence of $\mathrm{MeOH}$ and Oxone, can be converted to the methyl benzeneseleninate $\mathbf{V}$ and benzeneseleninic acid VI, respectively (Scheme 14). 


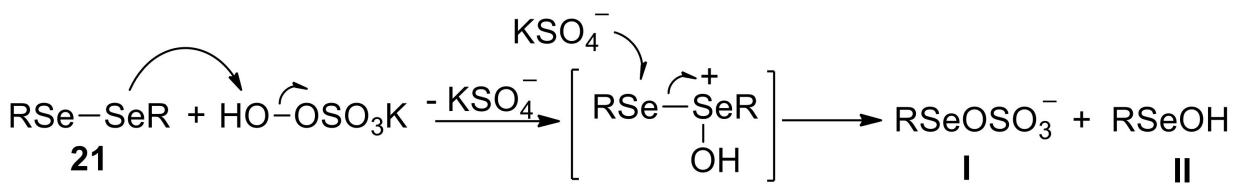

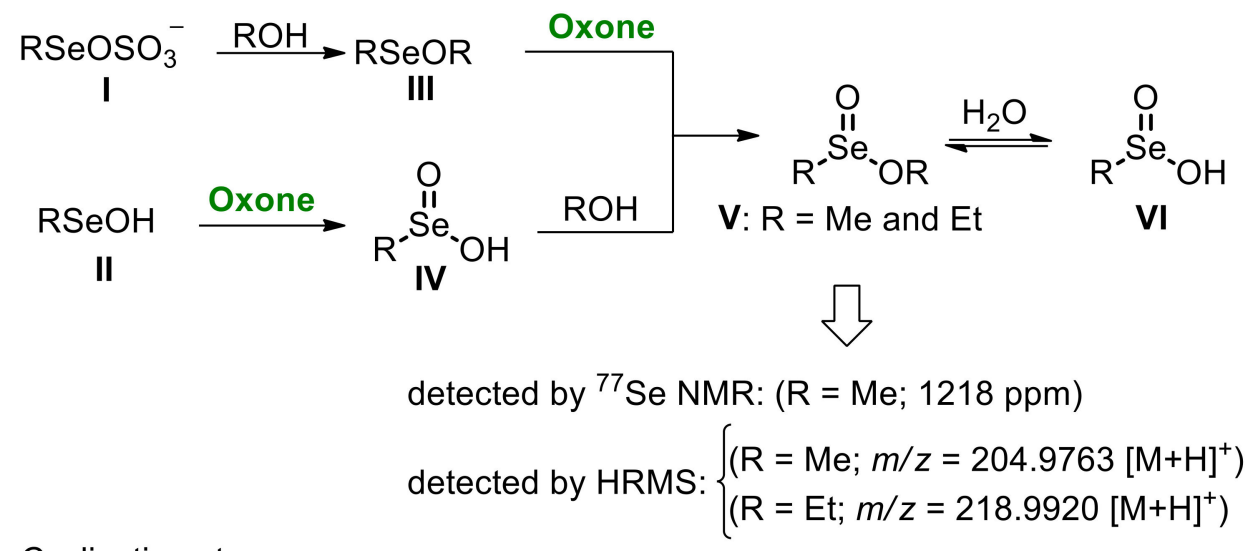

Cyclization step:

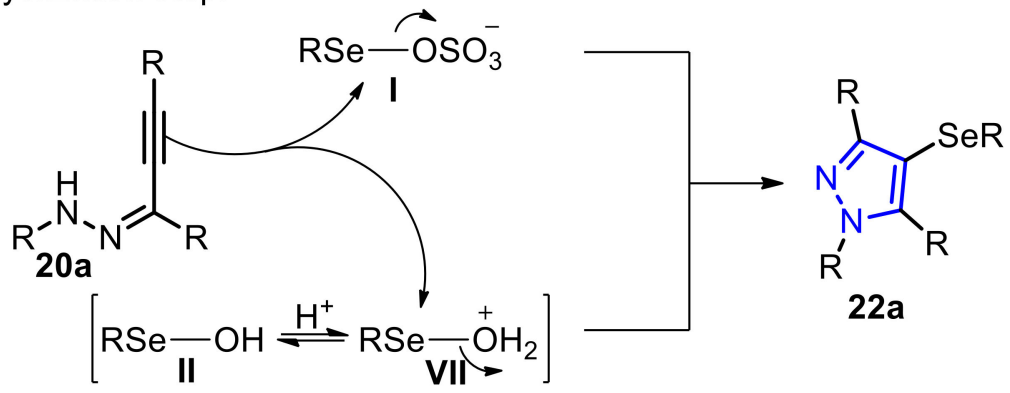

Scheme 14. Reaction mechanism for the Oxone/RSeSeR-promoted electrophilic cyclization of $\alpha, \beta$ alkynyl hydrazones 20.

In the same year, Jacob and co-workers also reported the synthesis of 4-organoselanyl$1 \mathrm{H}$-pyrazoles 22 through a multicomponent reaction between hydrazines 23, 1,3-diketones 24 and diorganyl diselenides 21, in the presence of Oxone (Scheme 15) [23]. In general, the protocol presented a good substrate tolerance, allowing the synthesis of twelve substituted 4-organylselanylpyrazoles 22 in moderate to excellent yields, after short reaction times. When the unsymmetrical 1-phenyl-1,3-butanedione 24c was employed as substrate, two regioisomers $\mathbf{2 2 q}$ and $\mathbf{2 2} \mathbf{q}^{\prime}$ in a $\mathbf{9 6 : 4}$ ratio were obtained at $89 \%$ yield. Authors attributed the high selectivity to the steric hinderance of ketone $24 \mathrm{c}$ and also to the conjugative effect of the aromatic ring, that can contribute to stabilize the enol tautomer, increasing the regioselectivity of this cyclization towards the formation of product 22q. The reactivity of $\mathrm{N}$-aryl hydrazines $\mathbf{2 3}$ was affected by electronic effect. The electron-rich system $(\mathrm{R}=\mathrm{Me})$ afforded the respective product $22 \mathrm{r}$, at $69 \%$ yield, whereas the electron-deficient one $(\mathrm{R}=\mathrm{Cl})$ gave 22s at $44 \%$ yield, requiring a temperature increase from $50{ }^{\circ} \mathrm{C}$ to $100{ }^{\circ} \mathrm{C}$. However, despite this significant difference, in comparison with the absence of substituents (product 22o), the reaction efficiency was remarkably decreased. On the other hand, the results suggest that the process is not sensitive to the electronic effect in the diaryl diselenides 21, and the products $\mathbf{2 2} \mathbf{u}-\mathbf{x}$ were obtained in good to excellent yields. Additionally, dibutyl and 2,2'-dipyridyl diselenides 21 reacted smoothly to produce the products $22 \mathrm{y}$ and $22 \mathbf{z}$ at a $90 \%$ and $58 \%$ yield, respectively (Scheme 15). 


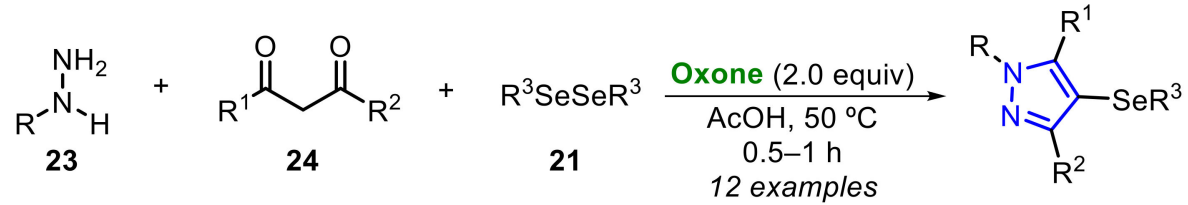

22 $44-98 \%$<smiles>[R]c1nn(-c2ccccc2)c([R])c1[SeH]</smiles>

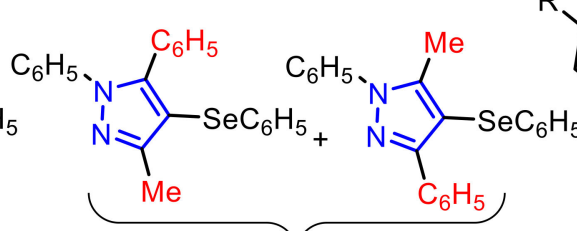

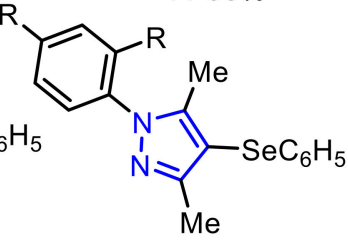

22o: $R^{1}, R^{2}=M e, 98 \%, 0.5 \mathrm{~h}$

22p: $R^{1}, R^{2}=E t, 90 \%, 0.5 \mathrm{~h}$

22q/q' (96:4): $89 \%, 0.5 \mathrm{~h}$

22r: $R=M e, 69 \%, 1 \mathrm{~h}$

$$
\text { 22p: } R^{1}, R^{2}=E t, 90 \%, 0.5 h
$$

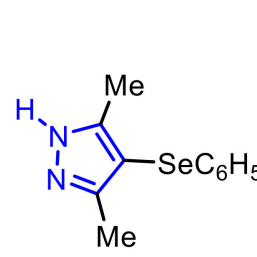

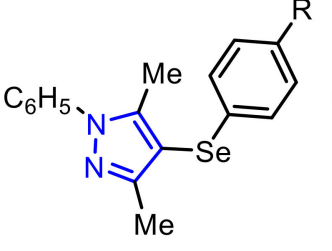<smiles>C[As]c1c(C)nn(-c2ccccc2)c1C</smiles><smiles>Cc1nn(-c2ccccc2)c(C)c1[Se]c1ccccn1</smiles>

22t: $75 \%, 1 h^{*}$

22u: $\mathrm{R}=\mathrm{Me}, 77 \%, 0.5 \mathrm{~h}$

22v: $\mathrm{R}=\mathrm{OMe}, 84 \%, 0.5 \mathrm{~h}$

22w: $\mathrm{R}=\mathrm{Cl}, 81 \%, 0.5 \mathrm{~h}$

22x: $R=F, 90 \%, 0.5 \mathrm{~h}$

22y: $90 \%, 0.5 \mathrm{~h}$

22z: $58 \%, 0.5 \mathrm{~h}$

${ }^{*}$ Reaction carried out at $100^{\circ} \mathrm{C}$.

Scheme 15. Oxone-mediated multicomponent synthesis of substituted 4-organylselanylpyrazoles 22.

Still in 2019, Muthukrishnan and co-workers reported an Oxone-promoted intramolecular dehydrogenative Povarov cyclization of alkyne tethered $N$-aryl glycine esters and amides 25 (Scheme 16) [24]. Under the optimal conditions (Oxone (1.1 equiv), $\mathrm{Cu}(\mathrm{OTf})_{2}$ $(5 \mathrm{~mol} \%)$ in $\mathrm{MeCN}$ at room temperature or $60^{\circ} \mathrm{C}$ for $12 \mathrm{~h}$ ), a library of thirty-eight functionalized quinoline-fused lactones and lactams $\mathbf{2 6}$ were accessed at up to $88 \%$ yield.<smiles>[R1]C#CC[X]C(=O)CNc1ccc([R])cc1</smiles>

25

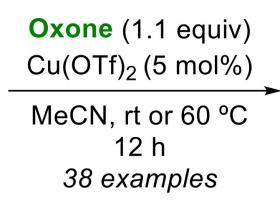

38 examples<smiles>[R]c1ccc2nc3c(c([R])c2c1)CC[Y]3=O</smiles>

$\mathrm{X}=\mathrm{O}, \mathrm{NPh}, \mathrm{NBn} ; \mathrm{R}=\mathrm{Me},{ }^{i} \mathrm{Pr},{ }^{t} \mathrm{Bu}, \mathrm{OH}, \mathrm{OMe}$,

$\mathrm{OPh}, \mathrm{F}, \mathrm{Cl}, \mathrm{Br} \mathrm{CN} ; \mathrm{R}^{1}=$ aryl, alkyl, heteroaryl<smiles>[R]c1ccc2nc3c(c(C)c2c1)COC3=C</smiles>

26a: $\mathrm{R}=\mathrm{Me}, 88 \% \mathrm{O}$

26b: $\mathrm{R}=\mathrm{OH}, 57 \%$

26c: $R=F, 79 \%$

26d: $\mathrm{R}=\mathrm{Cl}, 76 \%$<smiles>COc1ccc2nc3c(c([N+](=O)[O-])c2c1)COC3=O</smiles>

26g: $17 \%$<smiles>COc1ccccc1-c1c2c(nc3ccc(C(C)(C)C)cc13)C(=O)OC2</smiles>

26e: $56 \%$<smiles>[R]c1ccc2nc3c(c(CCCCC)c2c1)CN(C)C3=O</smiles><smiles>CC(C)c1ccc2nc3c(c(-c4cccs4)c2c1)COC3=O</smiles>

26f: $77 \%$<smiles>Cc1ccc2nc3c(c(-c4cccs4)c2c1)CN(Cc1ccccc1)C3=O</smiles>

26k: $73 \%$

Scheme 16. Oxone-promoted intramolecular dehydrogenative Povarov cyclization. 
This methodology was used to construct complex structures, such as the antibiotic Uncialamycin $26 \mathbf{1}$ (Scheme 17A). Moreover, the synthesized products $\mathbf{2 6 \mathbf { h }}$ and $\mathbf{2 6 \mathbf { i }}$ were easily converted to $\mathbf{2 6} \mathbf{m}$ and $\mathbf{2 6 n}$, which are analogues of the cytotoxic alkaloid Luotonin A (Scheme 17B).

- Construction of Bioactive Compounds

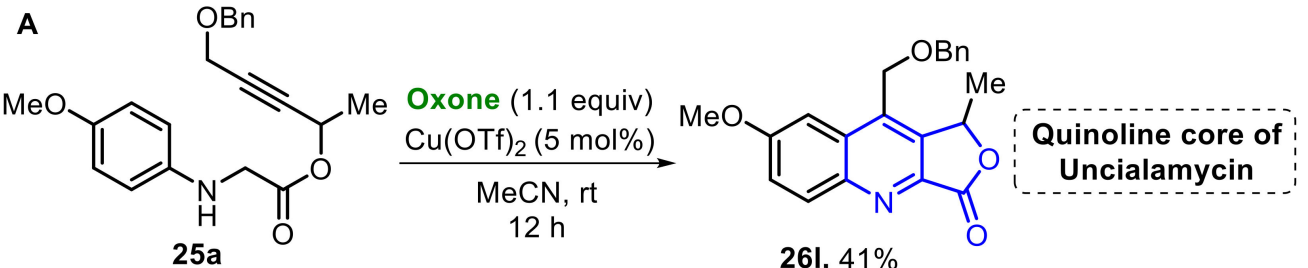

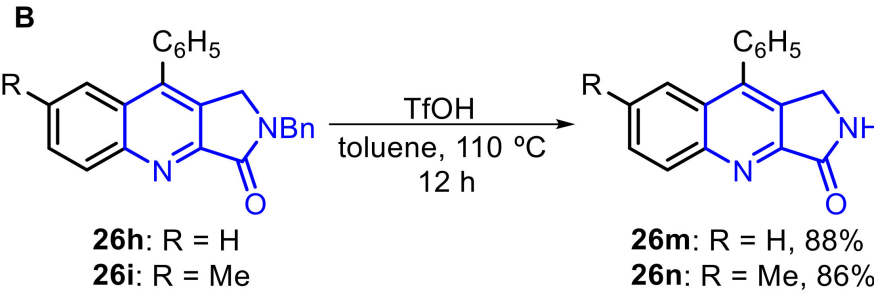

Scheme 17. Synthetic application to construct complex structures, such as (A) the antibiotic Uncialamycin 261 and (B) the analogues of the cytotoxic alkaloid Luotonin A 26m and 26n.

Liu, Qiu, and co-workers reported the $\mathrm{ZnBr}_{2} /$ Oxone-mediated radical ipso-cyclization of N-(3-arylprop-2-yn-1-yl)aniline 27 to prepare 1-azaspiro[4.5]deca-3,6,9-trien-8-ones 28 (Scheme 18) [25]. The reactions were carried out in the presence of $\mathrm{ZnBr}_{2}$ (1 equiv), Oxone (2 equiv) and a mixture of acetonitrile and $\mathrm{H}_{2} \mathrm{O}(v / v=4: 1)$ as solvent at room temperature. In general, electron-rich and electron-deficient aryl groups attached to the $\mathrm{Csp}-\mathrm{Csp}$ bond $\left(\mathrm{R}=\mathrm{CN}, \mathrm{Me}, \mathrm{COMe}\right.$ and $\left.\mathrm{CO}_{2} \mathrm{Me}\right)$ were well tolerated under the optimized condition, affording the products $\mathbf{2 8 a}-\mathbf{d}$ in good yields. However, limitations were faced by employing the 2-iodo- $N$-tosyl- $N$-(but-2-yn-1-yl)aniline 27e as substrate, and the product 28e was observed only in trace amounts. Regarding the pendent $N$-aryl group, the presence of both electron donor and electron withdrawing substituents $(\mathrm{R}=\mathrm{Me}$ and $\mathrm{Cl})$ and $\left(\mathrm{R}^{1}=\mathrm{Me}\right.$ and $\mathrm{Br}$ ) were tolerated, affording the products $\mathbf{2 8 g} \mathbf{- j}$ in good yields. A good result was obtained when the $N$-protecting group $\mathrm{R}^{2}=4-\mathrm{BrC}_{6} \mathrm{H}_{4}$ was used, and product 28k was obtained at a $72 \%$ yield (Scheme 18).

Zhou and co-workers reported an Oxone/TBAB-mediated oxidative regioselective cyclization of $N$-aryl-2-arylbenzamides 29 to prepare spiro[cyclohexane-1,1'-isoindoline]2,5-diene-3',4-diones 30 (Scheme 19) [26]. A total of five para-substituted benzamides 29 $\left(\mathrm{R}=\mathrm{Cl}, \mathrm{Br}, \mathrm{CN}, \mathrm{CF}_{3}, \mathrm{CO}_{2} \mathrm{Me}\right.$ ) were employed as substrate, affording the respective products 30a-e in moderate to good yields.

In the absence of a substituent at the para-position of the $N$-aryl-2-phenylbenzamide 29, the bromination of this position occurred, and the product 31a was afforded in $75 \%$ yield. Considering the synthetic versatility of the aryl bromide core, the authors expanded the reaction scope to prepare several brominated products 31 in moderate to good yields (Scheme 20). Interestingly, the presence of a methoxy group in the ortho-phenyl ring $\left(\mathrm{R}^{2}=3-\mathrm{OMe}\right)$ caused the formation of the dibrominated product 310 at a $52 \%$ yield.

An Oxone/TBAB-mediated synthesis of 3-bromo-1,2-dihydroquinoline derivatives 32 through a radical 6-endo-trig ortho-cyclization of 2-alkynylbenzamide 33 was described in 2019 by Liu and co-workers (Scheme 21) [27]. Several substituted $N$-alkynyl-benzenesulfonamides 33 were used under optimal conditions, giving a range of dihydroquinoline derivatives 32 in moderate to good yields. 2-Alkynylbenzamides containing electron-rich benzene ring $\left(\mathrm{R}^{2}=\mathrm{Me}\right.$ and $\left.\mathrm{OMe}\right)$ attached to the alkynyl portion were satisfactorily employed as substrate. Among them, the steric hindrance promoted by the methyl group (ortho-, meta- or para-position) slightly affected the reaction efficiency, giving the products $\mathbf{3 2} \mathbf{b}-\mathbf{d}$ in similar 
yields. On the other hand, the presence of the methoxy group at the para-position activated the alkynyl portion, affording the product $32 \mathrm{e}$ at a $75 \%$ yield, remarkably increasing the reaction efficiency. The protocol presented an interesting halogen tolerance, affording the desired products $32 \mathrm{f}(\mathrm{R}=4-\mathrm{F})$ and $32 \mathrm{~g}(\mathrm{R}=4-\mathrm{Cl})$ at $71 \%$ and $68 \%$, respectively. Heteroareneand alkyl-substituted alkynylbenzamides $\left(\mathrm{R}^{2}=2\right.$-thienyl and Me), as well as $\mathrm{N}$-mesyl, were suitable substrates, affording the respective products $32 \mathbf{h}, \mathbf{3 2} \mathbf{i}$ and $32 \mathbf{j}$ at $67 \%, 72 \%$ and $56 \%$ yields (Scheme 21 ).<smiles>[R]C#CCN(c1ccccc1[R])S([R])(=O)=O</smiles>

27

$\mathrm{R}=\mathrm{H}, \mathrm{Me}, \mathrm{Cl} ; \mathrm{R}^{1}=\mathrm{Me}, \mathrm{Br}$, I

$\mathrm{R}^{2}=$ aryl, heteroaryl; $\mathrm{R}^{3}=$ aryl

\section{Selected examples}<smiles>[R]c1ccc(C2=C(Br)CN([As])C23C=CC(=O)C=C3I)cc1</smiles>

28a: $R=C N, 72 \%$

28b: $\mathrm{R}=\mathrm{Me}, 77 \%$

28c: $R=$ COMe, $70 \%$

28d: $\mathrm{R}=\mathrm{CO}_{2} \mathrm{Me}, 81 \%$

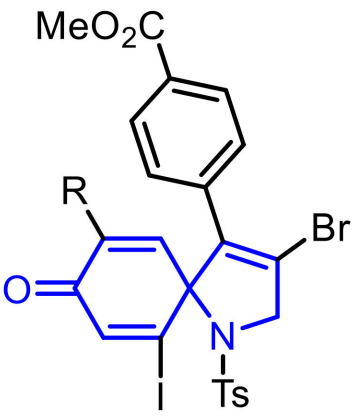

28g: $\mathrm{R}=\mathrm{Me}, 65 \%$

28h: $\mathrm{R}=\mathrm{Cl}, 62 \%$<smiles>CC1=C(Br)CN([AsH])C12C=CC(=O)C=C2I</smiles>

28e: trace<smiles>[R]C1=CC(=O)C=CC12C(c1ccc(C(OC)OC)cc1)=C(Br)CN2[Y5]</smiles>

28i: $R^{1}=B r, 75 \%$

28j $R^{1}=M e, 68 \%$<smiles>[R]CC12C([R])=CC(=O)C([R])=C1C(Br)=C([R])N2S([R])(=O)=O</smiles>

28

$50-81 \%$<smiles>COC(=O)c1ccc(C2=C(Br)CN([As])C23C=CC(=O)C(Cl)=C3I)cc1</smiles>

28f: $50 \%$<smiles>COC(=O)c1ccc(C2=C(Br)CN(S(=O)(=O)c3ccc(Br)cc3)C23C=CC(=O)C=C3I)cc1</smiles>

Scheme 18. $\mathrm{ZnBr}_{2}$ /Oxone-mediated radical ipso-cyclization of alkynyl anilines 27. 
<smiles>[R]c1ccc(NC(=O)c2ccccc2-c2ccccc2)cc1</smiles>

TBAB (2.0 equiv) Oxone (5.0 equiv) DCE: $\mathrm{H}_{2} \mathrm{O}(\mathrm{v} / \mathrm{v}=1: 1)$ $80^{\circ} \mathrm{C}$, overnight 5 examples<smiles>[R]c1ccc(N2C(=O)c3ccccc3C23C=CC(=O)C=C3)cc1</smiles><smiles>O=C1C=CC2(C=C1)c1ccccc1CN2c1ccc(F)cc1</smiles>

30a: $\mathrm{R}=4-\mathrm{Cl}, 80 \%$ 30b: $\mathrm{R}=4-\mathrm{Br}, 78 \%$ 30c: $R=4-C N, 66 \%$ 30d: $R=4-\mathrm{CF}_{3}, 56 \%$<smiles>C=CC1(C)c2ccccc2CN1c1ccc(C(=O)OC)cc1</smiles>

30e: $63 \%$

Scheme 19. Oxone/TBAB-mediated oxidative cyclization of $N$-aryl-2-arylbenzamides 29.<smiles>[R][R]c1ccc(NC(=O)c2cc[R]#cc2-c2ccccc2)cc1</smiles>

$\mathrm{R}=\mathrm{H}$, 4-Cl, 4-Me, 5-Me, 5-OMe, 5-Br, 5-Cl, 5-F $\mathrm{R}^{1}=\mathrm{H}, 2-\mathrm{Br}, 3-\mathrm{F}, 2-\mathrm{Me}, 3-\mathrm{Me} ; \mathrm{R}^{2}=\mathrm{H}, \mathrm{F}, \mathrm{Me}$<smiles>O=C1C=CC2(C=C1)c1ccccc1CN2c1ccc(Br)cc1</smiles>

31a: $75 \%$<smiles>[R]=C1C=CC2=C(C=C1)C1(C=CC(=O)C=C1)N(c1ccc(Br)cc1)C2</smiles><smiles>[R]C1=CC2(C=CC1=O)c1ccccc1CN2c1ccc(Br)cc1</smiles>

31m: $R^{2}=F, 42 \%$ 31n: $R^{2}=M e, 55 \%$

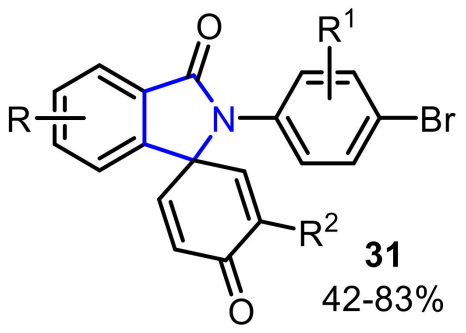

31b: $\mathrm{R}=4-\mathrm{Cl}, 68 \%$

31c: $R=5-B r, 54 \%$

31d: $R=5-\mathrm{Cl}, 77 \%$

31e: $R=5-F, 70 \%$

31f: $R=4-M e, 55 \%$

31g: $R=5-\mathrm{Me}, 62 \%$

31h: $\mathrm{R}=5-\mathrm{OMe}, 56 \%$<smiles>[R]CC(C)(C)c1ccc(Br)cc1N1Cc2ccccc2C12C=CC(=O)C=C2</smiles>

31i: $R^{1}=3-F, 62 \%$

$31 \mathrm{j}: \mathrm{R}^{1}=2-\mathrm{Br}, 45 \%$

$31 \mathrm{k}: \mathrm{R}^{1}=2-\mathrm{Me}, 83 \%$

31I: $R^{1}=3-\mathrm{Me}, 50 \%$<smiles>COC1=CC2(C(Br)=CC1=O)c1ccccc1CN2c1ccc(Br)cc1</smiles>

310: $52 \%$

Scheme 20. Oxone/TBAB-mediated synthesis of brominated products $\mathbf{3 1}$. 


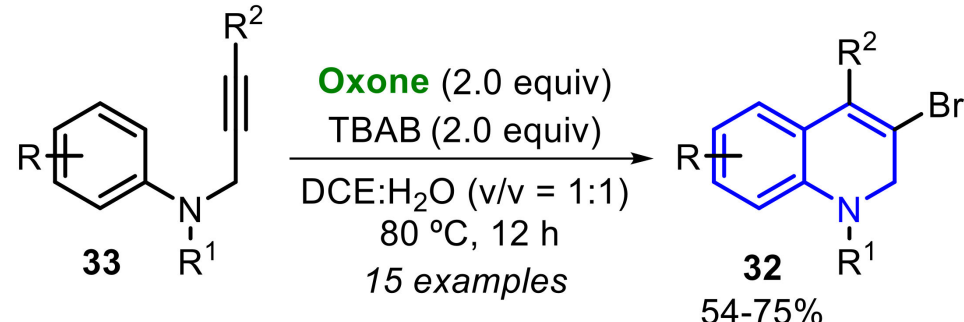

$\mathrm{R}=\mathrm{H}, \mathrm{Me} ; \mathrm{R}^{1}=$ tosyl, mesyl

$54-75 \%$

$\mathrm{R}^{2}=$ aryl, alkyl, heteroaryl

\section{Selected examples}<smiles>BrC1=C(c2ccccc2)c2ccccc2N([125I])C1</smiles>

32a, $64 \%$<smiles>BrC1=C(c2cccs2)c2ccccc2N([125I])C1</smiles>

32h, $67 \%$<smiles>[R]c1ccc(C2=C(Br)CN([Y5])c3ccccc32)cc1</smiles>

32b: $R=2-M e, 54 \%$

32c: $\mathrm{R}=3-\mathrm{Me}, 58 \%$

32d: $\mathrm{R}=4-\mathrm{Me}, 59 \%$

32e: $R=4-O M e, 75 \%$

32f: $R=4-F, 71 \%$

32g: $\mathrm{R}=4-\mathrm{Cl}, 68 \%$<smiles>CC1=C(Br)CN([AsH])c2ccccc21</smiles>

$32 \mathbf{i}, 72 \%$<smiles>CS(=O)(=O)N1CC(Br)=C(c2ccccc2)c2ccccc21</smiles>

$32 \mathrm{j}, 56 \%$

Scheme 21. Oxone/TBAB-mediated synthesis of 3-bromo-1,2-dihydroquinoline derivatives 32.

Based on control experiments, a plausible reaction mechanism was proposed, which starts with an Oxone-promoted oxidation of bromide anion $\left(\mathrm{Br}^{-}\right)$to the bromo radical species $(\mathrm{Br} \bullet$ ) through a SET process. Following on from this, a radical addition of the bromo radical to the substrate 33 produces the intermediate $\mathbf{A}$, which undergoes a radical 6-endotrig cyclization, to be converted to the intermediate $\mathbf{B}$. Finally, the intermediate $\mathbf{B}$ undergoes oxidation, followed by a deprotonation, to be converted to the desired dihydroquinoline 32 (Scheme 22).

In 2020, Qiu and co-workers described an Oxone/TBAX-promoted $(X=\mathrm{Br}$ or I) tandem annulative radical halogenation of alkynyl imines 34 to access 3-haloquinolines 35 regioselectively (Scheme 23) [28]. Comparing TBAB and TBAI acting as the halogen-source, any remarkable difference in the reaction efficiency was observed, with TBAB affording 3-bromoquinolines 35 and TBAI delivering 3-iodoquinolines 35 in good to very good yields.

The reaction mechanism initiates with the Oxone-promoted oxidation of the halogen ion $\left(\mathrm{X}^{-}\right)$to the halogen radical species $(\mathrm{X} \bullet)$, that is subsequently added to the $\mathrm{C} \equiv \mathrm{C}$ bond, to produce the vinyl radical intermediate $\mathbf{A}$. In the sequence, the cyclized intermediate $\mathbf{B}$ is obtained via a 6-endo-trig cyclization, followed by the oxidation to the intermediate $\mathbf{C}$, which is finally aromatized to the product 35 (Scheme 24).

In the same year, Wei, Liu, Lei and co-workers reported an Oxone $/ \mathrm{Cu}\left(\mathrm{NO}_{3}\right)_{2}$-promoted radical annulative nitration of 1,6-enynes 17 (Scheme 25) [29]. Under the optimized reaction conditions, several $\mathrm{N}$-substituted 1,6-enynes 17, bearing different functional groups in the alkynyl and alkenyl portions, reacted satisfactorily to produce nitro-containing pyrrolidin-2-ones 36 in good to excellent yields. It is worth to mention that the protocol 
was satisfactorily scalable to $10 \mathrm{mmol}$, affording 3-methyl-4-methylene-3-(nitromethyl)-1phenylpyrrolidin-2-one 36 a at a $82 \%$ yield.

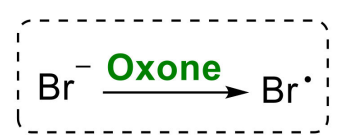<smiles>[R]C=C(Br)CN([R])c1ccccc1</smiles><smiles></smiles><smiles>[R]C#CCN([R])c1ccccc1</smiles>

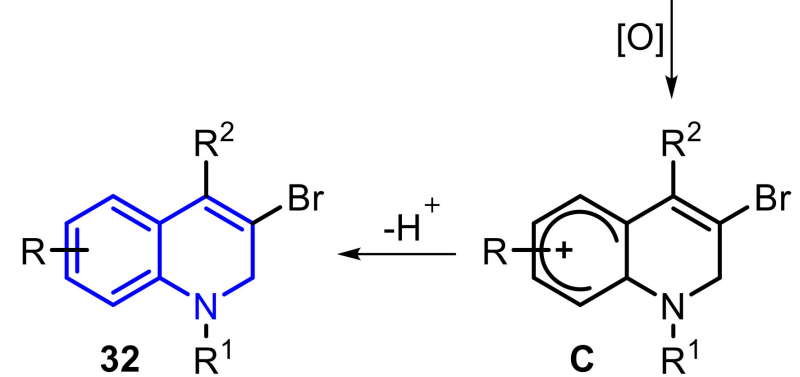

Scheme 22. Plausible mechanism for the radical 6-endo-trig cyclization of the substrate 33.<smiles>[R]C#CC([R])=Nc1[R]cccc1</smiles>

34

TBAB or TBAI (2.0 equiv)

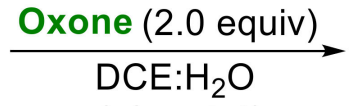

$(\mathrm{v} / \mathrm{v}=1: 1)$

$80^{\circ} \mathrm{C}, 8 \mathrm{~h}$ 23 examples<smiles>[R]c1nc2ccccc2c([R])c1[X]</smiles>

35

$63-85 \%$

$\mathrm{R}=4-\mathrm{Et}, 4^{\mathrm{t}} \mathrm{Bu}, 4-\mathrm{Me}, 4-\mathrm{F} ; \mathrm{R}^{1}=\mathrm{C}_{6} \mathrm{H}_{5}$, 4-OBn, 4- $\mathrm{ClC}_{6} \mathrm{H}_{4}$ $\mathrm{R}^{2}=2-\mathrm{ClC}_{6} \mathrm{H}_{4}, 3-\mathrm{ClC}_{6} \mathrm{H}_{4}, 4-\mathrm{ClC}_{6} \mathrm{H}_{4}, 4-\mathrm{FC}_{6} \mathrm{H}_{4}, 4-\mathrm{OCH}_{3} \mathrm{C}_{6} \mathrm{H}_{4}$ $\mathrm{Y}=\mathrm{Br}, \mathrm{I}$

\section{Selected examples}<smiles>CCCCCc1c(Br)c(-c2ccc(C)cc2)nc2ccccc12</smiles>

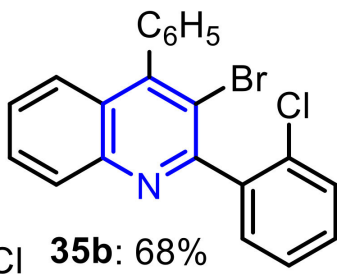<smiles>CC(C)C(C)(C)C</smiles>

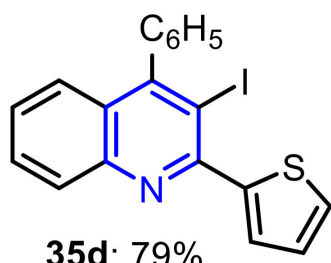<smiles>CC(C)(C)c1nc2ccccc2c(C2CC2)c1I</smiles><smiles>CC(C)(C)OC(=O)c1ccc2ccccc2c1C1CC1</smiles>

Scheme 23. Oxone/TBAX-promoted tandem annulative radical halogenation of alkynyl imines. 


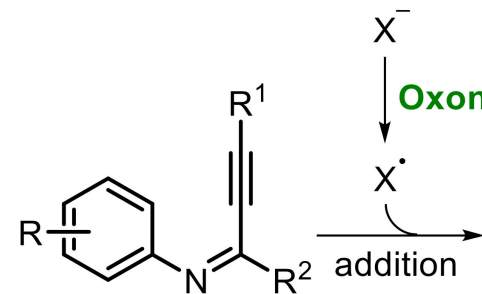

34

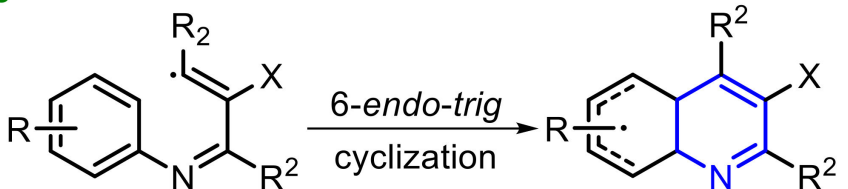

A
B<smiles>[R]Cc1cccc2nc([R])c([X])c([R])c12</smiles>

35<smiles></smiles>

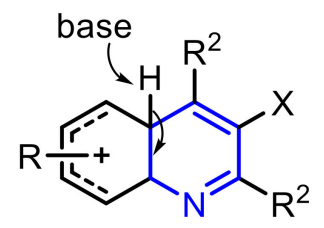

C

Scheme 24. Reaction mechanism for the Oxone/TBAX-promoted tandem annulative radical halogenation.<smiles>[R]C#CCN([R])C(=O)C([R])=C</smiles>

17
Oxone (1.2 equiv)

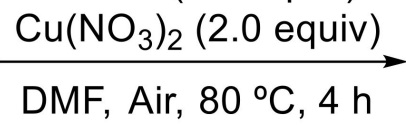
15 examples

$\mathrm{R}=$ aryl, alkyl; $\mathrm{R}^{1}=\mathrm{H}, \mathrm{Me}, \mathrm{C}_{6} \mathrm{H}_{5}$

$\mathrm{R}^{2}=\mathrm{Me}, \mathrm{C}_{6} \mathrm{H}_{5}, \mathrm{Bn}$

\section{Selected Examples}<smiles>C=C1CN(c2ccccc2)C(=O)C1(C)C[N+](=O)[O-]</smiles>

36a: $95 \%$<smiles></smiles>

36g: $\mathrm{R}=\mathrm{Bn}, 70 \%$

36h: $R=$ Ts, $75 \%$<smiles>[R]c1ccc(N2CC(=C)C(C)(C[N+](=O)[O-])C2=O)cc1</smiles><smiles>CC1(C[N+](=O)[O-])C(=O)N(c2ccccc2)CC1=Cc1ccccc1</smiles>

36i: NR<smiles>[R]C=C1CN([R])C(=O)C1([R])C[N+](=O)[O-]</smiles>

36

Scheme 25. Oxone/ $\mathrm{Cu}\left(\mathrm{NO}_{3}\right)_{2}$-promoted radical annulative nitration of 1,6-enynes 17.

Qiu, Shan, Chen and co-workers also reported a protocol based on the generation of halogen radical species $(\mathrm{X} \bullet)$, employing the system Oxone/TBAX $(\mathrm{X}=\mathrm{Br}$ and I), which disclosed the radical annulation of para-methoxyl alkynyl- $N$-phenylimines 37 , to access 3-halospirocyclohexadienones 38 (Scheme 26) [30]. Instead of the expected 6-endo-trig cyclization (Scheme 24), a radical 5-exo-trig cyclization occurred, disclosing a dearomative aza-spirocyclization, driving to the spirocyclic system 38. Through an optimization study, 
the best reaction condition was set reacting the substrate 36 in DCE: $\mathrm{H}_{2} \mathrm{O}(v / v=1: 1)$, at $80{ }^{\circ} \mathrm{C}$ for $8 \mathrm{~h}$, in the presence of Oxone (2.0 equiv) and TBAB or TBAI (2.0 equiv). In general, several para-methoxyl alkynyl- $N$-phenylimines 37 were satisfactorily submitted to the optimized reaction conditions, tolerating a wide range of substituents, including aryl systems bearing electron-donating and -withdrawing groups, heteroaryl and alkyl (Scheme 26).<smiles>[R]C#CC([R])=Nc1ccc(OC)cc1</smiles>

$\mathrm{X}=\mathrm{Br}, \mathrm{I} ; \mathrm{R}, \mathrm{R}^{1}=$ aryl, alkyl, heteroaryl<smiles>[R]C1=NC2(C=CC(=O)C=C2)C([R])C1[X]</smiles>

38

\section{Selected examples}

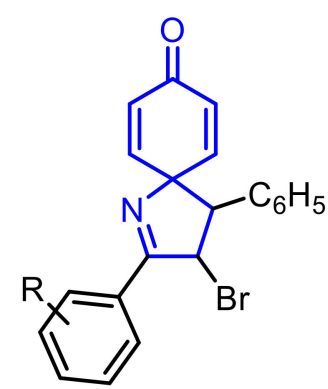

38a: $\mathrm{R}=\mathrm{H}, 83 \%$

38b: $\mathrm{R}=2-\mathrm{Cl}, 64 \%$

38c: $\mathrm{R}=4-\mathrm{Cl}, 80 \%$

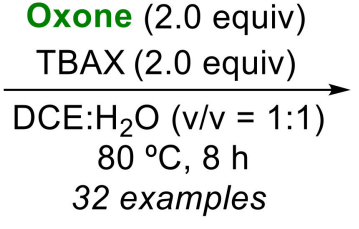

$53-85 \%$<smiles>[R]c1ccc(C2C(I)C(c3ccc(C)cc3)=NC23C=CC(=O)C=C3)cc1</smiles>

38h: $\mathrm{R}=\mathrm{H}, 80 \%$

38i: $\mathrm{R}=2-\mathrm{Cl}, 58 \%$

38k: $\mathrm{R}=\mathrm{H}, 82 \%$

38j: $\mathrm{R}=4-\mathrm{Cl}, 78 \%$

38I: $\mathrm{R}=4-\mathrm{OMe}, 76 \%$

$38 \mathrm{~m}: \mathrm{R}=4-\mathrm{Cl}, 75 \%$

Scheme 26. Oxone/TBAX-promoted spirocyclization of $p$-methoxyl alkynyl- $N$-phenylimines 37 .

In 2021, some of us reported the Oxone/RSeSeR-promoted electrophilic 6-endo-dig cyclization of alkynylbenzaldoximes 39, to access 3-organyl-4-(organylchalcogenyl)isoquinoline2-oxides 40 (Scheme 27) [31]. The process was conducted under ultrasound irradiation in the presence of $\mathrm{EtOH}$ as promoting reaction medium, affording twenty-one Se-containing $\mathrm{N}$-oxides $\mathbf{4 0}$ at good to excellent yields, within just a few minutes of reaction. Diaryl diselenides bearing electron-donating $\left(\mathrm{R}^{1}=4-\mathrm{MeOC}_{6} \mathrm{H}_{4}\right)$ and -withdrawing groups $\left(\mathrm{R}^{1}=4\right.$ $\mathrm{ClC}_{6} \mathrm{H}_{4}$ ) reacted smoothly to produce the products $40 \mathrm{~b}$ and $40 \mathrm{c}$ at excellent yields. Dialkyl $\left(\mathrm{R}^{1}={ }^{n} \mathrm{Bu}\right)$ and the sulfonamide-derivative diselenide $\left(\mathrm{R}^{1}=\mathrm{SO}_{2} \mathrm{NH}_{2} \mathrm{C}_{6} \mathrm{H}_{4}\right)$ were suitable substrates, affording the respective isoquinoline-2-oxides $40 \mathrm{~d}$ and $40 \mathrm{e}$ in $82 \%$ and $71 \%$ yield. In general, several electron-rich and electron-deficient alkynylbenzaldoximes 39 
were satisfactorily submitted to the optimal conditions. However, limitations were found when an alkyl group $\left(\mathrm{R}={ }^{t} \mathrm{Bu}\right)$ was attached in the $\mathrm{C} \equiv \mathrm{C}$ bond, and the conversion to the expected product $40 \mathrm{j}$ was not observed An interesting result was obtained when the alkynylbenzaldoxime $\mathbf{3 9 g}$, bearing the TMS group attached to the $\mathrm{C} \equiv \mathrm{C}$ bond $\left(\mathrm{R}=\mathrm{Si}(\mathrm{Me})_{3}\right)$ was employed as substrate. In this case, the expected product $40 \mathrm{k}$ was not afforded, and the reaction was driven to the $\mathrm{C} 3$-free product 401 , obtained in $88 \%$ yield. The same product 401 could be accessed from the unprotected terminal alkynylbenzaldoxime $39 \mathrm{~h}$ at an $85 \%$ yield (Scheme 27).<smiles>[R]C#Cc1ccccc1/C=N/O</smiles>

$\mathrm{R}, \mathrm{R}^{1}=$ alkyl, aryl

\section{Selected examples}<smiles>[R15]c1c(-c2ccccc2)[n+]([O-])cc2ccccc12</smiles>

40a: $\mathrm{R}^{1}=\mathrm{C}_{6} \mathrm{H}_{5}, 90 \%$

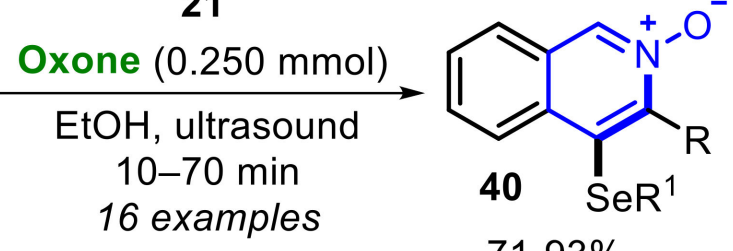
$71-93 \%$ 40b: $\mathrm{R}^{1}=4-\mathrm{MeOC}_{6} \mathrm{H}_{4}, 92 \%$

40c: $\mathrm{R}^{1}=4-\mathrm{ClC}_{6} \mathrm{H}_{4}, 93 \%$

40d: $\mathrm{R}^{1}={ }^{n} \mathrm{Bu}, 82 \%$

40e: $\mathrm{R}^{1}=\mathrm{SO}_{2} \mathrm{NH}_{2} \mathrm{C}_{6} \mathrm{H}_{4}, 71 \%$<smiles>[R]c1c([Se]c2ccccc2)c2ccccc2c[n+]1[O-]</smiles>

40f: $\mathrm{R}=4-\mathrm{MeC}_{6} \mathrm{H}_{4}, 91 \%$

40g: $\mathrm{R}=4-\mathrm{EtC}_{6} \mathrm{H}_{4}, 84 \%$

40h: $\mathrm{R}=4-\mathrm{ClC}_{6} \mathrm{H}_{4}, 87 \%$

40i: $\mathrm{R}={ }^{n} \mathrm{Bu}, 84 \%$<smiles>CC(C)(C)c1c([Se]c2ccccc2)c2ccccc2c[n+]1[O-]</smiles>

40j: ND<smiles>C[Si](C)(C)c1c([Se]c2ccccc2)c2ccccc2c[n+]1[O-]</smiles>

40k: ND<smiles>[O-][n+]1cc([Se]c2ccccc2)c2ccccc2c1</smiles>

from $39 g$ : $88 \%$ from $39 \mathrm{~h}: 85 \%$

Scheme 27. Oxone/RSeSeR-promoted electrophilic cyclization of alkynylbenzaldoximes 39.

The protocol was satisfactorily expanded to diaryl ditellurides $41 \mathbf{a}-\mathbf{c}$ and dibutyl ditelluride 41d, affording tellurium-functionalized isoquinoline-2-oxides 40p-s in good to very good yields (Scheme 28). No reaction was observed using diphenyl disulfide 42a, and 4-(phenylthio)isoquinoline-2-oxide 40t, was not obtained, even after $60 \mathrm{~min}$ under sonication. 
<smiles>[R]C#Cc1ccccc1/C=N/O</smiles><smiles>[R]OC(=O)O[R]</smiles><smiles>CCO[R6](=O)OC</smiles>
10-70 min 4 examples<smiles>[R]c1c([R]([R])([H])[O-])c2ccccc2c[n+]1[O-]</smiles><smiles>[O-][n+]1cc2ccccc2c([Te]c2ccccc2)c1-c1ccccc1</smiles>

40p: $80 \%$<smiles>[R]c1ccc([Te]c2c(-c3ccccc3)[n+]([O-])cc3ccccc23)cc1</smiles>

40q: $\mathrm{R}^{1}=4-\mathrm{Me}, 76 \%$

40r: $\mathrm{R}^{1}=4-\mathrm{Cl}, 70 \%$<smiles>CC(C)(C)c1c(-c2ccccc2)[n+]([O-])cc2ccccc12</smiles><smiles>O=[N+]([O-])c1ccccc1Sc1c(-c2ccccc2)[n+]([O-])cc2ccccc12</smiles>

Scheme 28. Oxone/RTeTeR-promoted electrophilic cyclization of alkynylbenzaldoximes 39.

\section{Oxygen-Containing Heterocycles}

Oxygen-containing heterocycles are an important class of compounds, which are abundantly found in nature, and are especially important in the industry, being widely used as flavor and fragrances [32]. Furthermore, these compounds present an important range of biological activities, including anticancer [33], immunosuppressive and hypolipidemic [34] As a consequence of the importance of these compounds, several innovative, simple and efficient Oxone-based protocols have been recently developed to synthesize oxygencontaining heterocycles.

In 2018, Qiu and co-workers reported the Oxone/TBAB-promoted 5-exo-dig oxycyclization of 2-alkynylbenzamide 43 to access isobenzofuran-1-imines 44 and isobenzofuran 45 selectively, in the presence of $\mathrm{K}_{2} \mathrm{CO}_{3}$ (Scheme 29A,B) [35]. Under the optimized reaction conditions, the product $\mathbf{4 4}$ is mostly formed at good to very good yields. However, the product 45 could be accessed at moderate to very good yields using an additional HCl-based hydrolysis step (Scheme 29).

In 2019, Liu and co-workers described the TBAB-catalyzed Oxone-mediated 6-endo-dig oxidative annulation of 2-alkynylbenzamide 43 to access several substituted isocoumarin1-imines 46 (Scheme 30) [36]. Differently substituted 2-alkynylbenzamides 43, bearing electron-rich and electron-deficient aryl and alkyl groups, were suitably employed as substrates, affording the respective products 46 regioselectively, in moderate do very good yields. Limitations were found when 2-ethynyl- $N$-phenylbenzamide 431 was employed as substrate, and the respective isocoumarin-1-imine 461 was not formed. 
A<smiles>[R]C#Cc1ccccc1C(=O)N[R]</smiles>

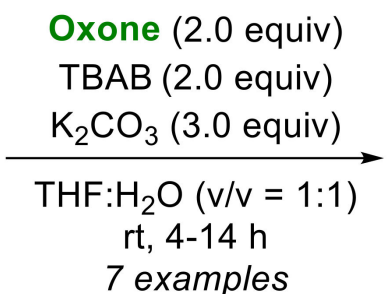

7 examples

$\mathrm{R}=\mathrm{H} ; \mathrm{R}^{1}=$ phenyl; $\mathrm{R}^{2}=$ aryl, alkyl

B<smiles>[R]C#CC1=C(C(=O)N[R])C=C[R1]C=C1</smiles>

43

1) Oxone (2.0 equiv)

TBAB (2.0 equiv)

$\frac{\mathrm{K}_{2} \mathrm{CO}_{3} \text { (3.0 equiv) }}{\text { THF: } \mathrm{H}_{2} \mathrm{O}(\mathrm{v} / \mathrm{v}=1: 1)}$

rt, 8-12 h

2) $0.5 \mathrm{~mL} \mathrm{HCl}$ (conc.)

$2 \mathrm{~h}$

17 examples<smiles>[R1]CC[R5]([R5])([H])Br</smiles>

$\mathrm{R}=3-\mathrm{Me}, 3-\mathrm{Br}, 3-\mathrm{Cl}, 3-\mathrm{F}, 5-\mathrm{Me}$;

$\mathrm{R}^{1}=$ aryl, alkyl, heteroaryl; $\mathrm{R}^{2}=\mathrm{Me}$

\section{Selected examples}<smiles>[R2]N=C1O/C(=C(\[CH2])Br)c2ccccc21</smiles>

44a: $R^{2}=\mathrm{C}_{6} \mathrm{H}_{5}, 78 \%$

44b: $R^{2}=B n, 82 \%$

44c: $R^{2}=M e, 85 \%$

44d: $R^{2}={ }^{t} \mathrm{Bu}, 77 \%$<smiles>[R]c1ccc2c(c1)C(=O)O/C2=C(/[15CH2])Br</smiles>

45a: $R=H, 81 \%$

45b: $R=M e, 88 \%$

45c: $\mathrm{R}=\mathrm{Br}, 65 \%$

45d: $R=F, 66 \%$<smiles>[R]c1ccc(/C(Br)=C2\OC(=O)c3ccccc32)cc1</smiles>

45e: $R=F, 70 \%$

45f: $\mathrm{R}=\mathrm{Cl}, 74 \%$

45g: $\mathrm{R}=\mathrm{OMe}, 63 \%$<smiles>O=C1O/C(=C(/Br)c2cccs2)c2ccccc21</smiles>

45h: $83 \%$<smiles>O=C1O/C(=C(/Br)C2=CCCCC2)c2ccccc21</smiles>

45i: $65 \%$<smiles>O=C1O/C(=C(\Br)CCO)c2ccccc21</smiles>

45j: $76 \%$<smiles>CS(=O)(=O)/C(Br)=C1\OC(=O)c2ccccc21</smiles>

45k: $86 \%$

Scheme 29. Oxone/TBAB-promoted 5-exo-dig oxy-cyclization of 2-alkynylbenzamide 43. (A) Synthesis of isobenzofuran-1-imines 44. (B) Synthesis of isobenzofuran 45.

During their studies, the authors noticed that when the $\mathrm{N}$-phenyl 2-trimethylsilylethynyl benzamides $\mathbf{4 7}$ was submitted to the optimal reaction conditions, isobenzofuran-1-imines 48 were obtained as the major product, through an oxidative 5-exo-dig annulation (Scheme 31). Inspired by this result, they decided to investigate the reaction scope, employing several meta-substituted $N$-phenyl 2-trimethylsilylethynylbenzamides 47 , bearing electrondonating and electron-withdrawing groups $(\mathrm{R}=\mathrm{H}, \mathrm{Me}, \mathrm{F}, \mathrm{Br}$ and $\mathrm{Cl})$, and the respective products 48 were obtained in very good yields. 
<smiles>[R]C#Cc1ccccc1C(=O)Nc1ccccc1</smiles>

$\operatorname{TBAB}(0.1$ equiv)

Oxone (2.0 equiv)

TFH: $\mathrm{H}_{2} \mathrm{O}(\mathrm{v} / \mathrm{v}=1: 1)$

$80^{\circ} \mathrm{C}$, overnight

17 examples

$\mathrm{R}=5-\mathrm{Me}, 5-\mathrm{OMe}, 3-\mathrm{Me}, 5-\mathrm{F}, 5-\mathrm{Cl}$

$\mathrm{R}^{1}=$ alkyl, aryl

Selected examples

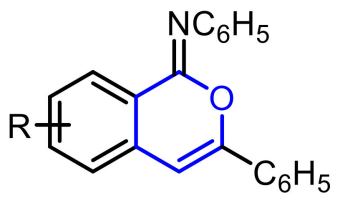

46a: $R=5-M e, 73 \%$

46b: $\mathrm{R}=5-\mathrm{OMe}, 67 \%$

46c: $R=3-M e, 53 \%$

46d: $R=5-F, 60 \%$

46e: $\mathrm{R}=5-\mathrm{Cl}, 62 \%$

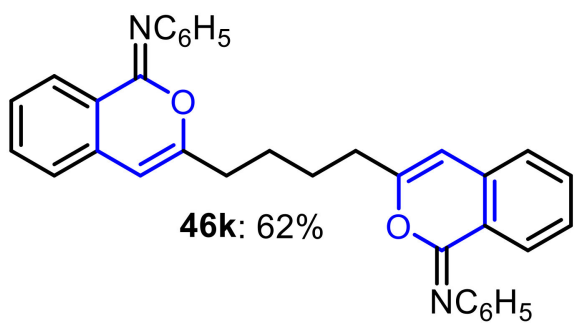

46h: $R^{1}={ }^{t} \mathrm{Bu}, 85 \%$<smiles></smiles>

46

$53-85 \%$

46f: $\mathrm{R}^{1}=4-\mathrm{MeC}_{6} \mathrm{H}_{4}, 74 \% \quad$ 46j: $60 \%$<smiles>CCCCCC(C)(C)Oc1cc2ccccc2c(=NOC(C)(C)C)o1</smiles>

46g: $R^{1}=4-\mathrm{MeOC}_{6} \mathrm{H}_{4}, 65 \%$

46i: $\mathrm{R}^{1}=$ phenylpropanyl, $64 \%$

Scheme 30. TBAB-catalyzed Oxone-mediated 6-endo-dig oxidative annulation of 2-alkynylbenzamide 43.<smiles>C#CC#Cc1ccccc1C(=O)NCCCCC</smiles>

TBAB (0.1 equiv)

Oxone (2.0 equiv)

$\mathrm{K}_{2} \mathrm{CO}_{3}$ (3.0 equiv)

$\mathrm{TFH}: \mathrm{H}_{2} \mathrm{O}(\mathrm{v} / \mathrm{v}=1: 1)$

$80^{\circ} \mathrm{C}$, overnight

5 examples<smiles>CCCCCN=c1occc2ccccc12</smiles>

46I: ND<smiles>C=C1OC(=N)c2ccccc21</smiles>

48a: $86 \%$<smiles>C=C1OC(=NCCCCCCCCC)c2cc(C)ccc21</smiles>

48b: $84 \%$<smiles>[R]c1ccc2c(c1)C(=C)OC2=[15NH]</smiles>

$81-86 \%$<smiles>C=C1OC(=N)c2cc(Br)ccc21</smiles>

48d: $83 \%$<smiles>C=C1OC(=NCCCC)c2cc(F)ccc21</smiles>

48c: $81 \%$<smiles>C=C1OC(=N)c2cc(Cl)ccc21</smiles>

48e: $82 \%$

Scheme 31. TBAB-catalyzed Oxone-mediated synthesis of isobenzofuran-1-imines 48.

In the same year, Wang, Sun, and co-workers reported the Pd(II)-catalyzed Oxonemediated oxidative sequential addition-annulation of 1,2-naphthofuroquinones 49 with diaryl alkynes 50, to prepare functionalized naphthofuroquinones 51 (Scheme 32) [37]. The 
method was efficiently applied to several functionalized 2-hydroxy-1,4-naphthoquinones 49, bearing electron-neutral, -donating, and -withdrawing aryl substituents. Regarding the diaryl alkyne counterpart 50, symmetrical and unsymmetrical, as well as electron-rich and electron-deficient derivatives could be converted to the respective naphthofuroquinone $\mathbf{5 1}$ in poor to very good yields. The biological potential of the synthesized products was evaluated, and the naphthofuroquinone 51a presented a potent endothelial protective activity.

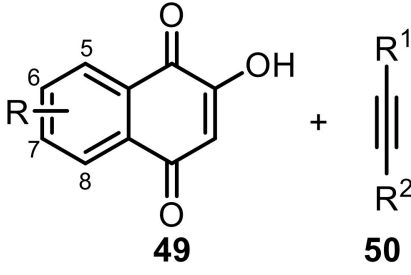

Selected examples

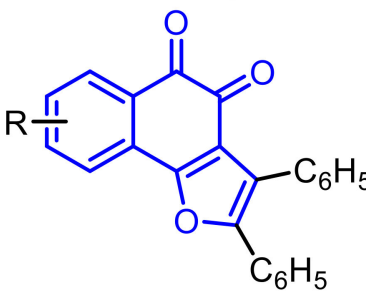

51a: $\mathrm{R}=\mathrm{H}, 77 \%$

51b: $R=6-\mathrm{OMe}, 81 \%$

51c: $R=6-F, 50 \%$

51d: $R=6-\mathrm{Cl}, 55 \%$

51e: $\mathrm{R}=7-\mathrm{Cl}, 48 \%$<smiles>[R]c1c(CCCCC)oc2c1C(=O)C(=O)c1ccccc1-2</smiles>

51f: $\mathrm{R}^{1}=\mathrm{CONMe}_{2}, 41 \%$

51g: $R^{1}=M e, 33 \%$<smiles>[R]c1oc2c(c1[R])C(=O)C(=O)c1ccccc1-2</smiles>

51h: $\mathrm{R}^{1}=\mathrm{R}^{2}=4-\mathrm{MeOC}_{6} \mathrm{H}_{4}, 77 \%$

51i: $R^{1}=R^{2}=4-F_{6} \mathrm{H}_{4}, 62 \%$

51j: $\mathrm{R}^{1}=\mathrm{R}^{2}=4-\mathrm{ClC}_{6} \mathrm{H}_{4}, 59 \%$

$51 k: R^{1}=R^{2}=2$-naphthyl, $68 \%$

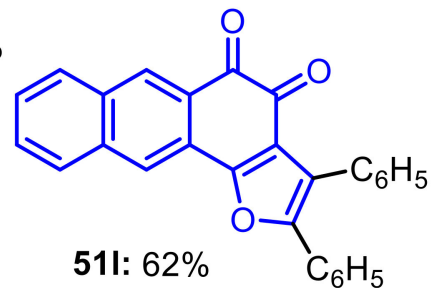

Scheme 32. $\mathrm{Pd}(\mathrm{II})$-catalyzed Oxone-mediated oxidative annulation of 1,2-naphthofuroquinone 49 and diaryl alkynes 50 .

Recently, Liu, Zhou, Qiu and co-workers described the Oxone/TBAB-promoted radical cyclization of 2-alkynylbenzoic acids 52, to construct isocoumarins 53, employing catalytic amounts of TBAB (10 mol\%) (Scheme 33) [38]. Substituted 2-alkynylbenzoic acids 52 bearing electron-donating and -withdrawing groups were satisfactorily employed, affording a total of eighteen functionalized isocoumarins $\mathbf{5 3}$ in moderate to very good yields. Regarding the alkynylbenzoic aryl moiety, when the system was deactivated $(\mathrm{R}=3-\mathrm{Cl}$ and 3-F), a slight loss in the reaction efficiency to access the products 53d and 53e was faced, whereas electron-donating groups ( $\mathrm{R}=4-\mathrm{Me}$ and $3-\mathrm{OMe})$ did not affect the reactivity remarkably. Interestingly, the method was extended to the bis-functionalized substrate $2,2^{\prime}-$ (octa-1,7-diyne-1,8-diyl)dibenzoic 52f, giving the corresponding isocoumarin $53 \mathrm{f}$ in $72 \%$ yield. Additionally, 2-alkynylbenzoic acids 52 bearing vinyl and alkyl groups attached in the $\mathrm{C} \equiv \mathrm{C}$ bond, reacted smoothly to produce the products $\mathbf{5 3} \mathbf{j}-\mathbf{k}$ at good yields (Scheme 33 ).

The first step of the reaction mechanism is the formation of the bromo radical (Br•) species, as proposed in Schemes 21 and 23. In the sequence, the 2-alkynylbenzoic acid $\mathbf{5 2}$ is oxidized, affording the oxygen-centered radical species $\mathbf{A}$, which quickly undergoes a 6 -endo-dig radical annulation to produce the isocoumarin radical B. Finally, after a radical hydrogen abstraction, the intermediate $\mathbf{B}$ is converted to the isocoumarin $\mathbf{5 3}$ (Scheme 34). 
<smiles>[R]C#CC1=C(C(=O)O)C=C[R]C=C1</smiles>

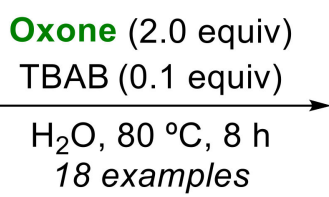

$\mathrm{R}=\mathrm{H}, 4-\mathrm{Me}$, 3-Me, 3-OMe, 3-Cl, 3-Br, 3-F $\mathrm{R}^{1}=$ aryl, alkyl

\section{Selected examples}

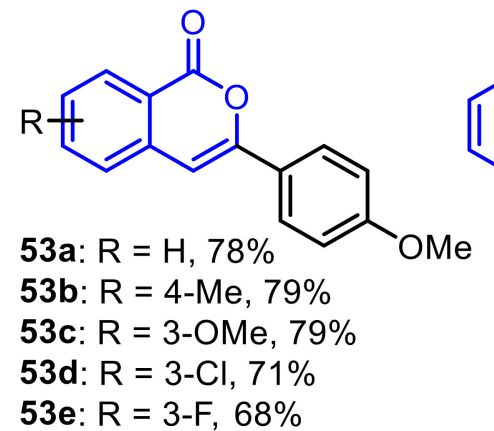<smiles>COc1ccc2cc(-c3ccc(OC)c(OC)c3)oc(=O)c2c1</smiles><smiles></smiles>

53h: $\mathrm{R}^{1}=2-\mathrm{MeOC}_{6} \mathrm{H}_{4}, 67 \%$

53i: $\mathrm{R}^{1}=2-\mathrm{ClC}_{6} \mathrm{H}_{4}, 63 \%$

53j: $\mathrm{R}^{1}=$ nonyl, $76 \%$

53k: $\mathrm{R}^{1}=$ cyclohexenyl, $60 \%$

Scheme 33. Oxone/TBAB-promoted radical cyclization of 2-alkynylbenzoic acids $\mathbf{5 2 .}$

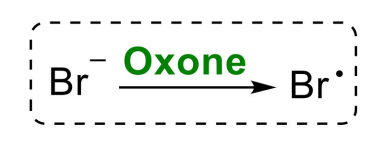<smiles>[R]C#CC1=CC=[R]#CC=C1C(=O)O</smiles><smiles>CC(Br)C(Br)Br</smiles><smiles>[R]C#Cc1cc#ccc1C(=O)[O-]</smiles><smiles>[R1]C=Cc1cccc2c(=O)oc([R])cc12</smiles>

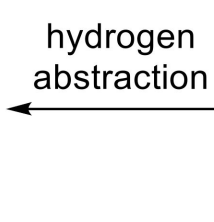<smiles></smiles>

Scheme 34. Reaction mechanism of the Oxone/TBAB-promoted radical cyclization of 2-alkynylbenzoic acids 52 .

The system TBAB/Oxone was also employed in the 5-exo-dig bromocyclization of 2-alkynylbenzoic acids 52, aiming the synthesis of 3-(bromomethylene)isobenzofuran1(3H)-ones 54, employing overstoichiometric amounts of TBAB (1.5 equiv) (Scheme 35) [39]. A total of fifteen 3-(bromomethylene)isobenzofuran-1(3H)-ones 54 were obtained in mod- 
erate to very good yields, starting from alkynyl-substituted substrate $\mathbf{5 2}$ bearing electronrich and -deficient aryl groups. Good results were obtained using the vinyl derivative 52h $\left(\mathrm{R}^{1}=\right.$ cyclohex-1-enyl), which reacted smoothly to yield the product $54 \mathrm{~h}$ at a $67 \%$ yield. Equally good outcomes were observed using Csp-substituted with alkyl groups $\left(\mathrm{R}^{1}=\right.$ phenylpropanyl, ${ }^{n} \mathrm{Bu}$ and $\left.{ }^{t} \mathrm{Bu}\right)$, and the respective products $54 \mathbf{i}-\mathbf{k}$ were obtained at good yields (Scheme 35).<smiles>[R]C#CC1=C(C(=O)O)C=C[R]C=C1</smiles>

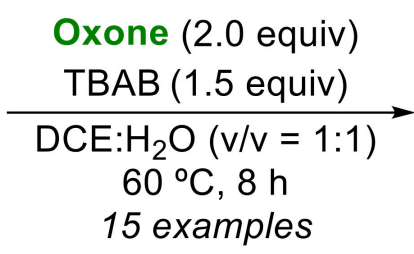<smiles>[R]C(Br)=C1OC(=O)c2ccccc21</smiles>

$\mathrm{R}=\mathrm{H}, 4-\mathrm{Me}$, 3-Me, 3-Cl, 3-Br, 3-F; $\mathrm{R}^{1}$ = aryl, alkyl

\section{Selected examples}<smiles>[R][X]c1ccc(C(Br)=C2OC(=O)c3ccccc32)cc1</smiles>

54a: $\mathrm{R}=\mathrm{H}, 75 \%$

54b: $\mathrm{R}=4-\mathrm{Cl}, 53 \%$

54c: $R=4-O M e, 79 \%$<smiles>O=C1O/C(=C(/Br)C2=CCCCC2)c2ccccc21</smiles>

54h: $67 \%$<smiles>[R]c1ccc(/C(Br)=C2\OC(=O)c3ccccc32)cc1</smiles>

54d: $R=3-\mathrm{Me}, 82 \%$

54e: $R=4-M e, 78 \%$

54f: $\mathrm{R}=3-\mathrm{Cl}, 72 \%$

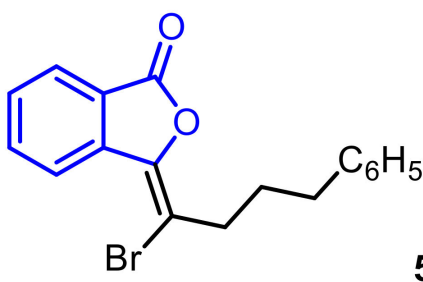

54i: $68 \%$<smiles>CC(C)(C)/C(Br)=C1\OC(=O)c2cc(F)ccc21</smiles>

54g: $70 \%$<smiles>[R]/C(Br)=C1\OC(=O)c2ccccc21</smiles>

54j: $\mathrm{R}^{1}={ }^{n} \mathrm{Bu}, 79 \%$

54k: $\mathrm{R}^{1}={ }^{t} \mathrm{Bu}, 76 \%$

Scheme 35. Oxone/TBAB-promoted radical cyclization of 2-alkynylbenzoic acids 52.

The proposed mechanism of the formation of $\mathbf{5 4}$ from $\mathbf{5 2}$ has two possible pathways (Scheme 36). Initially, an Oxone-promoted SET process affords the bromo radical intermediate, which discloses the radical process. Thus, considering the pathway 1 , the substrate 52 is initially oxidized by the bromo radical $(\mathrm{Br} \bullet)$, releasing $\mathrm{HBr}$ and generating the 2alkynylbenzoic acid radical A. Once formed, $\mathrm{A}$ is reduced by another equivalent of $\mathrm{Br} \bullet$, to produce the alkynylbenzoic acid anion $\mathbf{B}$ and a bromonium ion $\left(\mathrm{Br}^{+}\right)$. Following on from this, the intermediate $\mathbf{B}$ undergoes a 5-exo-dig cyclization to form the isobenzofuran-1-one anion $\mathbf{C}$, which combines with the bromonium ion, to afford the respective product 54 . On the other hand, in the pathway 2 , the bromo radical (Br•) firstly adds to the $\mathrm{C} \equiv \mathrm{C}$ bond, giving the intermediate $\mathbf{D}$, which is oxidized by Oxone, to afford the vinyl cation intermediate $\mathbf{E}$. Subsequently, an annulative process drives the reaction toward the intermediate $\mathbf{F}$, which is finally converted to the desired product 54 by deprotonation (Scheme 36). 


\section{Pathway 1}

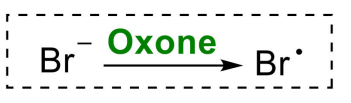<smiles>[R]C#Cc1ccccc1C(=O)O</smiles><smiles>[R]C#Cc1ccccc1C(=O)[O-]</smiles><smiles>[R][R]C1=C(Br)/C(=C(\[R])Br)OC1=O</smiles><smiles>[R]C=c1oc(=O)c2cc[R]:[R]cc1=2</smiles>

\section{Pathway 2}<smiles>[R]C#Cc1ccccc1C(=O)O</smiles><smiles>[R][R]O[C@@H](C)C(=O)O</smiles><smiles>[R1]C(Br)[C+]=C(C#[R])CC</smiles><smiles>[R][R]C=c1/c(=C(\[R1])Br)oc(=O)c2ccccc12</smiles><smiles>C[C+]C</smiles><smiles>[R][R]=C(Br)C1=[O+]C(O)c2cc[R](F)cc21</smiles>

Scheme 36. Plausible mechanism of the Oxone/TBAB-promoted radical cyclization of 2-alkynylbenzoic acids 52.

Very recently, some of us [40] described a simple and general Oxone/diselenidepromoted ultrasound-assisted protocol to prepare 4-chalcogenyl- $1 H$-isochromen-1-ones 55, through a 6-endo-dig electrophilic cyclization of 2-alkynylaryl esters 56 (Scheme 37) [40]. By using $\mathrm{EtOH}$ as solvent, the reaction scope to access Se-containing isochromen-1-ones $\mathbf{5 5}$ was investigated using several diorganyl dichalcogenides 21, 41, 42 and 2-alkynylaryl esters 56. Diaryl and dialkyl diselenides 21 were suitable substrates, yielding the products 55a-f in excellent yields, with the reaction time ranging between 30 and $50 \mathrm{~min}$. 2-Alkynylaryl esters 56 bearing a diversity of alkynyl-substituted groups (R groups) reacted smoothly to produce the products $55 \mathrm{~g}-\mathrm{j}$ in very good to excellent yields, in a reaction time ranging from 30 to $60 \mathrm{~min}$. For instance, some examples can be highlighted, including (1) the synthesis of C3-free isochromen-1-ones $55 \mathrm{~g}$, which may be derivatized through a TM-catalyzed cross-coupling strategy, as well as (2) the synthesis of the C3-alkyl derivative $55 \mathbf{j}$, both in high yields (Scheme 37). 


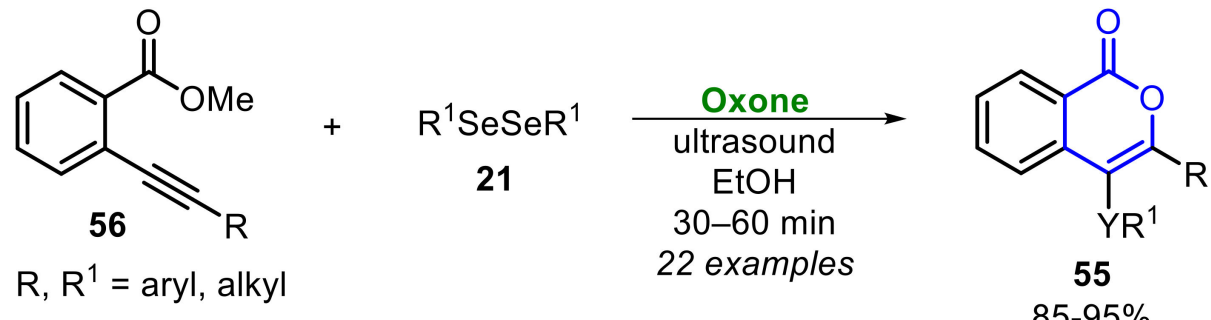

Selected examples

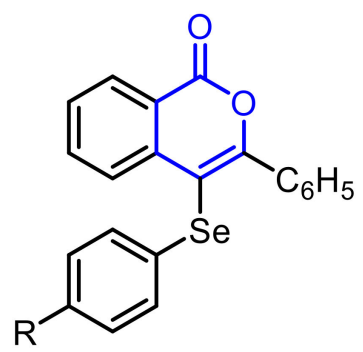

55a: $R=H, 95 \%, 30$ min 55b: $R=$ OMe, 93\%, 30 min 55c: $\mathrm{R}=\mathrm{Cl}, 90 \%, 50 \mathrm{~min}$

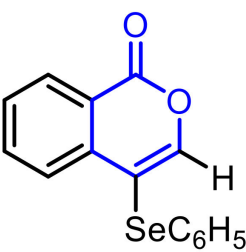<smiles>[R]c1oc(=O)c2ccccc2c1[SeH]</smiles>

55h: $\mathrm{R}=4-\mathrm{MeOC}_{6} \mathrm{H}_{4}, 90 \%, 30 \mathrm{~min}$ 55i: $\mathrm{R}=4-\mathrm{ClC}_{6} \mathrm{H}_{4}, 92 \%, 60 \mathrm{~min}$

55g: $89 \%, 30 \mathrm{~min}$<smiles>[R17]c1c([SeH])oc(=O)c2ccccc12</smiles>

55e: $\mathrm{R}^{1}=\mathrm{Et}, 90 \%, 40 \mathrm{~min}$

55f: $\mathrm{R}^{1}={ }^{n} \mathrm{Bu}, 94 \%, 35 \mathrm{~min}$

55d: $91 \%, 50 \min$<smiles>CCCCc1oc(=O)c2ccccc2c1[SeH]C(C)CC</smiles>

55j: $85 \%, 45 \mathrm{~min}$

Scheme 37. Oxone/diselenide-promoted electrophilic cyclization of 2-alkynylaryl esters 56.

The reaction scope was expanded to tellurium-containing isochromen-1-ones $55 \mathbf{k}-\mathbf{n}$, employing glycerol as solvent. Neutral and electron-rich aryl ditellurides $\mathbf{4 1}$ reacted smoothly to produce the respective products $55 \mathbf{k}-\mathbf{m}$ in very good yields, under sonication for $1 \mathrm{~h}$. Surprisingly, 4-chlorophenyl ditelluride and dibutyl ditelluride were not able to afford the respective tellurium-containing isochromen-1-ones 55; the formation of the 3-phenyl-1H-isochromen-1-one 55 n was observed in these cases. Moreover, a limitation was also found when diphenyl disulfide $\mathbf{4 2}$ was employed as substrate, and the expected sulfur-containing derivative 55o could not be obtained (Scheme 38).

In 2019, Ishihara and co-workers [41] described the Oxone-promoted dearomatization of functionalized arenols in the presence of quaternary ammonium hypoiodite. In this study, the authors proposed the use of two chiral quaternary ammonium hypoiodites (Figure 1), and carried out the oxidation of phenols, 1- and 2-naphthols.

Initially, several phenols substituted with aliphatic groups were used for the enantioselective oxidative spirolactonization using chiral ammonium hypoiodite $\mathbf{A}$ or $\mathbf{B}$ (Scheme 39). When using the phenols $57 \mathbf{a}-\mathbf{f}$, the corresponding spirolactones $58 \mathbf{a}-\mathbf{f}$ were obtained at moderate to good yields (73-95\%) and with good to high enantioselectivity (73-93\% ee) after $16-48 \mathrm{~h}$. It was observed that when naphthols with bulky substituents in the orthoposition were used, a decrease in the enantioselectivity of the respective compounds 58a, $\mathbf{5 8 b}$ and 58e was observed (Scheme 39). 


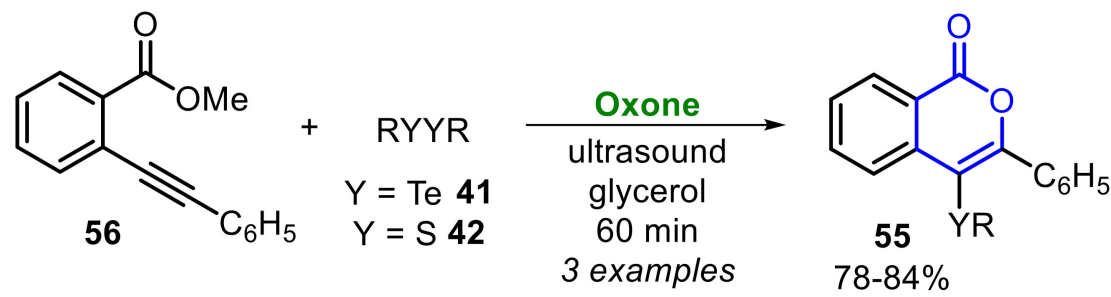

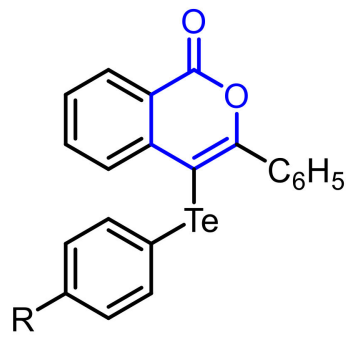

55k: $\mathrm{R}=\mathrm{H}, 84 \%$

55I: $\mathrm{R}=\mathrm{Me}, 82 \%$

55m: $\mathrm{R}=\mathrm{OMe}, 78 \%$

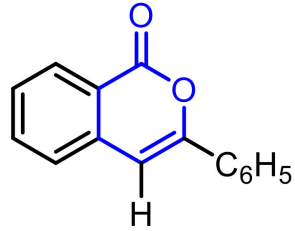

$55 n$

from $\left(4-\mathrm{ClC}_{6} \mathrm{H}_{4} \mathrm{Te}\right)_{2}: 84 \%$ from $\left({ }^{n} \mathrm{BuTe}\right)_{2}: 90 \%$

Scheme 38. Oxone/ditelluride-promoted electrophilic cyclization of 2-alkynylaryl esters 56.<smiles>Cc1c(Br)cc2ccccc2c1-c1c(C[N+](C)(C)Cc2ccc3ccccc3c2-c2c(Br)ccc3ccccc23)c(Br)cc2ccccc12</smiles>

A or $\mathbf{B}$<smiles>[R]c1cc([R])cc(-c2cc([R])cc(-c3cc([R])cc([14CH3])c3)c2)c1</smiles>

$\mathrm{R}=\mathrm{CF}_{3}(\mathbf{A}), \mathrm{CF}\left(\mathrm{CF}_{3}\right)_{2}$

Figure 1. Structures of quaternary ammonium hypoiodite $\mathbf{A}$ and $\mathbf{B}$.<smiles></smiles>

58a: 92\%, 63\% ee

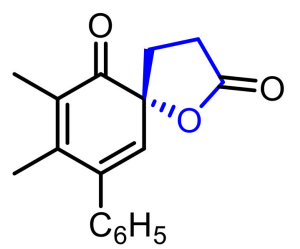

58d: $82 \%, 86 \%$ ee

$$
\begin{gathered}
\text { A }(10 \mathrm{~mol} \%) \\
\text { Oxone }(0.6 \text { equiv }) \\
\hline \text { toluene } / \mathrm{H}_{2} \mathrm{O}(\mathrm{v} / \mathrm{v}=20: 1) \\
0^{\circ} \mathrm{C}, 16-48 \mathrm{~h} \\
6 \text { examples }
\end{gathered}
$$<smiles>CCC1=C[C@]2(CCC(=O)O2)C(=O)C(C(C)(C)C)=C1</smiles>

58b: $83 \%, 73 \%$ ee<smiles>CC1=CC(C(C)C)=CC2(CCC(=O)O2)C1=O</smiles>

58e: $84 \%, 74 \%$ ee

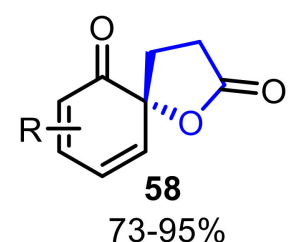<smiles>CCC1=CC(C(C)(C)C)=C[C@]2(CCC(=O)O2)C1=O</smiles>

58c: $73 \%, 93 \%$ ee

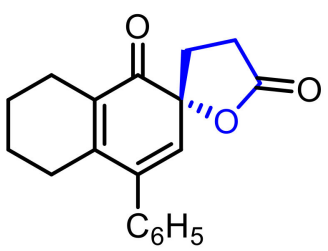

58f: $95 \%, 93 \%$ ee

Scheme 39. Enantioselective oxidation of phenols 57a-f. 
Concomitantly, under the optimized conditions, several 2-naphthol 59a-c derivatives were oxidized to the corresponding spirolactones $58 \mathrm{~g}-\mathbf{i}$ in very good to excellent yields $(88-96 \%)$, and with high enantioselectivity $(85-91 \% e e)$, regardless of the electronic nature and position of the substituents (Scheme 40). The best hypoiodite in this reaction was the derivative $\mathbf{B}$.

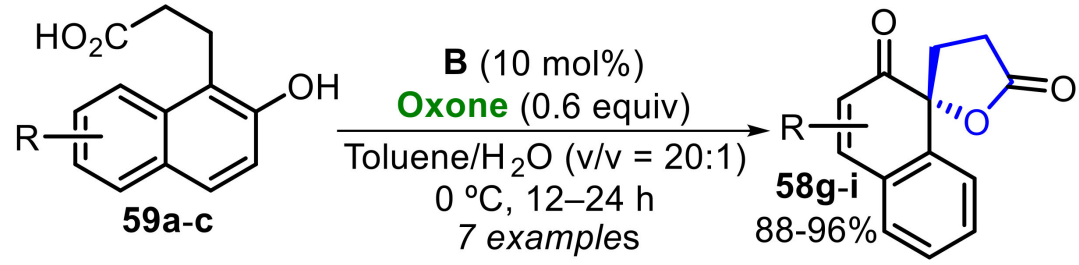

$\mathrm{R}=\mathrm{H}, 3-\mathrm{Br}, 6-\mathrm{Br}$, 8-F, 4-Me, 7-OBn, 7-OMe

Selected examples<smiles>O=C1CC[C@]2(O1)C(=O)C=Cc1cc(Br)ccc12</smiles><smiles>O=C1CC[C@]2(O1)C(=O)C(Br)=Cc1ccccc12</smiles>

58h: $96 \%, 91 \%$ ee<smiles>CC1=CC(=O)[C@]2(CCC(=O)O2)c2ccccc21</smiles>

58i: $92 \%, 88 \%$ ee

58g: $88 \%, 90 \%$ ee

Scheme 40. Enantioselective oxidation of 2-naphthols 59a-c.

On the other hand, the oxidation of 1-naphthols $59 \mathbf{d}-\mathbf{f}$ was examined using hypoiodite A/Oxone catalysis under two conditions: the optimal one described above $(\operatorname{method} \mathrm{A})$, and for comparison the reactions were carried out using 2 equiv. of $\mathrm{H}_{2} \mathrm{O}_{2}$ (method $\mathrm{B}$ ), this condition was tested in the reaction optimization step. Thus, the corresponding spirolactones $\mathbf{5 8} \mathbf{j}-\mathbf{1}$ were obtained at higher chemical yields and enantioselectivity, and in shorter reaction times when using method $\mathrm{A}$. These results again demonstrated the good efficiency of hypoiodite/Oxone catalysis (Scheme 41).

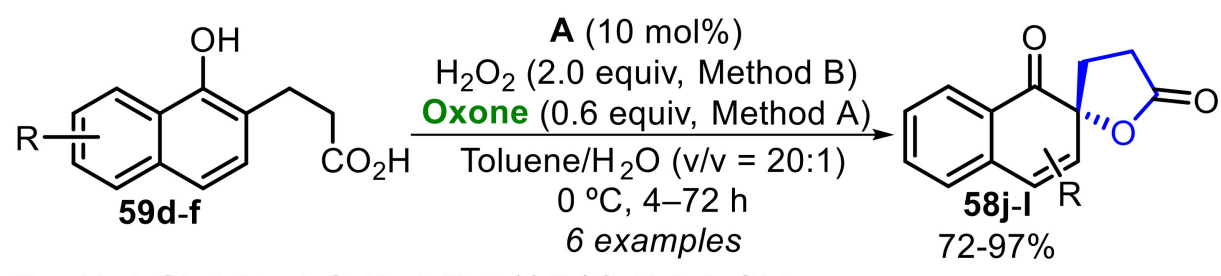

$\mathrm{R}=\mathrm{H}, 4-\mathrm{Cl}, 4-\mathrm{Br}, 4-\mathrm{C}_{6} \mathrm{H}_{5}, 4-\left[3,5-\left(\mathrm{CF}_{3}\right) \mathrm{C}_{6} \mathrm{H}_{3}\right], 3-\mathrm{OMe}$

Selected examples<smiles>O=C1CC[C@]2(C=C(Cl)c3ccccc3C2=O)O1</smiles>

58j:

A: $97 \%, 91 \%$ ee

B: $84 \%, 88 \%$ ee

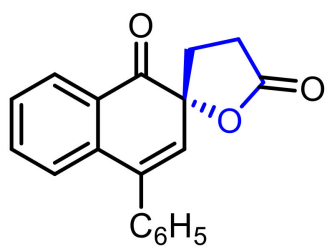

58k:

A: $83 \%, 88 \%$ ee<smiles>O=C1CC[C@]2(C=C(Br)c3ccccc3C2=O)O1</smiles>

58I:

A: $94 \%, 94 \%$ ee

B: $72 \%, 88 \%$ ee

Scheme 41. Enantioselective Oxidation of 1-Naphthols 59d-f. 


\section{Organochalcogen-Containing Heterocycles}

Chalcogenophenes are a valuable class of heterocyclic compounds, which play an important role as building blocks in organic synthesis [42], in the development of new materials $[43,44]$, and in the prospection of new drugs in the pharmaceutical industry [45,46]. Due to these important features, the search for the development of simple and efficient methods to access chalcogenophenes has attracted interest during the last decades. In this context, the use of the system Oxone/dichalcogenide has demonstrated to be a very efficient strategy to access chalcogenophenes through chalcogen-based electrophilic cyclization processes.

In 2020, some of us reported an Oxone/dichalcogenide-promoted synthesis of 3selanyl-chalcogenophenes and 3-tellanylchalcogenophenes 60-62, through the electrophilic cyclization of (Z)-chalcogenoenynes 63-65, under ultrasound irradiation (Scheme 42) [47]. The annulation of (Z)-1-butylselen-1-en-3-ynes 63 was conducted in the presence of several diorganyl diselenides 21 and diphenyl ditelluride 41a, affording the respective 3arylselanyl- and 3-aryltellanylselenophenes $\mathbf{6 0}$ in poor to very good yields. Initially, by employing diphenyl diselenide 21a, the respective product 60 a was obtained in $87 \%$ yield. On the other hand, the reaction was remarkably affected by the presence of substituents attached to the Se-phenyl ring, and the products $60 \mathrm{~b}$-d were obtained in just $40-54 \%$ yield. Heteroaryl diselenides 21 ( $R=2$-naphtyl and 2-thienyl) were smoothly submitted to the optimized reaction conditions to afford the corresponding products $\mathbf{6 0 e}$ and $\mathbf{6 0 f}$ in $59 \%$ and $42 \%$ yield, respectively. It is worth to mention that dibutyl diselenide 21 reacted efficiently to produce the selenophene $60 \mathrm{~g}$ in $60 \%$ yield. Finally, as already observed in other Oxone-promoted oxidative cleavage of the chalcogen-chalcogen bond, diphenyl disulfide 42a failed to access the expected product $60 \mathrm{~h}$, whereas diphenyl ditelluride 41a reacted satisfactorily to be converted to the tellurium-functionalized selenophene $60 \mathrm{i}$ at a $50 \%$ yield (Scheme 42 ).

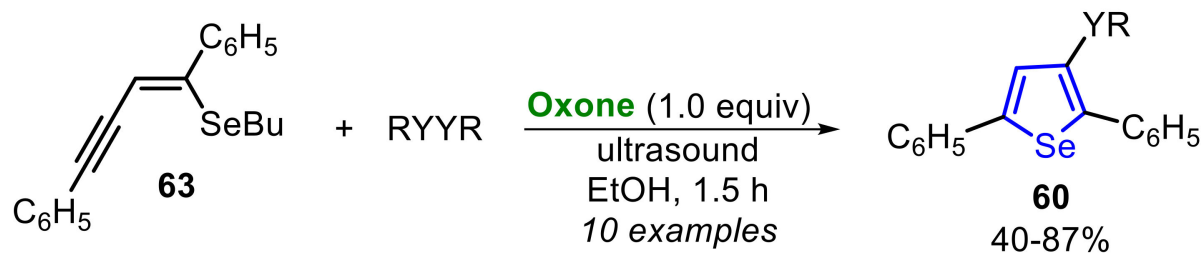

$\mathrm{Y}=\mathrm{S}$ 42, Se 21, Te 43; $\mathrm{R}=$ aryl, alkyl, heteroaryl

Selected examples

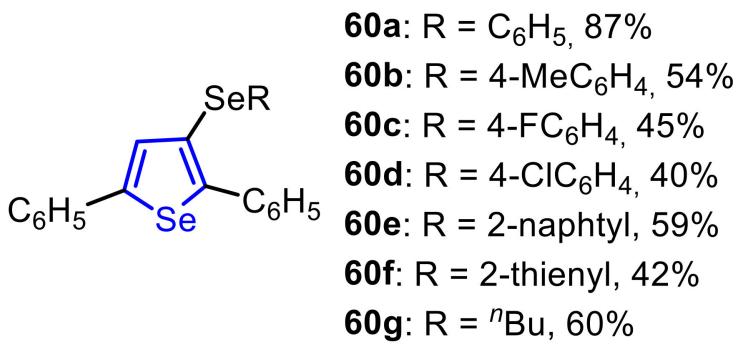<smiles>[Y]c1cc([AsH2-])[se]c1[13CH3]</smiles>

60h: $\mathrm{Y}=\mathrm{S} ; \mathrm{R}=\mathrm{C}_{6} \mathrm{H}_{5}, \mathrm{NR}$

60i: $Y=\mathrm{Te} ; \mathrm{R}=\mathrm{C}_{6} \mathrm{H}_{5}, 50 \%$

Scheme 42. Oxone/dichalcogenide-promoted annulation of (Z)-1-butylselen-1-en-3-ynes 63.

The reaction scope was expanded to (Z)-(1,4-diphenylbut-1-en-3-yn-1-yl)(propyl)sulfane 64a at the same optimal conditions, aiming to access a library of chalcogen-functionalized thiophenes $\mathbf{6 1}$ (Scheme 43). The authors observed that neutral and electron-rich diaryl diselenides 21 were suitable electrophile precursors, affording the respective 3-selanylthiophenes $61 \mathrm{a}-\mathrm{c}$ in $72 \%$ to $85 \%$ yield. However, the presence of halogen at the para-position of the Se-phenyl ring of the diaryl diselenide $\left(\mathrm{R}=4-\mathrm{FC}_{6} \mathrm{H}_{4}\right.$ and $\left.4-\mathrm{ClC}_{6} \mathrm{H}_{4}\right)$, prevented the formation of the respective thiophenes $61 \mathrm{~d}$ and $61 \mathrm{e}$. Dibutyl diselenide $21 \mathrm{f}$ reacted smoothly to produce 3-(butylselanyl)-2,5-diphenylthiophene 61f at a 69\% yield. Additionally, in this case, diphenyl disulfide 42a did not react with enyne 64 a to produce 3-sulfanylthiophene 
61g, whereas diphenyl ditelluride 41a was efficient in the synthesis of 3-(phenyltellanyl)2,5-diphenylthiophene $\mathbf{6 1 h}$, obtained at a $57 \%$ yield (Scheme 43 ).

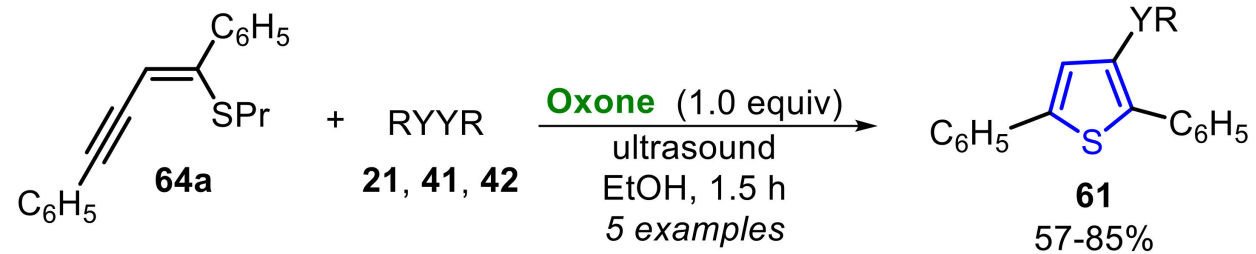

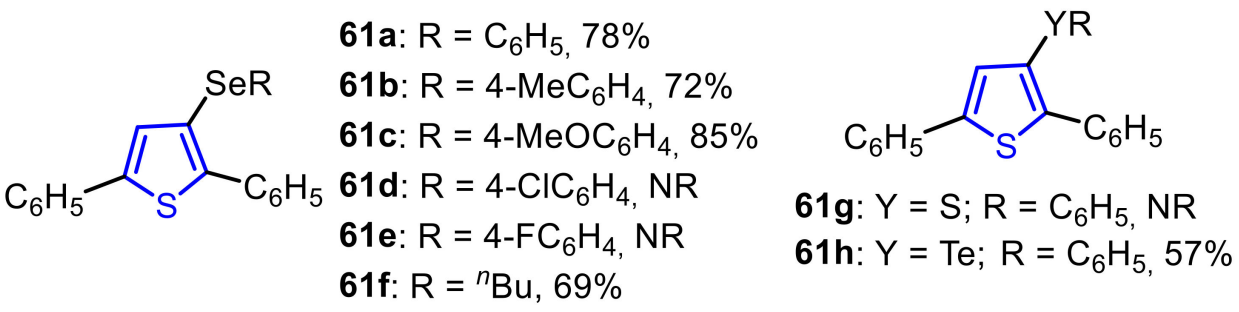

Scheme 43. Oxone/dichalcogenide-promoted annulation of (Z)-(1,4-diphenylbut-1-en-3-yn-1yl)(propyl)sulfane 64a.

Additionally, the protocol was expanded for the synthesis of tellurophenes 62, using $(Z)$ butyl(1,4-diphenylbut-1-en-3-yn-1-yl)tellane 65a in the reaction with Oxone/dichalcogenide, in the presence of glycerol as solvent. In this case, the reaction temperature could be increased to up $100{ }^{\circ} \mathrm{C}$ under ultrasound, which was necessary to allow the cyclization (Scheme 44). Under this condition, electron-rich and electron-deficient diaryl diselenides 21 reacted adequately to produce the products $\mathbf{6 2 a - c}$ at moderate yields, whereas dibutyl diselenide

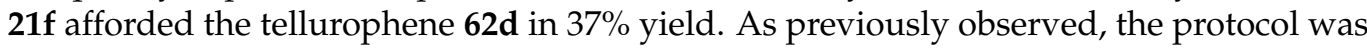
not suitable to diphenyl disulfide 42a, whereas 3-(phenyltellanyl)-2,5-diphenyltellurophene $62 \mathrm{f}$ was obtained in only $28 \%$ by the reaction between $65 \mathrm{a}$ and diphenyl ditelluride $41 \mathrm{a}$ under the optimal conditions (Scheme 44).

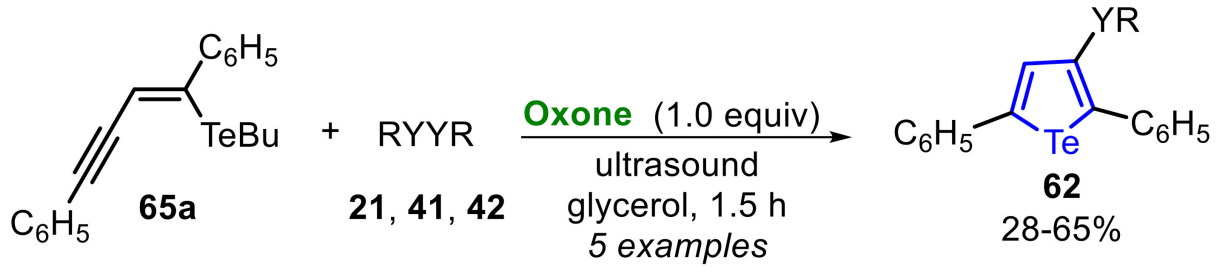<smiles></smiles>

$$
\begin{aligned}
& \text { 62a: } \mathrm{R}=\mathrm{C}_{6} \mathrm{H}_{5}, 61 \% \\
& \text { 62b: } \mathrm{R}=4-\mathrm{MeC}_{6} \mathrm{H}_{4}, 41 \% \\
& \text { 62c: } \mathrm{R}=4-\mathrm{FC}_{6} \mathrm{H}_{4}, 65 \% \\
& \text { 62d: } \mathrm{R}={ }^{n} \mathrm{Bu}, 37 \%
\end{aligned}
$$

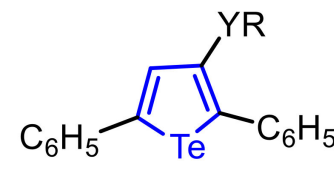

62e: $Y=S ; R=\mathrm{C}_{6} \mathrm{H}_{5}, \mathrm{NR}$

62f: $Y=T e ; R=\mathrm{C}_{6} \mathrm{H}_{5}, 28 \%$

Scheme 44. Oxone/dichalcogenide-promoted annulation of (Z)-butyl(1,4-diphenylbut-1-en-3-yn-1yl)tellane $65 a$.

The proposed reaction mechanism for the electrophilic cyclizations follows an ionic and a radical step simultaneously (Scheme 45). Initially, the reactive intermediates A and $\mathbf{B}$ are obtained via anionic or radical pathways, by the reaction between the diorganyl dichalcogenide $\mathbf{2 1}$ or $\mathbf{4 1}$ and potassium peroxymonosulfate $\left(\mathrm{KHSO}_{5}\right.$, the active component of Oxone). Once formed, the intermediate $\mathbf{B}$ can be protonated to afford the strongest electrophile $B^{\prime}$. In the presence of chalcogenoenynes $\mathbf{6 3 , 6 4}$ or $\mathbf{6 5}$, the intermediates $A$ and $\mathbf{B}^{\prime}$ are converted to the chalcogenironium intermediate $\mathbf{C}$, that undergoes an intramolecular annulation to form the intermediate $\mathbf{D}$. Finally, an alkyl group displacement, promoted 
by a nucleophilic species from the reaction medium, yields the desired chalcogenophenes 60-63 (Scheme 45).

\section{formation of the chalcogen-based electrophilic species}

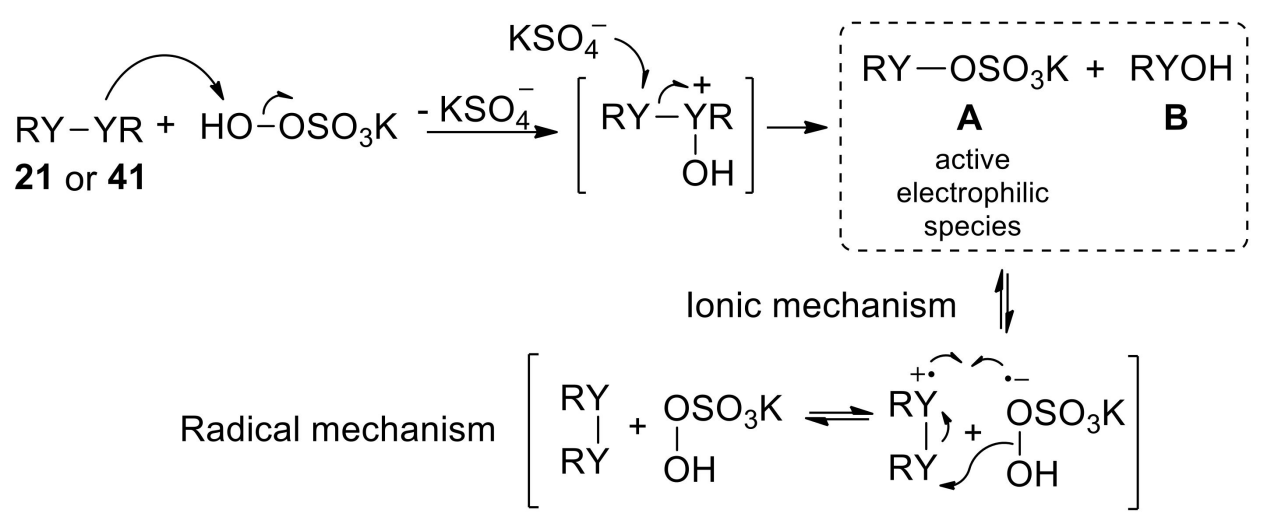

activation of intermediate $B$

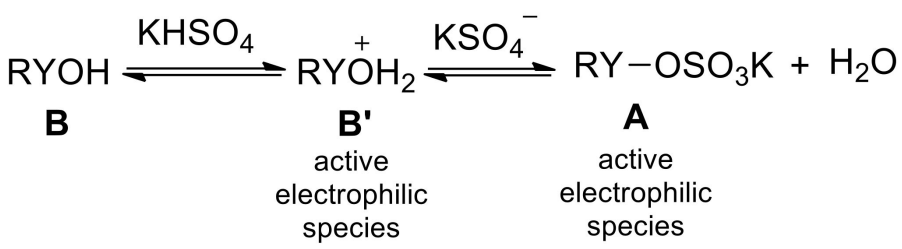

cyclization step
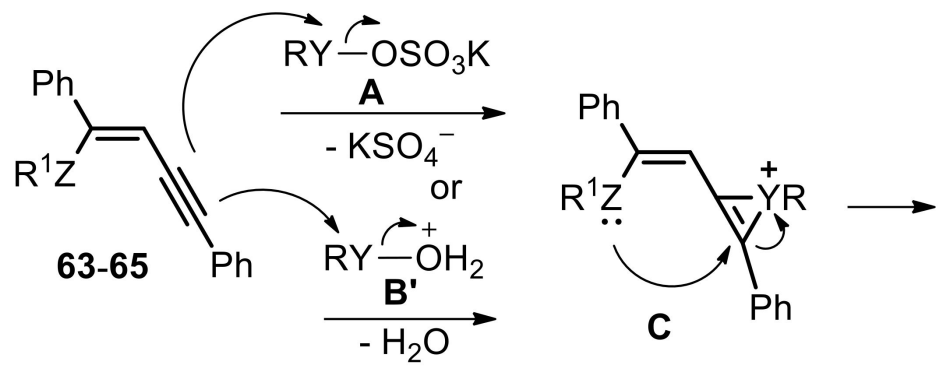

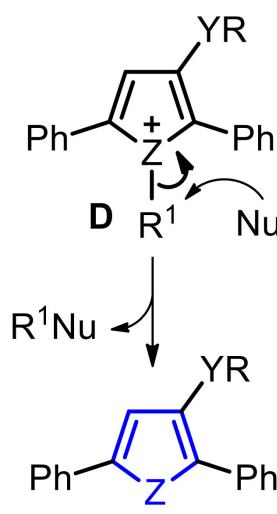

60-62

Scheme 45. Reaction mechanism for the Oxone/dichalcogenide-promoted cyclization of chalcogenoenynes.

In 2021, some of us reported an Oxone/dibutyl diselenide-promoted 5-endo-dig electrophilic cyclization of 1,3-diynes 66, to access selectively 3,4-bis(butylselanyl)selenophenes 67 and 4-alkoxyselenophenes 68 (Scheme 46) [48]. The selectivity in the formation of the products 67 and 68 was achieved by controlling the solvent $(\mathrm{MeCN}$ or $\mathrm{ROH})$ and the dibutyl diselenide $21 f$ amount (2 equiv or 1.5 equiv). Thus, by employing 2 equiv of dibutyl diselenide 21f in the presence of $\mathrm{MeCN}$ as solvent, 3,4-bis(butylselanyl)selenophenes 67 were prepared in moderate to good yields, after being stirred at $80^{\circ} \mathrm{C}$. Neutral and electronrich 1,3-diynes $66(\mathrm{R}=\mathrm{H}, \mathrm{OMe}$ and $\mathrm{Me})$ reacted adequately to yield the products $64 \mathbf{a}, 67 \mathbf{b}$ and $67 \mathrm{c}$ in $78 \%, 50 \%$ and $70 \%$ yield, respectively. On the other hand, the electron-deficient 1,4-bis(4-chlorophenyl)buta-1,3-diyne $\left(66 \mathrm{~d}, \mathrm{R}=4-\mathrm{ClC}_{6} \mathrm{H}_{4}\right)$ could not be converted to the expected product $\mathbf{6 7 d}$, even after $72 \mathrm{~h}$ of reaction. By employing dodeca-5,7-diyne (66e, 
$\mathrm{R}={ }^{n} \mathrm{Bu}$ ) as substrate, a complex mixture of products was obtained. Interestingly, 1,4di(naphthalen-2-yl)buta-1,3-diyne $\mathbf{6 6 f}$ allowed the formation of the selenophene $\mathbf{6 7 f}$ in $40 \%$ yield, after $48 \mathrm{~h}$. Finally, dibutyl ditelluride $\mathbf{4 1 d}$ and dimethyl disulfide $\mathbf{4 2 b}$ were submitted to the optimized reaction conditions; however, both were not able to produce the expected products $\mathbf{6 7 g}$ and $\mathbf{6 7 h}$, even after $72 \mathrm{~h}$ of reaction (Scheme 46 ).

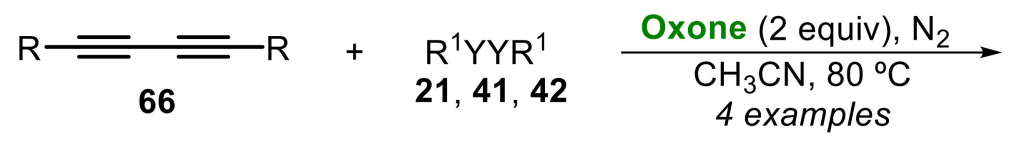

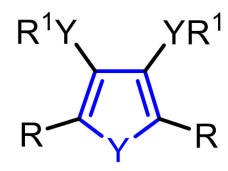

67<smiles>[R]c1ccc(-c2[se]c(-c3ccc([R])cc3)c([Se]C(C)(C)C)c2SCC(C)(C)C)cc1</smiles>

67a: $\mathrm{R}=\mathrm{H}, 78 \%, 48 \mathrm{~h}$

67b: $R=O M e, 50 \%, 2.5 \mathrm{~h}$

67c: $\mathrm{R}=\mathrm{Me}, 70 \%, 4 \mathrm{~h}$ 67d: $\mathrm{R}=\mathrm{Cl}, \mathrm{NR}, 72 \mathrm{~h}$<smiles>CCCCCc1[se]c(Br)c(Br)c1SC(C)(C)C</smiles>

67e: complex mixture, $5 \mathrm{~h}$<smiles>CCCCc1c(-c2ccc3ccccc3c2)[se]c(-c2ccc3ccccc3c2)c1S(C)(C)CC</smiles>

67f: $40 \%, 48 \mathrm{~h}$

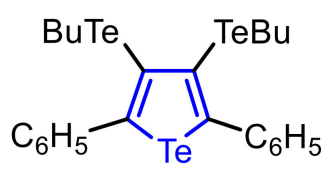

67g: NR, $72 \mathrm{~h}$

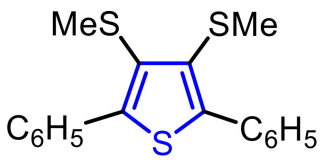

67h: NR, $72 \mathrm{~h}$

Scheme 46. Oxone/dibutyl diselenide-promoted synthesis of thiophenes 67.

On the other hand, by employing 1.5 equiv of dibutyl diselenide $21 \mathrm{f}$ and aliphatic alcohols as solvent/nucleophiles under reflux, the reaction was driven selectively to 3(butylselanyl)-4-alkoxyselenophenes 68 , that were afforded in low to very good yields (Scheme 47). Initially, several alcohols (EtOH, $\mathrm{MeOH},{ }^{i} \mathrm{PrOH}$ and $\left.{ }^{t} \mathrm{BuOH}\right)$ were employed as solvent in the presence of the 1,3-diyne 66a and dibutyl diselenide 21f. Among them, $\mathrm{EtOH}$ and $\mathrm{MeOH}$ were able to conduct the reaction adequately, affording the products $68 \mathrm{a}$ and $68 \mathrm{~b}$ at a $70 \%$ and $75 \%$ yield, respectively. On the other hand, in the presence of the sterically hindered ${ }^{i} \mathrm{PrOH}$ and ${ }^{t} \mathrm{BuOH}$, a remarkable loss of efficiency was faced, with product $65 \mathrm{c}\left(\mathrm{R}^{1}={ }^{i} \mathrm{Pr}\right)$ being obtained at a $35 \%$ yield, whereas $68 \mathrm{~d}\left(\mathrm{R}^{1}={ }^{t} \mathrm{Bu}\right)$ could not be obtained. Different symmetrical 1,3-diynes 66 where employed as substrate in the reaction with dibutyl diselenide $21 \mathrm{f}$ in the presence of $\mathrm{EtOH}$, affording the products 68e-i. For instance, the electron-rich methoxy-derivative diyne $\left(\mathrm{R}=4-\mathrm{MeOC}_{6} \mathrm{H}_{4}\right)$ afforded 68e in just $35 \%$ yield, whereas the $p$-tolyl analogue $\left(\mathrm{R}=4-\mathrm{MeC}_{6} \mathrm{H}_{4}\right)$ was a more suitable substrate, affording $68 \mathrm{f}$ in $80 \%$ yield. On the other hand, no product $68 \mathrm{~g}$ was observed when the para-chlorophenyl ring was attached to the 1,3-diyne $\left(\mathrm{R}=4-\mathrm{ClC}_{6} \mathrm{H}_{4}\right)$. When the sterically hindered ortho-substituted diynes 66e $\left(\mathrm{R}=2-\mathrm{MeC}_{6} \mathrm{H}_{4}\right)$ and $66 \mathrm{f}\left(\mathrm{R}=2-\mathrm{ClC}_{6} \mathrm{H}_{4}\right)$ were used, the respective 4-ethoxyselenophenes $68 \mathrm{~h}$ and $68 \mathrm{i}$ were obtained both at a $15 \%$ yield after $72 \mathrm{~h}$. Alkyl-substituted 1,3-diyne (66e, $\left.\mathrm{R}={ }^{n} \mathrm{Bu}\right)$ and hexa-2,4-diyne-1,6-diol (66h, $\mathrm{R}=\mathrm{CH}_{2} \mathrm{OH}$ ) afforded a complex mixture of products, not yielding the respective selenophenes $68 \mathbf{j}$ and $\mathbf{6 8 k}$. As observed above, in the reactions in acetonitrile (Scheme 42), dibutyl telluride $41 \mathrm{~d}$ and dimethyl disulfide $\mathbf{4 2 b}$ were not suitable dichalcogenides in this reaction, and the formation of products 681 and $68 \mathrm{~m}$ was not observed, even after $48 \mathrm{~h}$ (Scheme 47). 


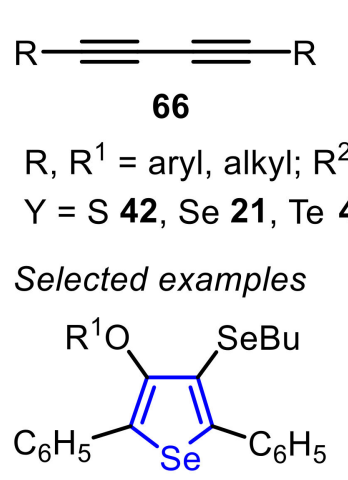

68a: $\mathrm{R}^{1}=\mathrm{Et}, 70 \%, 24 \mathrm{~h}$

68b: $\mathrm{R}^{1}=\mathrm{Me}, 75 \%, 24 \mathrm{~h}$

68c: $\mathrm{R}^{1}={ }^{i} \mathrm{Pr}, 35 \%, 72 \mathrm{~h}$

68d: $\mathrm{R}^{1}={ }^{t} \mathrm{Bu}, \mathrm{NR}, 72 \mathrm{~h}$

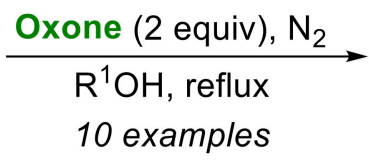

10 examples<smiles>[R]c1[se]c([R])c([R2])c1[R]</smiles>

68<smiles>[R]c1[se]c([R])c([Se]C(C)C)c1OCC</smiles>

68j: $\mathrm{R}=\mathrm{Bu}$, complex mixture, $24 \mathrm{~h}$

68e: $\mathrm{R}=\mathrm{OMe}, 35 \%, 2 \mathrm{~h}$

68f: $R=M e, 80 \%, 4 h$

68g: $\mathrm{R}=\mathrm{Cl}, \mathrm{NR}, 72 \mathrm{~h}$<smiles>[R]c1ccccc1-c1[se]c(-c2ccccc2[R])c(SCCC)c1OCC</smiles>

68h: $\mathrm{R}=\mathrm{Me}, 15 \%, 72 \mathrm{~h}$

68i: $\mathrm{R}=\mathrm{Cl}, 15 \%, 72 \mathrm{~h}$

68k: $\mathrm{R}=\mathrm{CH}_{2} \mathrm{OH}$, complex mixture, $48 \mathrm{~h}$

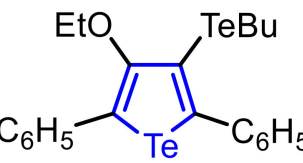<smiles>CCCCCCc1sc(CCCCC)c(OCC)c1C</smiles>

68I: NR, $48 \mathrm{~h}$

68m: NR, $48 \mathrm{~h}$

Scheme 47. Oxone/dibutyl diselenide-promoted synthesis of thiophenes 68 .

The same strategy was used by some of us to access selectively selenophene-fused benzo[b]chalcogenophenes $\mathbf{7 0}$, through the intramolecular cyclization of ortho-1,3-diynyl phenyl chalcogenides 69 (Scheme 48) [49]. The optimal conditions were efficiently applied to substituted 1,3-diynes 69 bearing electron-neutral and electron-rich aryl groups, to produce the products $\mathbf{7 0} \mathbf{a}-\mathbf{d}$ at excellent yields. Good results were obtained even in the presence of a chlorine a the ortho-position, giving the product 70d was obtained in $85 \%$ yield. Interesting, symmetric ortho-thiosubstituted 1,3-diyne $69 \mathbf{e}$ was a suitable substrate, being satisfactorily converted to $3,3^{\prime}$-bis(butylselanyl)-2,2'-dibenzo[b]thiophene 70 e in $77 \%$ yield, after $3 \mathrm{~h}$. Additionally, unsymmetric [2-(phenylbuta-1,3-diin-1-yl)phenyl](propyl)sulfide $69 \mathrm{f}$ reacted smoothly to produce the respective selenophene $70 \mathrm{f}$ in $85 \%$ yield, after $1 \mathrm{~h}$. The electron-rich substrate $69 \mathrm{~g}\left(\mathrm{R}^{1}=4-\mathrm{MeC}_{6} \mathrm{H}_{4}\right)$ was more reactive in comparison with the electron-deficient one $69 \mathrm{~h}\left(\mathrm{R}^{1}=4-\mathrm{ClC}_{6} \mathrm{H}_{4}\right)$, and the respective products $70 \mathrm{~g}$ and $70 \mathrm{~h}$ were obtained at a $80 \%$ and $70 \%$ yield, after 2 and $3 \mathrm{~h}$, respectively (Scheme 48 ).

In 2019, some of us reported the Oxone/diselenide-promoted electrophilic cyclization of 2-functionalized chalcogenoalkynes 71, allowing the access to benzo[b]chalcogenophenes 72, in moderate to excellent yields (Scheme 49) [50]. It is important to highlight the high substrate tolerance presented by the method, allowing the use of alkynes with different alkyl, or electron-rich and electron-deficient aryl substituents. 


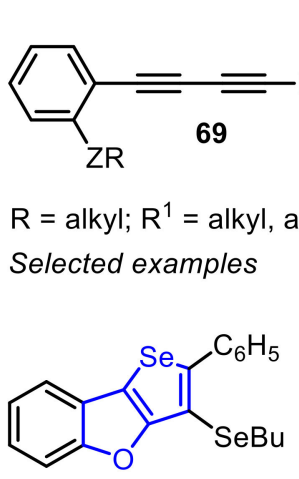

70a: 93\%, $1.0 \mathrm{~h}$

\section{$\underset{\mathrm{MeCN}, 80^{\circ} \mathrm{C}}{\stackrel{\text { Oxone }(2 \text { equiv })}{\longrightarrow}}$ \\ open flask \\ 15 examples}

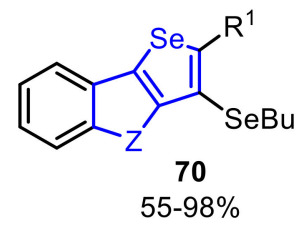

$55-98 \%$<smiles>CCCCc1c(-c2ccc(OC)cc2)[se]c2c1oc1ccccc12</smiles>

70b: $98 \%, 0.8 \mathrm{~h}$<smiles>CCCCc1c(-c2ccc(Cl)cc2)[se]c2c1oc1ccccc12</smiles>

70c: $83 \%, 1.5 \mathrm{~h}$<smiles>CCCCc1c(-c2ccccc2Cl)[se]c2c1oc1ccccc12</smiles>

70d: $85 \%, 2.5 \mathrm{~h}$<smiles>CCCCc1c(-c2sc3ccccc3c2C(C)C)sc2ccccc12</smiles>

70e: $77 \%, 3.0 \mathrm{~h}$<smiles>CCCCc1[se]c2c(sc3ccccc32)c1C(CCCC)CCCC</smiles>

70f: $85 \%, 1.0 \mathrm{~h}$<smiles>CCCCc1c(-c2ccc(C)cc2)[se]c2c1sc1ccccc12</smiles>

$70 \mathrm{~g}: 80 \%, 2.0 \mathrm{~h}$<smiles>CCCCc1c(-c2ccc(C)cc2)[se]c2c1sc1ccccc12</smiles>

70h: $70 \%, 3.0 \mathrm{~h}$<smiles>CCCCCCc1[se]c2c(sc3ccccc32)c1[Se]CCC</smiles>

70i: $55 \%, 1.0 \mathrm{~h}$

Scheme 48. Oxone/dibutyl diselenide-promoted intramolecular cyclization of ortho-1,3-diynyl phenyl chalcogenide 69.<smiles>[R][X]C#Cc1ccccc1[R1]</smiles>

71<smiles>[R][Sb][R19]</smiles>
21

$\mathrm{Z}=\mathrm{S} ; \mathrm{R}^{1}={ }^{n} \mathrm{Pr}$

$Z=O ; R^{1}=M e$

$\mathrm{Z}=\mathrm{Se} ; \mathrm{R}^{1}={ }^{n} \mathrm{Bu}$

$\mathrm{Y}=\mathrm{S}, \mathrm{Se}$

$\mathrm{R}, \mathrm{R}^{2}=$ alkyl, aryl

$\underset{\mathrm{EtOH}, \mathrm{Ar} \text {, reflux }}{\stackrel{\text { Oxone }(1.0 \text { equiv })}{\longrightarrow}}$ 0.5-3 h

22 examples<smiles>[R][R5]c1c([R])[Z]c2ccccc12</smiles>

72

$42-95 \%$

Selected examples<smiles>[R][R3]c1sc2ccccc2c1[Se]c1ccc([R])cc1</smiles>

72a: $R=R^{1}=H, 95 \%, 0.5 h$

72b: $\mathrm{R}=\mathrm{H} ; \mathrm{R}^{1}=\mathrm{OMe}, 46 \%, 2.5 \mathrm{~h}$<smiles>[R]c1ccc([Se]c2c([Se])oc3ccccc23)cc1</smiles>

72g: $\mathrm{R}=\mathrm{H}, 89 \%, 0.5 \mathrm{~h}$

72h: $R=$ OMe, $42 \%, 1.5 \mathrm{~h}$<smiles>Pc1ccc([Se]c2c([As])sc3ccccc23)cc1</smiles>

72c: $\mathrm{R}=\mathrm{H}, 93 \%, 0.5 \mathrm{~h}$ 72d: $\mathrm{R}=\mathrm{Cl}, 65 \%, 2 \mathrm{~h}$

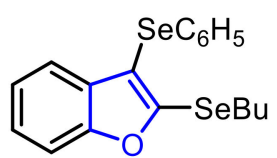

72i: $70 \%$<smiles>[R]c1ccc([Se]c2c([Se]C(C)C)oc3ccccc23)cc1</smiles>

72e: $\mathrm{R}=\mathrm{H}, 85 \%, 0.5 \mathrm{~h}$ 72f: $\mathrm{R}=\mathrm{Cl}, 68 \%, 2 \mathrm{~h}$<smiles>[R]c1ccc([Se]c2c([Se]c3ccccc3)[se]c3ccccc23)cc1</smiles>

72j: $R=M e, 94 \%, 2 \mathrm{~h}$

72k: $R=F, 71 \%, 3 h$

Scheme 49. Oxone/diselenide-promoted electrophilic cyclization of 2-functionalized chalcogenoalkynes 71. 


\section{Miscellaneous Cyclizations}

Besides the several important transformations discussed above, many other Oxonepromoted cyclization processes have been described during the last few years, to prepare a wide variety of compounds.

In 2014, Punniyamurthy and co-workers described the use of Oxone as a green oxidant in the organocatalytic synthesis of 2-arylbenzoxazoles 73 and 2-arylbenzothiazoles 74 (Scheme 50) [51]. In the presence of 1-iodo-4-nitrobenzene (20 mol\%) as catalyst, Oxone (1.5 equiv), TfOH (3.0 equiv) and hexafluoro-2-propanol (HFIP, $2.5 \mathrm{~mL}$ ) as solvent, $N-4$ tolylbenzamides 75 were converted to benzoxazoles 73 in poor to excellent yields, under room temperature.

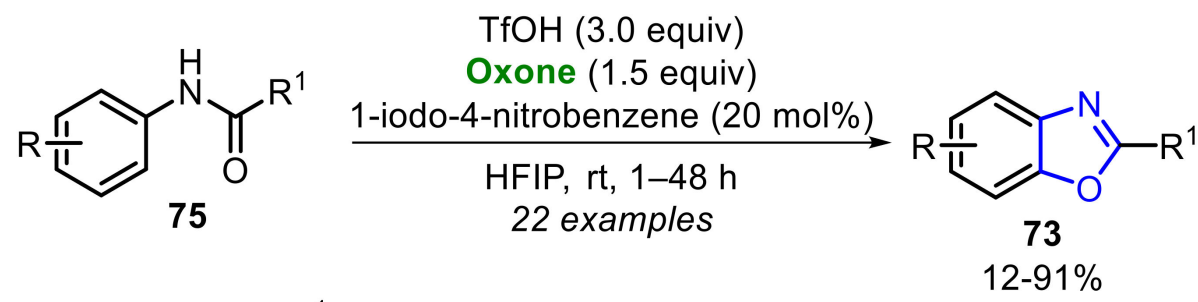

$\mathrm{R}=\mathrm{EWG}, \mathrm{EDG} ; \mathrm{R}^{1}=$ aryl, alkyl

Selected examples<smiles></smiles>

73a: $\mathrm{R}=\mathrm{C}_{6} \mathrm{H}_{5}, 12 \%, 48 \mathrm{~h}$

73b: $\mathrm{R}=3-\mathrm{OMe}, \mathrm{ND}, 48 \mathrm{~h}$

73c: $\mathrm{R}=4-\mathrm{Cl}, 91 \%, 3 \mathrm{~h}$<smiles>Cc1ccccc1-c1nc2cc(Cl)ccc2o1</smiles>

73d: $91 \%, 12 \mathrm{~h}$

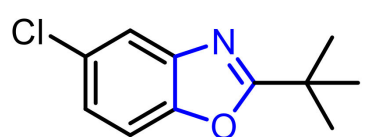

$73 e: 45 \%, 24 \mathrm{~h}$

Scheme 50. Oxone-mediated synthesis of 2-arylbenzoxazoles 73.

In parallel, several electron-rich and electron-deficient $N$-phenylthiobenzamides $\mathbf{7 6}$ were employed as substrate to access 2 -arylbenzothiazoles $\mathbf{7 4}$, under similar conditions, at room temperature (Scheme 51). The protocol showed an excellent substrate tolerance, allowing the use of different $N$-phenylthiobenzamides $\mathbf{7 6}$ to prepare a total of twenty-seven substituted benzothiazoles $\mathbf{7 4}$ in poor to excellent yields.

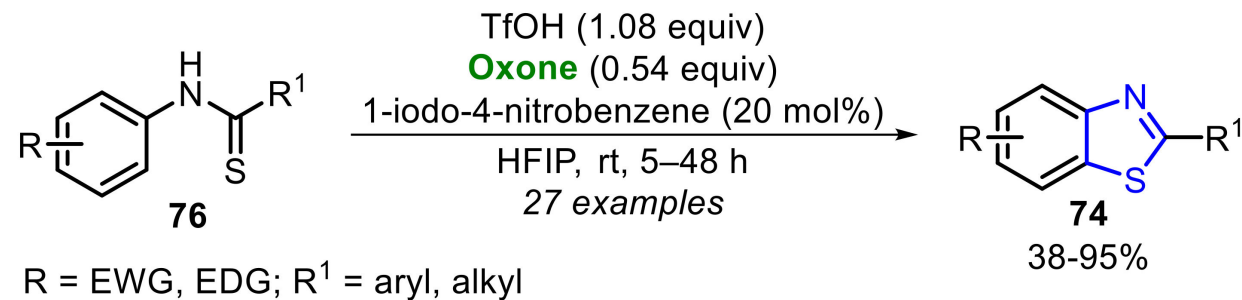

\section{Selected Examples}<smiles>[R17]Cc1nc2cc[R17]cc2s1</smiles>

74a: $\mathrm{R}=4-\mathrm{Me}, 89 \%, 12 \mathrm{~h}$

74b: $\mathrm{R}=4-\mathrm{CO}_{2} \mathrm{Et}, 38 \%, 48 \mathrm{~h}$

74c: $\mathrm{R}=4-\mathrm{NO}_{2}, \mathrm{ND}, 12 \mathrm{~h}$<smiles>Cc1ccccc1-c1nc2cc(Cl)ccc2s1</smiles>

74d: $95 \%, 12 \mathrm{~h}$<smiles>CCc1nc2cc(Cl)ccc2s1</smiles>

$74 \mathrm{e}: 63 \%, 12 \mathrm{~h}$

Scheme 51. Oxone-mediated synthesis of 2-arylbenzothiazoles 74 .

The proposed reaction mechanism starts by the generation of the hypervalent iodine(III) species II, by reaction of aryl iodide I, TfOH and Oxone (Scheme 52). The species 
II is able to catalyze the oxidative annulation of substrates $\mathbf{7 5}$ or $\mathbf{7 6}$ to produce the intermediate III, that can be stabilized by HFIP. The intramolecular cyclization of III affords the cationic intermediate $\mathbf{I V}$, releasing iodobenzene $\mathbf{I}$ to the reaction medium, which is eventually converted to II to restart the process. Finally, the intermediate IV is easily converted to the aromatic products 73 and 74 by deprotonation.

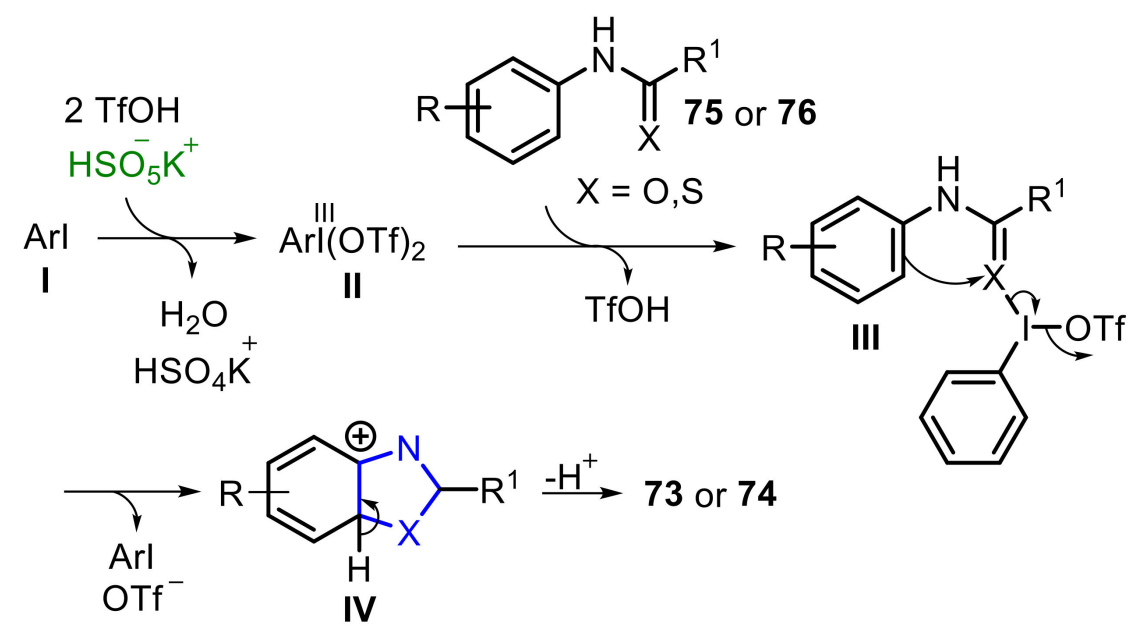

Scheme 52. Reaction mechanism for the synthesis of $\mathbf{7 3}$ and $\mathbf{7 4 .}$

Togo and co-workers described, in 2015, the Oxone/KBr-promoted bromo-lactonization of alkenyl carboxylic acids 77 and bromo-cyclization of $\mathrm{N}$-allyl amides $\mathbf{7 8}$ to provide dihydrofurans $\mathbf{7 9}$ and dihydrooxazoles $\mathbf{8 0}$, respectively (Scheme 53) [52]. The reaction optimization study revealed that $\mathrm{MeNO}_{2}$ and AcOEt, acting as solvent, remarkably increased the bromo-lactonization diastereoselectivity. In the presence of $\mathrm{MeNO}_{2}$, several substrates $\alpha, \alpha$-disubstituted 77 (gem- and vic-disubstituted alkenes) were converted to the corresponding products 79 in very good to excellent yields (Scheme 53, route A). Additionally, the six-membered ring cyclization proceeded efficiently to produce $\delta$-lactone $79 \mathrm{~b}$ at a $81 \%$ yield. The bromo-lactonization in AcOEt presented similar behavior, except to access the six-membered ring derivative $\mathbf{7 9 b}$, in which no product was observed. Subsequently, the bromo-lactonization of $\alpha$-substituted $N$-allyl amides 78 was investigated, and both $\mathrm{MeNO}_{2}$ and AcOEt, were able to produce the desired products $\mathbf{8 0}$ at very good to excellent yields (Scheme 53route B).

The Oxone/NBS-promoted synthesis of 2-aminobenzimidazoles 81 and 2-aminobenzoxazoles 82 was reported in 2016, by Kumar and co-workers, starting from cyclohexanone 83 and guanidine/urea 84 as substrates (Scheme 54) [53]. The Oxone/NBS system promoted the in situ halogenation of cyclohexanone 83, which reacted with electron-rich and electrondeficient guanidine/urea $\mathbf{8 4}$, affording the respective products $\mathbf{8 1}$ and $\mathbf{8 2}$ at good to excellent yields. The whole features of this strategy make it a simple and economical approach to prepare 2-aminobenzimidazoles 81 and 2-aminobenzoxazoles 82 .

In 2016, Sawant and co-workers have reported a Ru-catalyzed Oxone-mediated intramolecular $\mathrm{C}-\mathrm{S}$ coupling of $\mathrm{N}$-arylthioureas 85 , aiming to access 2 -aminobenzothiazoles 86 (Scheme 55) [54]. A good substrate tolerance was achieved, allowing the synthesis of a wide library of 2-aminobenzothiazoles $\mathbf{8 6}$ in poor to excellent yields. In general, electron-rich $\mathrm{N}$-arylthioureas 85 were more reactive in relation to the electron-poor ones. An example of this remarkable difference can be observed by comparing the access to the products 86e $\left(\mathrm{R}^{1}=\mathrm{OMe}\right)$ and $86 \mathrm{f}\left(\mathrm{R}^{1}=\mathrm{NO}_{2}\right)$, which were obtained at a $91 \%$ and $13 \%$ yield, respectively. This specific reactivity indicates the involvement of an electrophilic ruthenation mechanistic pathway, which is supported by the observed inverse secondary kinetic isotopic effect (KIE) effect and by the computational studies. 


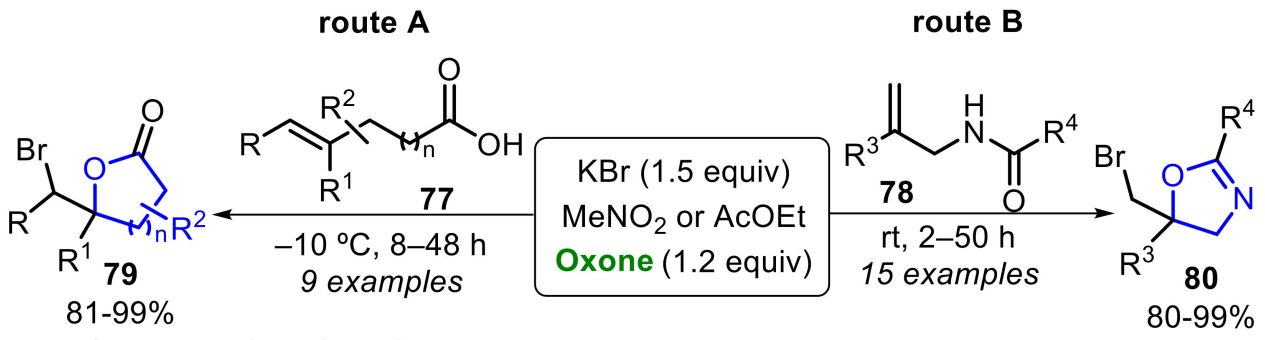

$\mathrm{R}=\mathrm{R}^{2}=$ alkyl; $\mathrm{R}^{1}=\mathrm{R}^{3}=\mathrm{R}^{4}=$ aryl, alkyl

Selected examples from route $A$<smiles>CC1(C)CC(CBr)OC1=O</smiles>

79a:

$\mathrm{MeCO}_{2}: 99 \%, 12 \mathrm{~h}$ AcOEt: $95 \%, 12 \mathrm{~h}$<smiles>O=C1CCCC(CBr)O1</smiles>

79b:<smiles>O=C1C[C@H]2CCC[C@@H](Br)[C@H]2O1</smiles>

79c:<smiles>CC1(CBr)CCC(=O)O1</smiles>

79d:

$\mathrm{MeCO}_{2}: 99 \%, 12 \mathrm{~h}$ AcOEt: $98 \%, 24 \mathrm{~h}$

Selected examples from route $B$

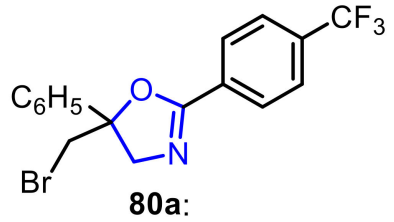

$\mathrm{MeCO}_{2}: 99 \%, 2 \mathrm{~h}$ AcOEt: $92 \%, 9 \mathrm{~h}$<smiles>CCCCCCCCCCCCCCC1(c2ccc(OC)cc2)CN=C(CBr)O1</smiles>

80b:

$\mathrm{MeCO}_{2}: 81 \%, 2 \mathrm{~h}$ AcOEt: $87 \%, 50 \mathrm{~h}$

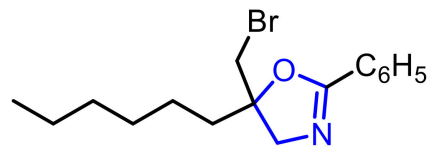

$80 \mathrm{c}:$

$\mathrm{MeCO}_{2}: 80 \%, 2 \mathrm{~h}$ AcOEt: $98 \%, 50 \mathrm{~h}$

Scheme 53. Oxone/KBr-promoted bromo-cyclization of alkenyl carboxylic acids 77 (A) and $N$-allyl amides 78 (B).<smiles>O=C1CCCCC1</smiles>

83

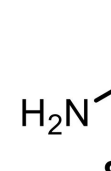

84
PTSA $(1.7 \mathrm{mmol})$

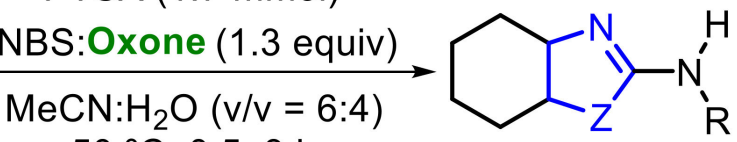
$50{ }^{\circ} \mathrm{C}, 0.5-3 \mathrm{~h}$ 16 examples
81 and 82

$78-95 \%$

$\mathrm{Z}=\mathrm{OH}, \mathrm{NH} ; \mathrm{R}=\mathrm{H}, \mathrm{C}_{6} \mathrm{H}_{5}, 4-\mathrm{ClC}_{6} \mathrm{H}_{4}, 4-\mathrm{BrC}_{6} \mathrm{H}_{4}, 4-\mathrm{NO}_{2} \mathrm{C}_{6} \mathrm{H}_{4}$,

$3-\mathrm{ClC}_{6} \mathrm{H}_{4}, 3-\mathrm{NO}_{2} \mathrm{C}_{6} \mathrm{H}_{4}$

\section{Selected examples}<smiles>[R]NC1=NC2CCCCC2N1</smiles>

81a: $R=H, 95 \%, 0.5 h$

81b: $\mathrm{R}=4-\mathrm{CIC}_{6} \mathrm{H}_{4}, 91 \%, 1.5 \mathrm{~h}$

81c: $\mathrm{R}=3-\mathrm{NO}_{2} \mathrm{C}_{6} \mathrm{H}_{4}, 84 \%, 2 \mathrm{~h}$<smiles>[R]NC1=NC2CCCCC2O1</smiles>

82a: $\mathrm{R}=\mathrm{H}, 93 \%, 2 \mathrm{~h}$

82b: $\mathrm{R}=4-\mathrm{MeOC}_{6} \mathrm{H}_{4}, 90 \%, 2 \mathrm{~h}$

82c: $\mathrm{R}=3-\mathrm{NO}_{2} \mathrm{C}_{6} \mathrm{H}_{4}, 78 \%, 3 \mathrm{~h}$

Scheme 54. Oxone/NBS-promoted synthesis of 2-aminobenzimidazoles 81 and 2-aminobenzoxazoles 82. 
<smiles>[R]c1c([R])c([R])c(NC(=S)N([R7])[R5])c([2H])c1[R]</smiles>

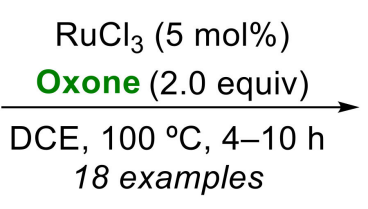<smiles>[R]c1c([R])c([R])c2sc(N([R7])[R18])nc2c1[R19]</smiles>

$\mathrm{R}=\mathrm{Cl}, \mathrm{Br}, \mathrm{I} ; \mathrm{R}^{1}=\mathrm{H}, \mathrm{OMe}, \mathrm{NO}_{2} ; \mathrm{R}_{2}=\mathrm{H}, \mathrm{F}, \mathrm{Cl}, \mathrm{Br}, \mathrm{OMe}, \mathrm{NO}_{2}, \mathrm{Et}, \mathrm{CO}_{2} \mathrm{Me}$ $\mathrm{R}^{3}=\mathrm{H}, \mathrm{Cl} ; \mathrm{R}^{4}=\mathrm{C}_{6} \mathrm{H}_{5}$, heteroaryl; $\mathrm{R}^{5}=\mathrm{H}$, heteroaryl<smiles>[R]c1ccc2nc(N3CCOCC3)sc2c1</smiles>

86a: $R^{2}=H, 87 \%$

86b: $R^{2}=E t, 71 \%$

86c: $R^{2}=$ OMe, $85 \%$

86d: $R^{2}=\mathrm{NO}_{2}, 79 \%$<smiles>[R]c1cc([R])c2sc(N3CCOCC3)nc2c1</smiles>

86e: $R^{1}=O M e ; R^{3}=H, 91 \%$

86f: $R^{1}=\mathrm{NO}_{2} ; R^{3}=\mathrm{H}, 13 \%$

86g: $R^{1}=H ; R^{3}=\mathrm{Cl}, 69 \%$

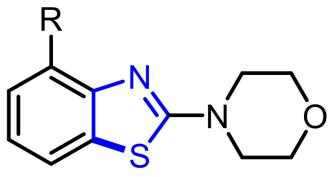

86h: $\mathrm{R}=\mathrm{Cl}, 64 \%$

$86 \mathbf{i}: \mathrm{R}=\mathrm{Br}, 78 \%$

86j: $R=I, 55 \%$<smiles>c1ccc(Nc2nc3ccccc3s2)cc1</smiles>

86k: $82 \%$

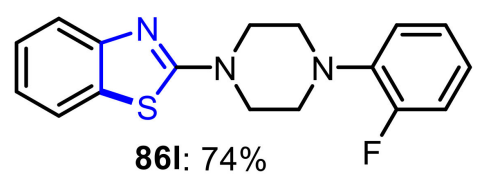

86I: $74 \%$<smiles>COc1ccc2nc(Nc3ccc(F)c(Cl)c3)sc2c1</smiles>

Scheme 55. Ru-catalyzed Oxone-mediated intramolecular C-S coupling of $N$-arylthioureas 85.

In 2018, Sasai and co-workers developed a Pd(II)-catalyzed Oxone-mediated enantioselective $a z a$-Wacker type reaction of alkenyl sulfonamides 87 , to afford several substituted heterocyclic systems $\mathbf{8 8}$, including morpholines, piperazines and piperidines, as well as their benzo-fused derivatives (Scheme 56) [55]. Electron-rich and electron-deficient alkenyl sulfonamides $\mathbf{8 7}$ were adequately employed as substrates to access the products $\mathbf{8 8 b} \mathbf{b}$, and any remarkable difference on reactivity was observed. The presence of the phenylene binder in the starting material was not mandatory, and the products $\mathbf{8 8 f} \mathbf{f}-\mathbf{h}$ were satisfactorily obtained. Limitations were found when trisubstituted alkenes 87 were used, and the

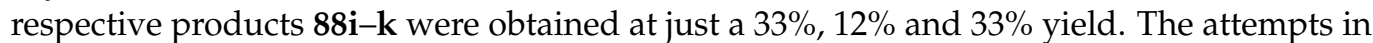
preparing the benzo[b][1,4] oxazepine $\mathbf{8 8 1}$ were not successful (Scheme 56 ).

In 2018, Imai and Togo reported an Oxone-mediated synthesis of 3-arylisoxazole4,5-dicarboxylates 89 , through the one-pot reaction between benzylic chlorides 80 or alkyl 4-tosylates 91, and acetylenedicarboxylate 50p (Scheme 57) [56]. The substrates 90 and 91 were treated with $N$-methylmorpholine $N$-oxide (NMO, 4 equiv), and then with hydroxylamine hydrochloride (1.2 equiv) and potassium carbonate ( 0.6 equiv), followed by the addition of acetylenedicarboxylate $50 p$, to generate desired products 89 . The method efficiency was proved by accessing a library of twenty-three new isoxazoles 89 at up to a $97 \%$ yield and in short reaction times.

The study was extended to different acetylene derivatives $\mathbf{5 0}$ in the reaction with 4chlorobenzyl chloride $90 \mathrm{a}$, and the desired isoxazoles $89 \mathrm{~h}-\mathrm{m}$ were obtained at moderate to good yields (Scheme 58). As previously observed, a good substrate tolerance was afforded, allowing the application of electron-rich and electron-deficient acetylenes $\mathbf{5 0 .}$

Bhatt and co-workers reported, in 2019, a Cu(II)-catalyzed Oxone-mediated one-pot synthesis of 3,5-diarylisoxazoles $\mathbf{9 2}$, starting from $\alpha, \beta$-unsaturated ketones $\mathbf{9 3}$ and hydroxylamine hydrochloride, via an oxidative annulation reaction (Scheme 59) [57]. The protocol was successfully applied to a variety of electron-rich and electron-deficient chalcones $\mathbf{9 3}$ 
affording a wide collection of compounds 92a-o in good to excellent yields, just after a few minutes under thermal conditions (refluxing EtOH).<smiles>[R]CCC(N[Y])C([Y])C/C([R])=C(/[R])C([R])[R]</smiles>

87
$\mathrm{Pd}(\mathrm{OAc})_{2}(10 \mathrm{~mol} \%)$

$\mathrm{PhCl}$, Oxone (1.0 equiv) $(P, R, R)-i$-Pr-SPRIX (15 mol\%) $60{ }^{\circ} \mathrm{C}, 16-96 \mathrm{~h}$ 12 examples $Y=\mathrm{O}, \mathrm{CH}_{2}, \mathrm{NTs} ; \mathrm{R}=\mathrm{H}, \mathrm{Me}$
$\mathrm{R}^{1}=\mathrm{H}, \mathrm{OMe}, \mathrm{CF}_{3}, \mathrm{Br} ; \mathrm{R}^{2}=\mathrm{H}, \mathrm{Me}$<smiles>[Y5]N1C2=C(C=C[Se]C=C2)OC[C@H]1C=C</smiles>

88a: $R=H, 84 \%$

88b: $R=4-\mathrm{OMe}, 53 \%$

88c: $R=4-\mathrm{CF}_{3}, 43 \%$

88d: $R=4-B r, 36 \%$

88e: $R=5-M e, 54 \%$<smiles>CC(C)=C[C@@H]1COc2ccccc2N1S</smiles>

88k: $33 \%$<smiles>C=C[C@@H]1C[Y]CCN1S</smiles>

88f: $Y=O, 30 \%$

88g: $Y=\mathrm{CH}_{2}, 68 \%$

88h: $Y=N, 61 \%$<smiles>C=CC1CCOc2ccccc2N1[N+](=O)[O-]</smiles>

88I: ND

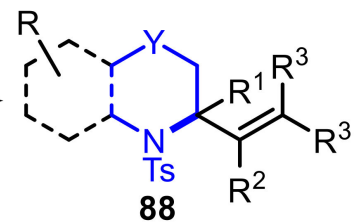

$12-84 \%$

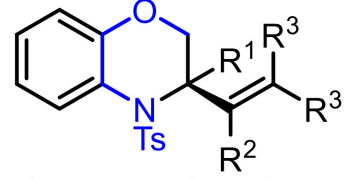

88i: $R^{1}=C_{3}, R^{2}=R^{3}=H, 33 \%$

88j: $R^{1}=R^{3}=H, R^{2}=$ Me, $12 \%$

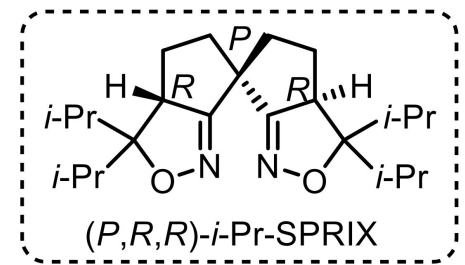

Scheme 56. $\mathrm{Pd}(\mathrm{II})$-catalyzed Oxone-mediated enantioselective $a z a$-Wacker type reaction.
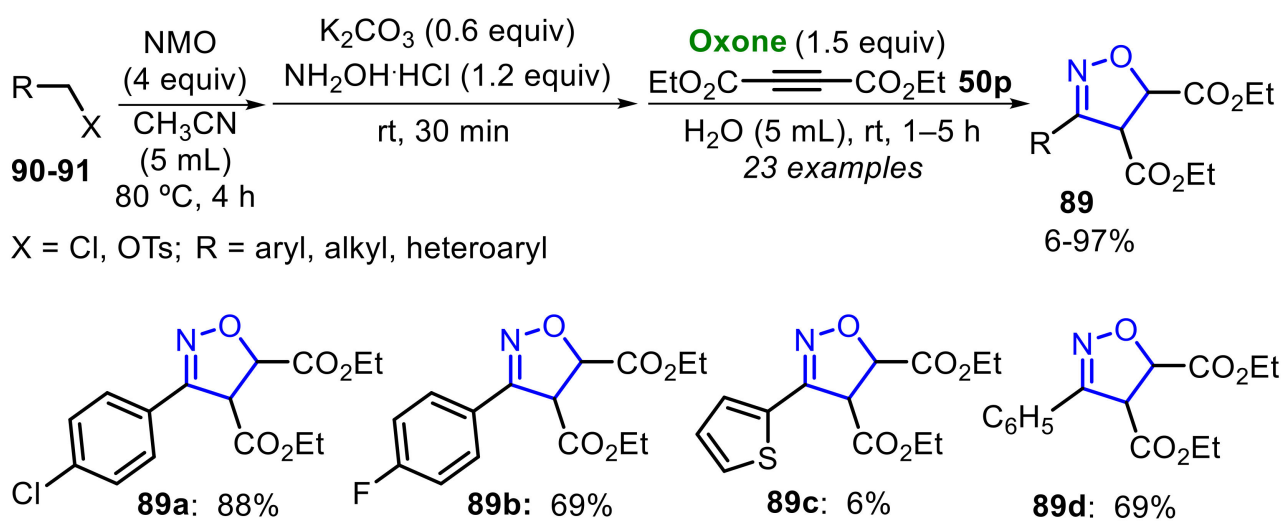<smiles>CCOC(=O)C1ON=C(c2ccc(O)cc2)C1C(=O)OC</smiles><smiles>CCOC(=O)C1ON=C(c2ccc(C(=O)OCc3ccccc3)cc2)C1C(=O)OCC</smiles><smiles>CCOC(=O)C1ON=C(c2cc(C)nc3ccccc23)C1COC</smiles>

Scheme 57. Oxone-mediated synthesis of 3-arylisoxazole-4,5-dicarboxylates 89, through a one-pot process.

In 2019, some of us reported an Oxone/dialkyl diselenide-promoted synthesis of $5 H$ selenopheno[3,2-c] isochromen-5-ones 94, through a double intramolecular cyclization of methyl 2-(organyl-1,3-diynyl)benzoate 95 (Scheme 60) [58]. Dialkyl diselenides 21 ( $\mathrm{R}^{2}=\mathrm{Et}$, $\mathrm{Bu}$ and $\mathrm{Oct}$ ) were satisfactorily employed, giving the corresponding isochromenones $\mathbf{9 4 a - c}$ 
in good yields, whereas dibenzyl diselenide, bis(2-naphthylmethyl)diselenide, dibutyl ditelluride and dimethyl disulfide were not suitable to produce the products $\mathbf{9 4 d}, \mathbf{9 4 e}, \mathbf{9 4 f}$ and $\mathbf{9 4 g}$, respectively. Additionally, several substituted 1,3-diynes were efficiently em-

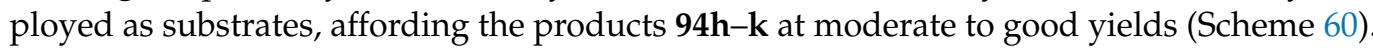

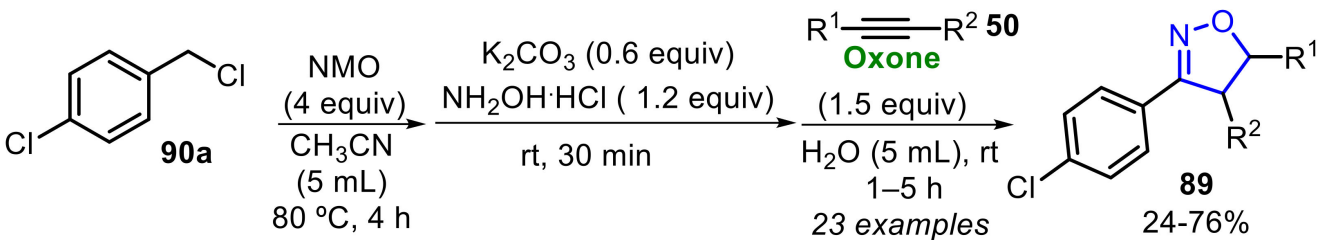

$\mathrm{R}^{1}=\mathrm{R}^{2}=\mathrm{H}$, aryl, alkyl

Selected examples<smiles>COC(=O)C1ON=C(c2ccc(Cl)cc2)C1C(C)=O</smiles><smiles>CCOC1CC(c2ccc(Cl)cc2)=NO1</smiles><smiles>Clc1ccc(C2=NOC(c3cccc(Cl)c3)C2)cc1</smiles><smiles>COc1ccc(C2CC(c3ccc(Cl)cc3)=NO2)cc1</smiles><smiles>CCCCCC1ON=C(c2ccc(Cl)cc2)C1C(C)=O</smiles><smiles>CC(C)(C)[14CH3]</smiles>

Scheme 58. Oxone-mediated synthesis of 3-arylisoxazole-4,5-dicarboxylates 89, through a one-pot process.<smiles>[R]c1ccc(/C=C/C(=O)c2ccccc2[R])cc1</smiles>

93

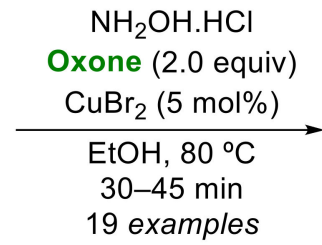

19 examples<smiles>[R]c1cccc(-c2cc(-c3ccccc3)on2)c1</smiles>

92

$\mathrm{R}=\mathrm{H}$, 4-Me, 4-OMe, 4-OEt, 2,4-Me 2 , 4-Cl, 2-Cl, 4-Br, 3,4- $\mathrm{Cl}_{2}, 4-\mathrm{NO}_{2}$

Selected examples<smiles>[R]c1ccc(-c2cc(-c3ccccc3)on2)cc1</smiles>

92a: $\mathrm{R}=\mathrm{H}, 85 \%, 30 \mathrm{~min}$

92b: $R=M e, 83 \%, 35 \mathrm{~min}$

92c: $R=$ OEt, $85 \%, 35 \mathrm{~min}$

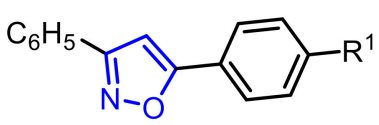<smiles>[R]c1ccc(-c2cc(-c3ccccc3)on2)cc1</smiles>

92d: $\mathrm{R}=\mathrm{Cl}, 83 \%, 35 \mathrm{~min}$

92e: $\mathrm{R}=\mathrm{Br}, 84 \%, 35 \mathrm{~min}$

92f: $\mathrm{R}=\mathrm{NO}_{2}, 79 \%, 45 \mathrm{~min}$<smiles>[R]c1cccc(-c2cc(SCCCC)no2)c1</smiles><smiles>Clc1ccccc1-c1cc(-c2ccccc2)on1</smiles>

92g, $81 \%, 40 \mathrm{~min}$<smiles>[R]c1ccccc1-c1cc(CCCCC)no1</smiles>

92h: $\mathrm{R}^{1}=\mathrm{Me}, 78 \%, 30 \min \mathbf{9 2 k}: \mathrm{R}^{1}=\mathrm{Me}, 80 \%, 30 \min \mathbf{9 2 n}: \mathrm{R}^{1}=\mathrm{Cl}, 80 \%, 40 \min$

92i: $R^{1}=\mathrm{Cl}, 83 \%, 35 \mathrm{~min} \quad$ 92I: $\mathrm{R}^{1}=\mathrm{Cl}, 81 \%, 30 \mathrm{~min} \quad$ 920: $\mathrm{R}^{1}=\mathrm{NO}_{2}, 77 \%, 40 \mathrm{~min}$

92j: $R^{1}=B r, 78 \%, 40 \min \quad 92 m: R^{1}=B r, 75 \%, 40$ min

Scheme 59. $\mathrm{Cu}(\mathrm{II})$-catalyzed Oxone-mediated one-pot synthesis of 3,5-diarylisoxazoles 92. 


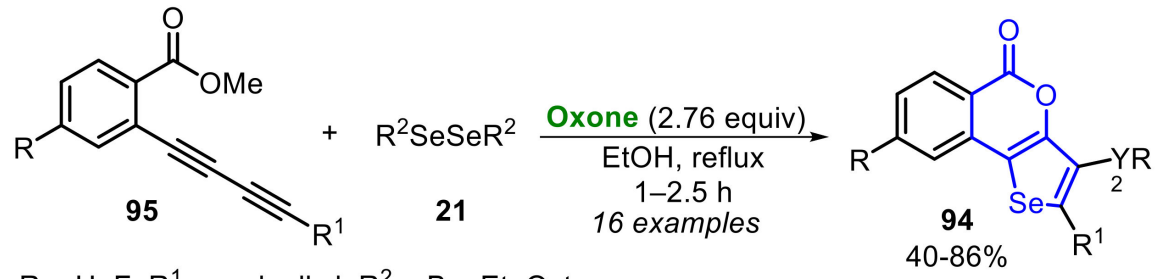

$\mathrm{R}=\mathrm{H}, \mathrm{F} ; \mathrm{R}^{1}=$ aryl, alkyl; $\mathrm{R}^{2}=\mathrm{Bu}, \mathrm{Et}$, Oct

Selected examples<smiles>[R][Se]c1c(C)[se]c2c1oc(=O)c1ccccc12</smiles>

94a: $R^{2}=B u, 86 \%$

94b: $R^{2}=E t, 77 \%$

94c: $R^{2}=$ Oct, $82 \%$<smiles>[R]c1c(CCCCC)[X]c2c1oc(=O)c1ccccc12</smiles>

94f: $Y=S, R^{2}=M e ; X=S, N R$

94g: $Y=T e, R^{2}=B u ; X=T e, N R$

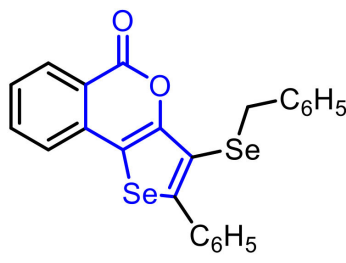

94d: NR<smiles>CCCCCCc1[se]c2c(oc(=O)c3ccccc32)c1[Se]Cc1ccc2ccccc2c1</smiles>

94e: NR<smiles>[R1]c1[se]c2c(oc(=O)c3ccccc32)c1S(C)(=O)=O</smiles>

94h: $\mathrm{R}^{1}=4-\mathrm{MeOC}_{6} \mathrm{H}_{4}, 74 \%$

94i: $\mathrm{R}^{1}=4-\mathrm{ClC}_{6} \mathrm{H}_{4}, 72 \%$

94j: $\mathrm{R}^{1}=2-\mathrm{MeOC}_{6} \mathrm{H}_{4}, 40 \%$<smiles>CCCCc1c(Br)[se]c2c1oc(=O)c1ccccc12</smiles>

94k, $73 \%$

Scheme 60. Oxone/dialkyl diselenide-promoted synthesis of $5 H$-selenopheno[3,2-c]isochromen-5ones 94.

Curiously, when 2-(2-methoxyphenylbuta-1,3-diynyl)benzoate 95d was employed as substrate, in the presence of dibutyl diselenide 21f, the expected $5 \mathrm{H}$-selenopheno[3,2c]isochromen-5-one $\mathbf{9 4} \mathbf{j}$ was isolated in only $40 \%$ yield. The low efficiency toward $\mathbf{9 4} \mathbf{j}$ is associated with the parallel formation of benzofuran derivative $\mathbf{9 4} \mathbf{j}^{\prime}$, that was obtained at a $50 \%$ yield (Scheme 61 ). This behavior is due to two competing reactions (Se-cyclization vs. $\mathrm{O}$-cyclization) of the intermediate IX, generated in the first step of the transformation (see Scheme 62, for the reaction mechanism).

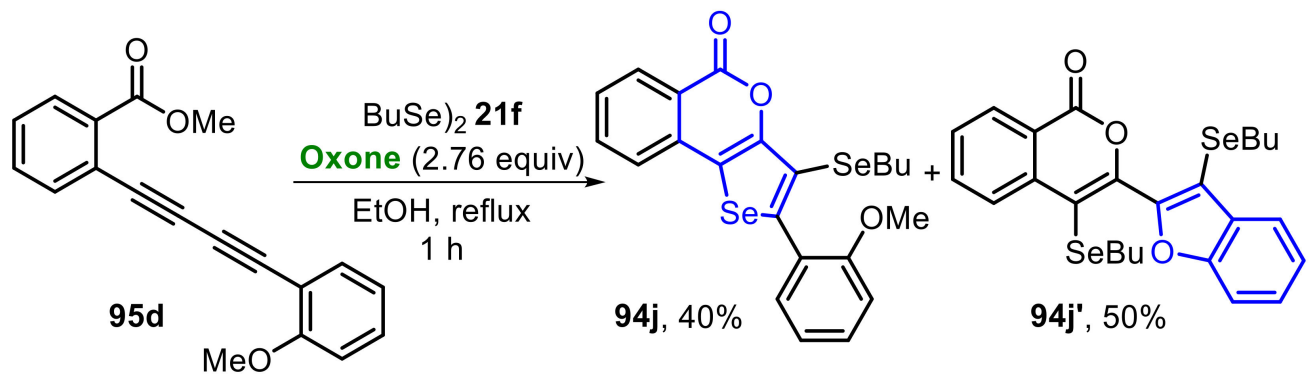

Scheme 61. Competition between Se-cyclization and $O$-cyclization of the substrate $95 \mathrm{~d}$. 
Formation of the electrophiles:

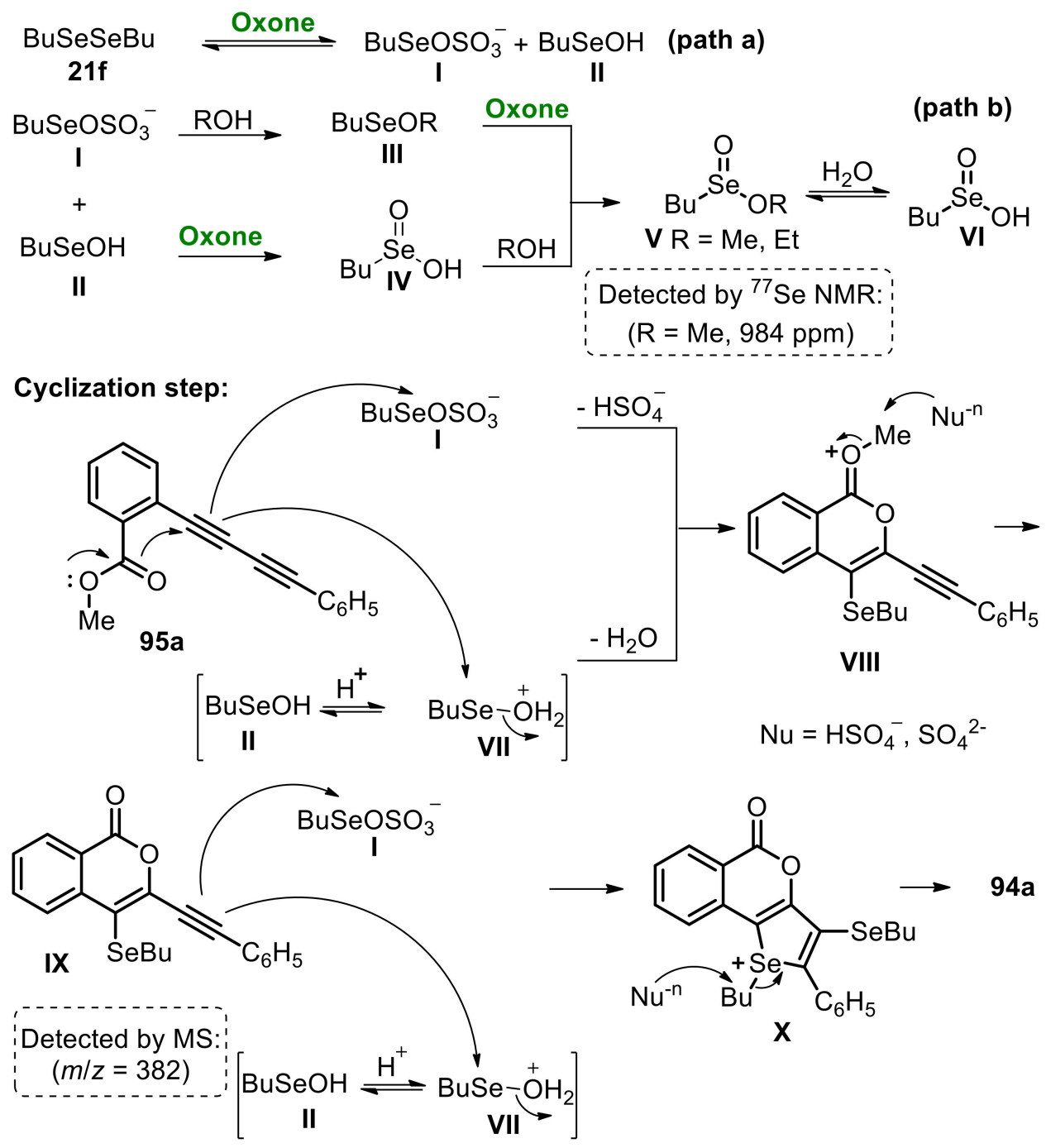

Scheme 62. Plausible reaction mechanism for the formation of the products 94 .

Based on control experiments, which were monitored by ${ }^{77}$ Se NMR and GC/MS analysis, a possible mechanism for the reaction was proposed (Scheme 62). Initially, dibutyl diselenide $21 \mathrm{f}$ reacts with Oxone to form two intermediates: $\mathrm{BuSeOSO}_{3}{ }^{-} \mathrm{I}$ and $\mathrm{BuSeOH}$ II (Scheme 62, path a). The formation of species I and II was confirmed by the formation of seleninic ester V and acid VI (Scheme 62, path b). The species II can be protonated by the reaction medium, leading to $\mathrm{BuSeOH}_{2}{ }^{+}$VII. Then, the 1,3-diyne 95a reacts with I and VII to form the cyclic intermediate VIII, releasing $\mathrm{HSO}_{4}{ }^{-}$and $\mathrm{H}_{2} \mathrm{O}$ to the reaction medium. Following, the displacement of the methyl group from VIII, by a nucleophile $\left(\mathrm{HSO}_{4}{ }^{-}\right.$and $/$or $\mathrm{SO}_{4}{ }^{2-}$ ) affords the intermediate IX (detected by mass spectrometry), that reacts similarly with $\mathbf{I}$ and VII, to produce the fused-selenophene cation intermediate $\mathbf{X}$. The displacement of the butyl group finally affords the expected product 94a (Scheme 62).

In 2020, Qiu, Liu and co-workers developed the Oxone-mediated ipso-cyclization of $\mathrm{N}$ arylpropiolamide $\mathbf{9 6}$ to access the spirocyclo derivatives $\mathbf{9 7}$ and $\mathbf{9 8}$ (Scheme 63). The reaction was conducted in the presence of $\mathrm{MeCN}: \mathrm{H}_{2} \mathrm{O}(v / v$ 4:1) as reaction medium, and the selectivity was achieved by employing different halogen sources ( $\mathrm{ZnX} \mathrm{X}_{2}$ and TBAX) [59]. In the presence of $\mathrm{ZnX}_{2}$, the spiro-tricycle $\mathbf{9 7}$ was formed, through an ortho-hydroxylative process, in moderate to good yields. By employing $N$-(2-oxopropyl)- $N, 3$-diphenylpropiolamide 96a, the formation of a mixture of the products 97 a and 98a was observed. When parasubstituted substrates $96\left(\mathrm{R}=\mathrm{C}_{6} \mathrm{H}_{5}\right.$ and $\left.\mathrm{Cl}\right)$ were used, the expected products $\mathbf{9 7} \mathbf{b}-\mathbf{c}$ were 
obtained at good yields, without formation of the ring-opened derivatives. Interestingly, the fluoro-substituted substrate $\mathbf{9 6}$ was suitable to the reaction conditions, giving the respective product 97 e at a $61 \%$ yield (Scheme 63 ).<smiles>[R7]C#CC(=O)N(CC(C)=O)c1ccc([R])cc1</smiles><smiles>[R]C1=CC2N(CC(C)(O)C1O)C(=O)C21C([R])=C([X])C(O)C1Br</smiles>

$55-77 \%$

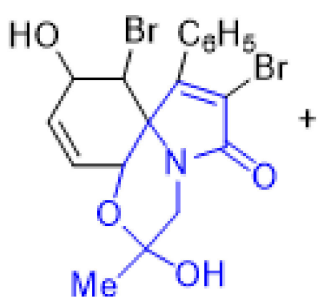

$97 a^{:} 58 \%$

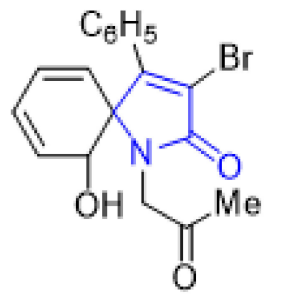

98a: $17 \%$

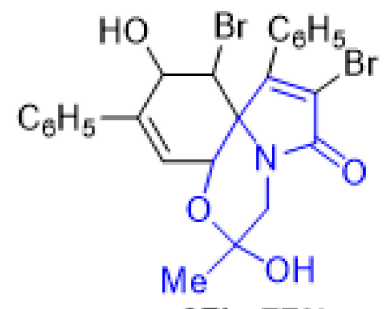

$97 \mathrm{~b}: 77 \%$<smiles>[Y6]C(C)(C)CN1C(=O)C(Br)=C(C)C12C(OC(C)(C)CCC)C=C(Cl)C(O)C2Br</smiles><smiles>CC(C)(O)CN1C(=O)C(Cl)=C(c2ccccc2Cl)C12C(Cl)C=CC(O)C2Cl</smiles>

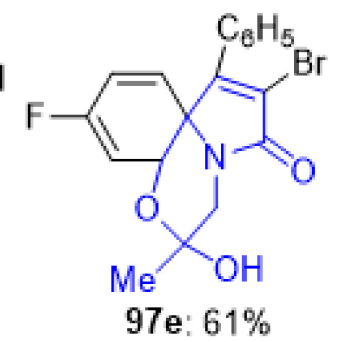

Scheme 63. Oxone-mediated ipso-cyclization of $\mathrm{N}$-arylpropiolamide 93 to access the spirocyclo derivatives 97.

Due to the poor stability of spiro-tricycles 97 , authors have focused their attention on the synthesis of ring-opened products 98 , that were accessed by employing TBAX as halogen source, and the protocol was extended to $N$-arylpropiolamide 96 bearing different $R, R^{1}$ and $R^{2}$ substituents (Scheme 64 ). The $R$ group can be replaced by a cyclopropyl ketone, ethyl ketone, ${ }^{t}$ butyl ketone, and several aryl ketones, giving a range of orthohydroxy spirocycles $98 \mathbf{a} \mathbf{h}$ in $46-88 \%$ yields. Additionally, the substituent $\mathrm{R}^{1}$ can be easily replaced by aryl or heteroaryl groups, leading to the respective products $\mathbf{9 8 i} \mathbf{i} \mathbf{l}$ in good yields. By employing the para-alkynyl $N$-arylpropiolamide 96 , the product $98 \mathrm{~m}$ was obtained at only a $47 \%$ yield. Moreover, TBAI has also demonstrated to be efficient, allowing the synthesis of the compound $98 \mathrm{n}$ at a $69 \%$ yield.

In 2020, some of us described the Oxone/diselenide-promoted ultrasound-assisted selective cyclization of unsaturated oximes 99 , to access 5-methylselanyl-4,5-dihydroisoxazoles 100 (Scheme 65) [60]. The sonication was crucial to drive the process selectively, in short reaction times, giving the products $\mathbf{1 0 0}$ in moderate to excellent yields. Several oximes 99 and diselenides 21, bearing electron-donating or electron-withdrawing groups, were satisfactorily employed, proving the applicability and substrate tolerance of the method. 
<smiles>[R]C#CC(=O)N(CC([R])=O)c1ccc([R])cc1</smiles>

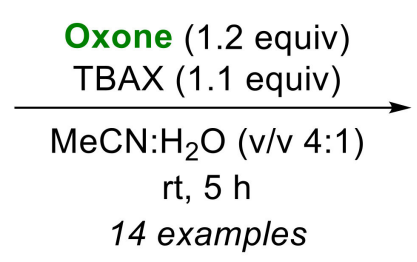<smiles>[R]C(=O)CN1C(=O)C([X])=C([R])C12C=CC([R])=CC2[R5]</smiles><smiles>[R]C(=O)CN1C(=O)C(Br)=C(c2ccccc2)C12C=CC=CC2O</smiles>

98a: $R=M e, 80 \%$

98b: $R=$ cyclopropyl, $88 \%$

98c: $R=E t, 65 \%$

98d: $R={ }^{t} \mathrm{Bu}, 51 \%$

98e: $\mathrm{R}=\mathrm{C}_{6} \mathrm{H}_{5}, 68 \%$

98f: $\mathrm{R}=4-\mathrm{MeC}_{6} \mathrm{H}_{4}, 72 \%$

98g: $\mathrm{R}=4-\mathrm{MeOC}_{6} \mathrm{H}_{4}, 59 \%$<smiles>CC(=O)CN1C(=O)C(Br)=C(c2ccccc2)C12C=CC(C#Cc1ccccc1)=CC2O</smiles>

98h: $\mathrm{R}=2$-napthalenyl, $46 \%$<smiles>[R1]C1=C(Br)C(=O)N(CC(C)=O)C12C=CC=CC2O</smiles>

98i: $\mathrm{R}^{1}=4-\mathrm{MeOC}_{6} \mathrm{H}_{4}, 83 \%$

98j: $\mathrm{R}^{1}=4-\mathrm{MeC}_{6} \mathrm{H}_{4}, 79 \%$

98k: $\mathrm{R}^{1}=2$-thiophenyl, $73 \%$

98I: $R^{1}=1$-napthalenyl, $64 \%$

98n: $69 \%$<smiles>CC(=O)CN1C(=O)C(I)=C(c2ccccc2)C12C=CC=CC2O</smiles>

Scheme 64. Oxone-mediated ipso-cyclization of $N$-arylpropiolamide 96 to access the spirocyclo derivatives 98

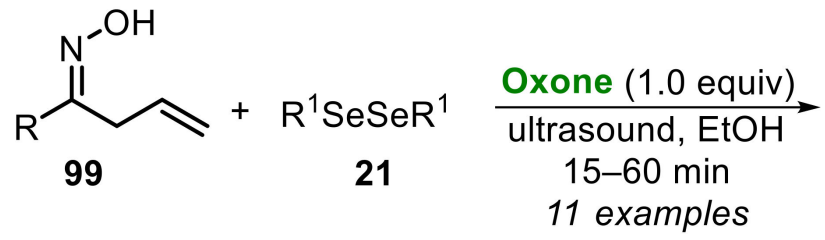<smiles></smiles><smiles>[R1][Se]CC1CC([AsH2])=NO1</smiles>

100a: $\mathrm{R}^{1}=\mathrm{C}_{6} \mathrm{H}_{5}, 85 \%, 30 \mathrm{~min}$ 100b: $\mathrm{R}^{1}=4-\mathrm{ClC}_{6} \mathrm{H}_{4}, 93 \%, 20 \mathrm{~min}$ 100c: $\mathrm{R}^{1}=4-\mathrm{FC}_{6} \mathrm{H}_{4}, 85 \%, 30 \mathrm{~min}$ 100d: $\mathrm{R}^{1}=4-\mathrm{MeC}_{6} \mathrm{H}_{4}, 72 \%, 20 \mathrm{~min}$ 100e: $\mathrm{R}^{1}=4-\mathrm{MeOC}_{6} \mathrm{H}_{4}, 60 \%, 15 \mathrm{~min}$ 100f: $\mathrm{R}^{1}=2$-naphthyl, $82 \%, 20 \mathrm{~min}$ 100g: $\mathrm{R}^{1}={ }^{n} \mathrm{Bu}, 85 \%, 40 \mathrm{~min}$<smiles></smiles>

100h: $\mathrm{R}=4-\mathrm{ClC}_{6} \mathrm{H}_{4}, 70 \%, 30 \mathrm{~min}$ 100i: $\mathrm{R}=4-\mathrm{FC}_{6} \mathrm{H}_{4}, 80 \%, 35 \mathrm{~min}$ 100j: $\mathrm{R}=4-\mathrm{MeC}_{6} \mathrm{H}_{4}, 72 \%, 30 \mathrm{~min}$ 100k: $\mathrm{R}=2$-naphthyl, $75 \%, 40 \mathrm{~min}$

Scheme 65. Oxone/diselenide-promoted ultrasound-assisted selective cyclization of unsaturated oximes 99.

A comparison study, employing different energy sources (conventional heating, microwave and ultrasound irradiation) was conducted by the authors. Under ultrasound irradiation the process followed a radical pathway, as verified by control experiments. On the other hand, by employing conventional heating $\left(65^{\circ} \mathrm{C}\right)$ or microwave irradiation, the transformation followed an ionic pathway. Regarding the radical pathway, the first step is 
the formation of the hydroxyl radical $\left(\mathrm{HO} \bullet\right.$ ) and the radical species $\bullet \mathrm{OSO}_{3} \mathrm{~K}$, through the US-promoted Oxone dissociation. Once formed, the hydroxyl radical reacts with oxime 99a to form $\mathrm{H}_{2} \mathrm{O}$ and the $\mathrm{O}$-centered radical intermediate $\mathbf{I}$, which undergoes a radical cyclization, delivering the 5-methyl-4,5-dihydroisoxazole radical II. Following, the intermediate II reacts with diphenyl diselenide 21a to yield the desired product 100a, while releasing a Se-centered radical species, that is recovered as diselenide $\mathbf{2 1}$ (Scheme 66a). Regarding the ionic mechanism, the first step is the Oxone-promoted formation of the Se-based electrophilic species III and IV, by the Se-Se bond oxidation. The species IV is protonated to produce the most electrophilic species $\mathbf{V}$. Then, the oxime $99 \mathbf{a}$ reacts with III and/or V to be converted to the seleniranium intermediate VI, which undergoes an intramolecular cyclization process, followed by deprotonation and formation of the desired product 100a (Scheme 66b).

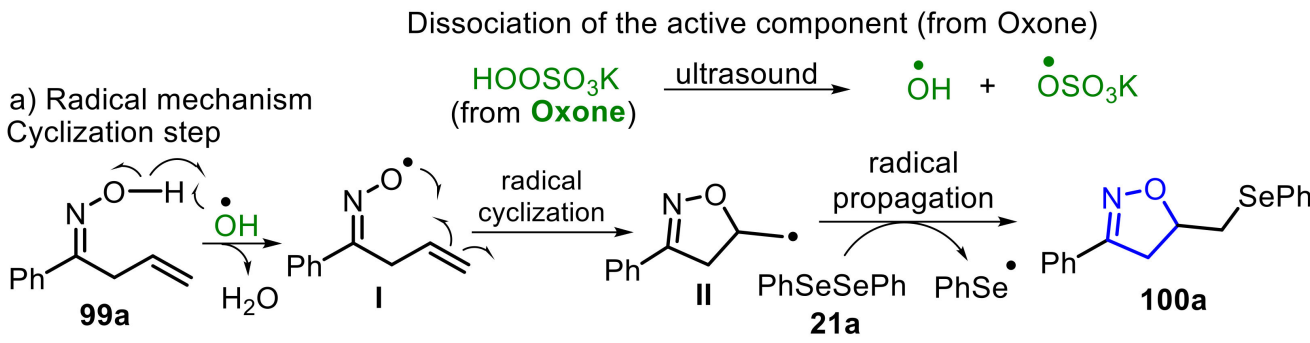

b) Ionic mechanism

Formation of the electrophiles

Activation of intermediate IV

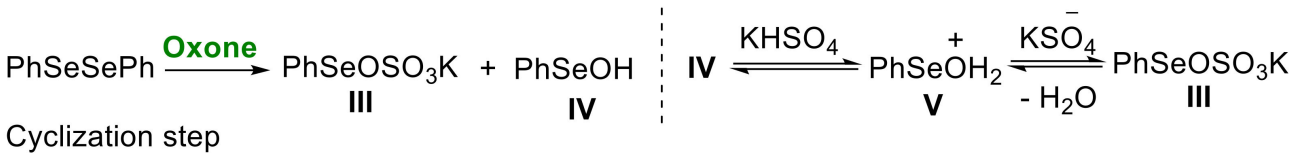

Cyclization step

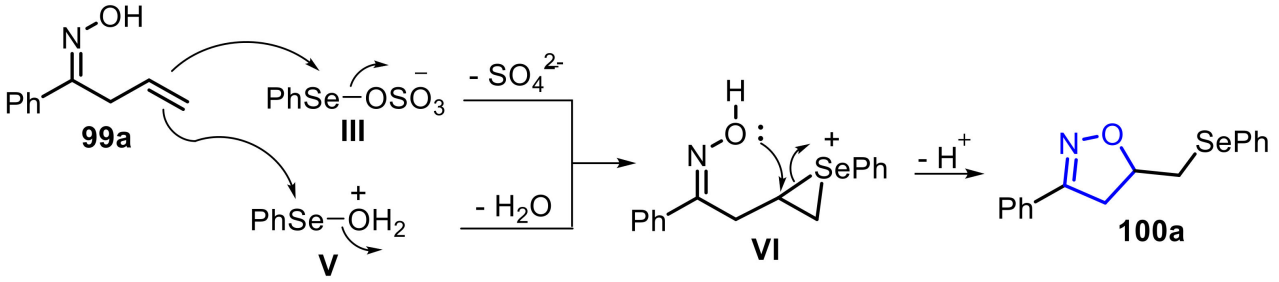

Scheme 66. Plausible reaction mechanism for the Oxone/diselenide-promoted ultrasound-assisted selective cyclization of unsaturated oximes 99. a: Radical mechanism. b: Ionic mechanism.

In 2021, some of us described the Oxone/diselenide-promoted synthesis of 2-aryl(3-organocalcogenyl)thieno[2,3-b]pyridines 101 through the electrophilic cyclization of 3-(arylethynyl)-2-(alkylthio)pyridines 102 (Scheme 67) [61]. A number of electron-rich and electron-deficient diaryl diselenides $\mathbf{2 1}$ were adequately employed as substrate, affording the products 101a-h at good to excellent yields. Additionally, alkyl and heteroaryl

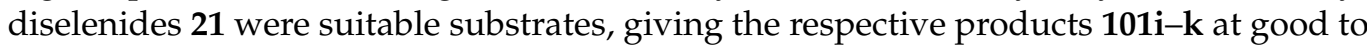
excellent yields. When the glycerol-derived diselenide was used, the unprotected glycol 1011 was obtained at an $85 \%$ yield, due to the Oxone-promoted ketal deprotection ability. No reaction was observed using diphenyl disulfide as chalcogen source, whereas diphenyl ditelluride was discretely converted to $101 \mathrm{n}$ at only a $9 \%$ yield after $24 \mathrm{~h}$. Aiming to improve this resulted, the reaction was conducted in a sealed tube at $100{ }^{\circ} \mathrm{C}$, yielding the tellurium-containing product $101 \mathrm{n}$ at $81 \%$, after $24 \mathrm{~h}$. Regarding the 3-(arylethynyl)-2(propylthio)pyridines 102 counterpart, electron-rich $\left(\mathrm{R}=4-\mathrm{MeC}_{6} \mathrm{H}_{4}\right)$ and electron-deficient $\left(\mathrm{R}=4-\mathrm{ClC}_{6} \mathrm{H}_{4}\right)$ substrates were satisfactorily used, giving the products $101 \mathrm{o}$ and $101 \mathrm{p}$ at a $88 \%$ and $89 \%$ yield, respectively (Scheme 67 ). 
<smiles>[R]c1ccnc([R10])c1C#CBr</smiles>

$+R^{2} Y Y R^{2}$

21

$\mathrm{Y}=\mathrm{Se}, \mathrm{S}, \mathrm{Te}$

$\mathrm{R}=\mathrm{H}$, 5-Me, 6-Me, 5-(phenylethynyl); $\mathrm{R}^{1}$ = alkyl, benzyl

$\mathrm{R}^{2}=$ alkyl, aryl, heteroaryl<smiles>[R]c1ccc([Se]c2c(-c3ccccc3)sc3ncccc23)cc1</smiles>

101a: $\mathrm{R}=\mathrm{C}_{6} \mathrm{H}_{5}, 99 \%, 3 \mathrm{~h}$

101b: $R=M e, 85 \%, 3 \mathrm{~h}$

101c: $R=O M e, 95 \%, 2.5 \mathrm{~h}$

101d: $R=F, 97 \%, 3 h$

101e: $\mathrm{R}=\mathrm{Cl}, 81 \%, 4 \mathrm{~h}$<smiles>O=C(c1ccccc1)c1sc2ncccc2c1[Se]c1ccccn1</smiles>

101j: $83 \%, 2 \mathrm{~h}$<smiles>c1ccc(CSc2c(-c3ccccc3)sc3ncccc23)cc1</smiles>

101m: NF, $3 \mathrm{~h}$<smiles>[R]c1ccccc1[Se]c1c(CCCCCCCCCCCCCCC)sc2ncccc12</smiles>

101f: $\mathrm{R}=\mathrm{Me}, 75 \%, 4 \mathrm{~h}$

101g: $R=O M e, 85 \%, 3 \mathrm{~h}$

101h: $\mathrm{R}=\mathrm{Cl}, 73 \%, 5 \mathrm{~h}$<smiles>[R]c1ccnc2sc([Al])c([R2])c12</smiles>

$70-99 \%$ 


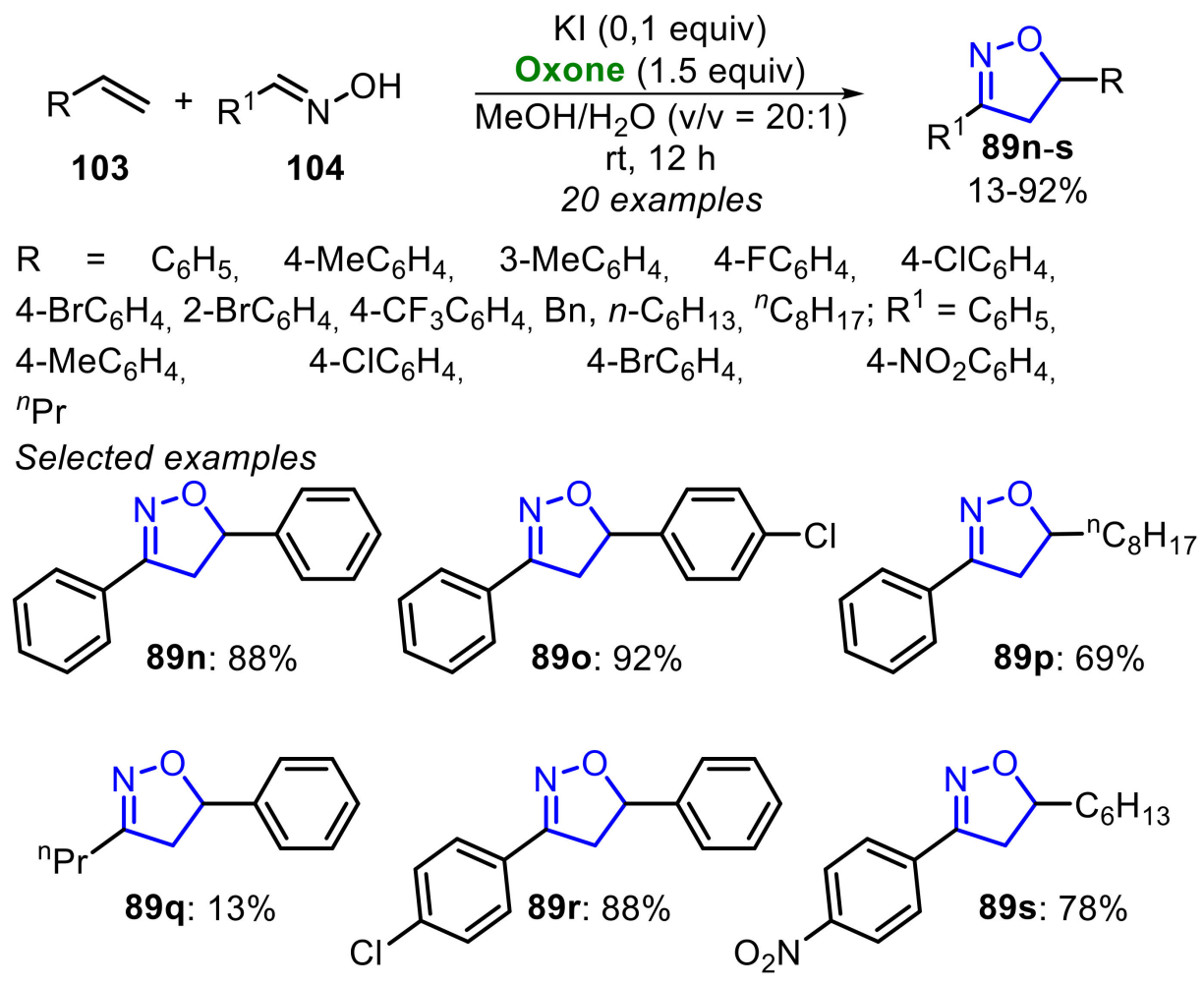

Scheme 68. Catalytic cyclization of alkenes 103 with aldoximes 104.

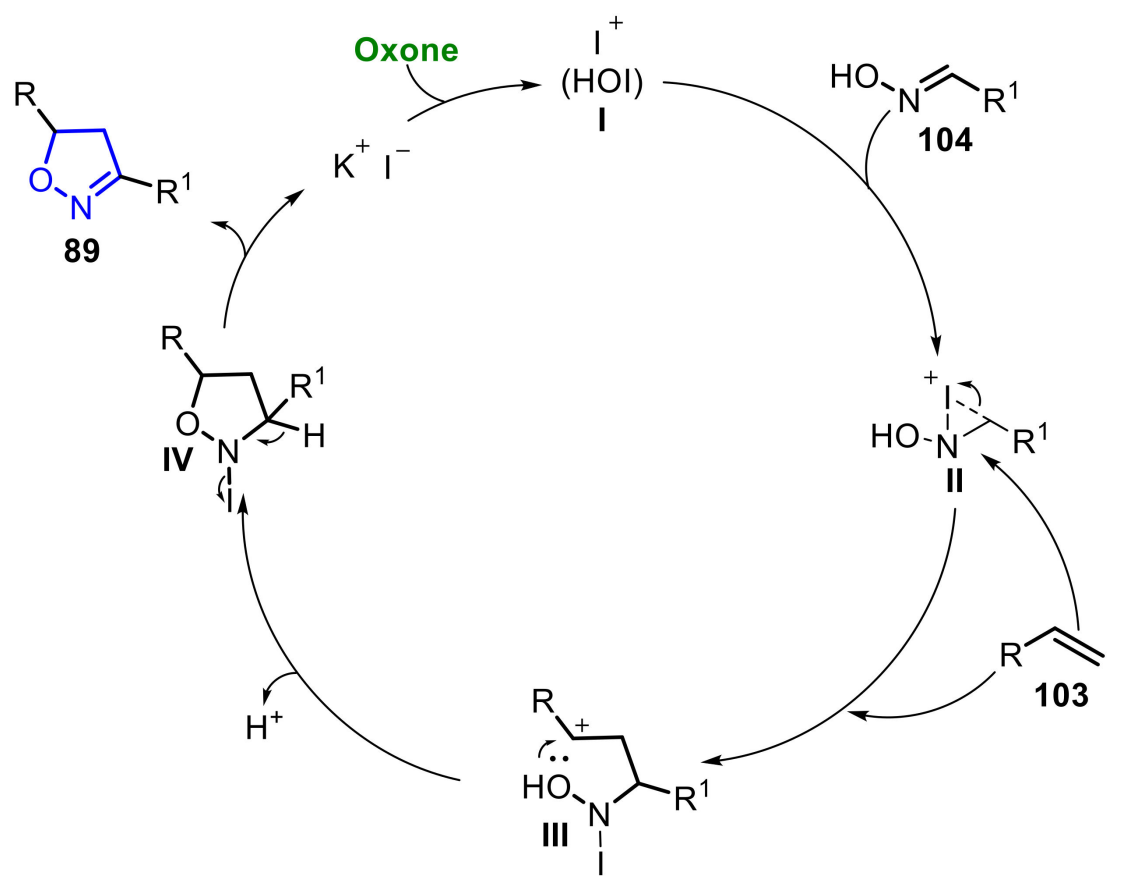

Scheme 69. Mechanism proposed for the synthesis of isoxazoles $89 n-\mathbf{s}$.

In 2020, Ishihara and co-workers developed an oxidative spiroetherification and spiroamination of phenol derivatives 105 and 106 using $\mathrm{I}^{+} /$Oxone catalysis (Scheme 70) [63] In the presence of TBAI (10 mol\%), Oxone (0.6 equiv), and a mixture $\mathrm{CH}_{3} \mathrm{CN} / \mathrm{H}_{2} \mathrm{O}$ as solvent, arenols tethered to a hydroxy group 105 or a secondary amido group 106 were converted to corresponding spiro adducts 107 or 108 at moderate to excellent yields, at room temperature. The protocol was successfully applied to a variety of arenols 105 and 106, including 1- and 2-naphthols and phenols, tethered to hydroxy or sulfonamido 
groups. The oxidative cyclization of secondary and tertiary alcohols $105 \mathrm{~g}$ and $105 \mathrm{~h}$ was also demonstrated and the corresponding spiroethers $107 \mathrm{~g}$ and $107 \mathrm{~h}$ were obtained in good to excellent yields. Interesting, six-membered spiroether $107 \mathbf{i}$ could be synthesized at a $68 \%$ yield (Scheme 70 ).

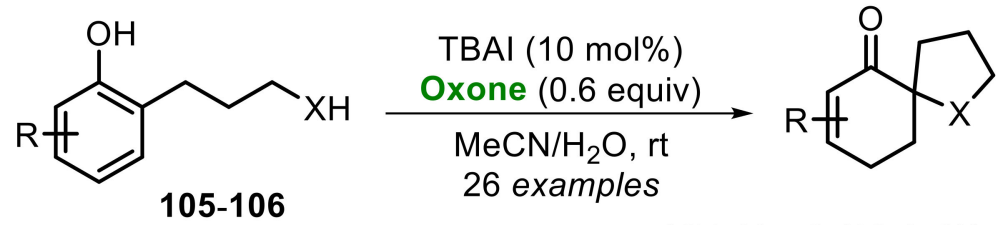

$\mathrm{R}=\mathrm{H}, \mathrm{C}_{6} \mathrm{H}_{5}, \mathrm{Cl}, \mathrm{Br}, \mathrm{Me}, \mathrm{OMe},{ }^{\mathrm{t}} \mathrm{Bu}$

Selected examples<smiles>[X]C12CCCC1(CCCCCC)C(=O)c1ccccc12</smiles>

107a: $90 \%, 1 \mathrm{~h}^{\mathrm{a}}$ 108a: $84 \%, 4 h^{b}$ 108a': $\mathrm{X}=$ NBoc, $73 \%, 5 \mathrm{~h}^{\mathrm{b}}$<smiles>[X]C12CCCC1C(=O)C=Cc1ccc(Br)cc12</smiles>

107d: $84 \%, 1 \mathrm{~h}$ 108d: $81 \%, 12 \mathrm{~h}$<smiles>CC1CC[C@@]2(O1)C(=O)C=Cc1ccccc12</smiles>

107g: $95 \%, 3 \mathrm{~h}^{\mathrm{a}}$ (d.r. $4: 1$ )

$$
h^{b}
$$<smiles>[X]C12CCCC1CC(Br)c1ccccc1C2=O</smiles>

107b: $83 \%, 1 \mathrm{~h}^{\mathrm{a}}$ 108b: $73 \%, 4 h^{c}$
107: $\mathrm{X}=\mathrm{O}(68-95 \%)$

108: $X=$ NTs $(43-84 \%)$<smiles>[X]C12CCCC1C(=O)C=Cc1ccc(OC)cc12</smiles>

107e: $70 \%, 6 \mathrm{~h}^{\mathrm{b}}$ 108e: $76 \%, 12 \mathrm{~h}$<smiles>[X]C12CCCC1(CC)CC(C)c1ccccc1C2=O</smiles>

107c: $78 \%, 1 h^{\mathrm{c}}$ 108c: $43 \%, 2 h^{c}$

${ }^{a}$ TBAI (1 mol\%). ${ }^{b}$ In toluene/ $\mathrm{H}_{2} \mathrm{O} .{ }^{c}$ Oxone (1 equiv).

Scheme 70. $\mathrm{I}^{+} /$Oxone catalyzed oxidative spiroetherification and spiroamination of phenols 105 and 106.

In 2013, Yoshimura, Zhdankin and co-workers reported the cyclization of aldoxime 104 and alkene 103 or alkyne $\mathbf{5 0}$ using catalytic hypervalent iodine, Oxone as a terminal oxidant, and a mixture of MeOH:HFIP: $\mathrm{H}_{2} \mathrm{O}(v / v=10: 10: 1)$ as solvent at room temperature for $24 \mathrm{~h}$ [64]. The reaction involves the initial formation of nitrile oxides, which react with alkenes and alkynes to produce the corresponding isoxazolines 89t-ad (Scheme 71) and isoxazoles 92p-w (Scheme 72). The protocol was expanded to aldoximes 104 and alkenes 103 or alkynes $\mathbf{5 0}$ containing several electron-rich and electron-deficient aryl groups and alkyl groups. By this procedure, a total of sixteen isoxazolines $\mathbf{8 9}$ and eight isoxazoles $\mathbf{9 2}$ were obtained in poor to excellent yields. 


$$
\begin{aligned}
& 3,5-\mathrm{Me}_{2} \mathrm{C}_{6} \mathrm{H}_{3} \mathrm{I}(20 \mathrm{~mol} \%) \\
& =_{\mathrm{R}}+\mathrm{R}^{1}=\mathrm{N}_{\mathrm{OH}}
\end{aligned}
$$

Selected examples<smiles>c1ccc(C2=NOC(c3ccccc3)C2)cc1</smiles>

89t: $88 \%$<smiles>[R]c1ccc(C2CC(c3ccccc3)=NO2)cc1</smiles>

$89 u: R=M e, 78 \%$

$89 v: R=C F_{3}, 99 \%$

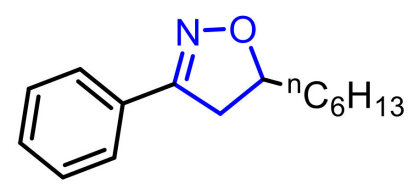

89z: $69 \%$<smiles>[R]CCCC(c1ccccc1)C1CC(c2ccccc2)=NO1</smiles>

89w: $R=3-M e, 81 \%$

89x: $R=2-B r, 89 \%$<smiles>c1ccc(CC2CC(c3ccccc3)=NO2)cc1</smiles>

$89 y: 78 \%$<smiles>Cc1ccc(C2=NOC(c3ccccc3)C2)cc1</smiles>

89ab: $71 \%$<smiles>Clc1ccc(C2=NOC(c3ccccc3)C2)cc1</smiles>

89ac: $77 \%$<smiles>c1ccc(C2=NOC3C4CCC(C4)C23)cc1</smiles>

89aa: $30 \%$

Scheme 71. Oxone-mediated synthesis of isoxazolines 89t-ad.

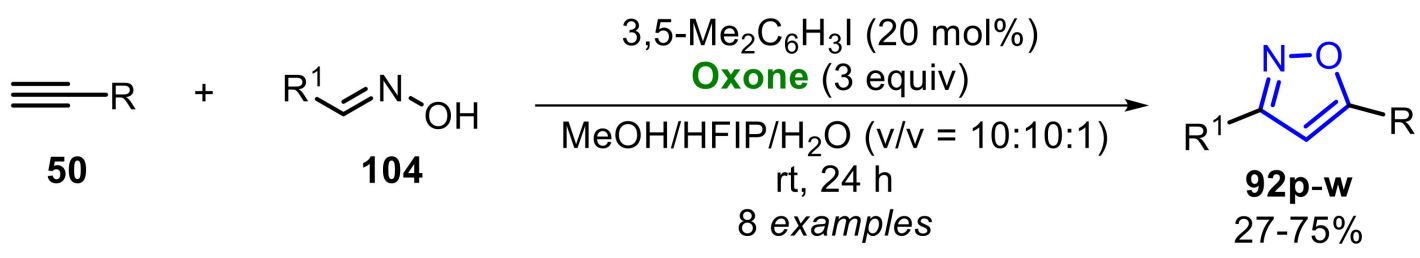<smiles>c1ccc(-c2cc(-c3ccccc3)on2)cc1</smiles>

92p: $75 \%$<smiles>[R]c1ccc(-c2cc(-c3ccccc3)on2)cc1</smiles>

92q: $\mathrm{R}=\mathrm{Me}, 70 \%$ 92r: $\mathrm{R}=\mathrm{Cl}, 70 \%$<smiles>[R]c1ccc(-c2cc(-c3ccccc3)no2)cc1</smiles>

92s: $R=M e, 27 \%$

92t: $\mathrm{R}=\mathrm{Br}, 44 \%$

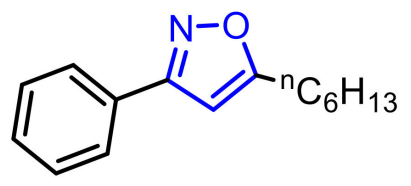

92u: $49 \%{ }^{*}$<smiles>Cc1ccc(-c2cc(-c3ccccc3)on2)cc1</smiles>

92v: $39 \%$ *

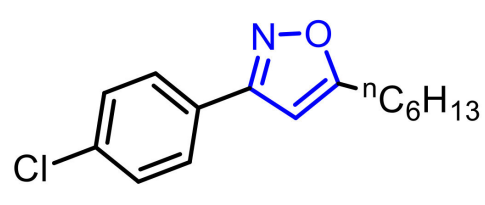

92w: $42 \%$ *

${ }^{*}$ Performed at $40^{\circ} \mathrm{C}$. 
Based on control experiments, a plausible catalytic cyclization mechanism was proposed (Scheme 73). Initially, the activation of iodoarene by Oxone in aqueous HFIP affords the $[\mathrm{ArI}(\mathrm{OH})]^{+}$species I, which reacts with aldoxime $\mathbf{1 0 4}$ to form the hypervalent alkoxy iodane II, via ligand exchange. Then, the intermediate II undergoes reductive elimination of iodoarene to produce the nitrile oxide III, which finally reacts with alkene $\mathbf{1 0 3}$ or alkyne 50 to produce the corresponding isoxazoline $\mathbf{8 9}$ or isoxazole $\mathbf{9 2}$. The regenerated iodoarene continues the next catalytic cycle.

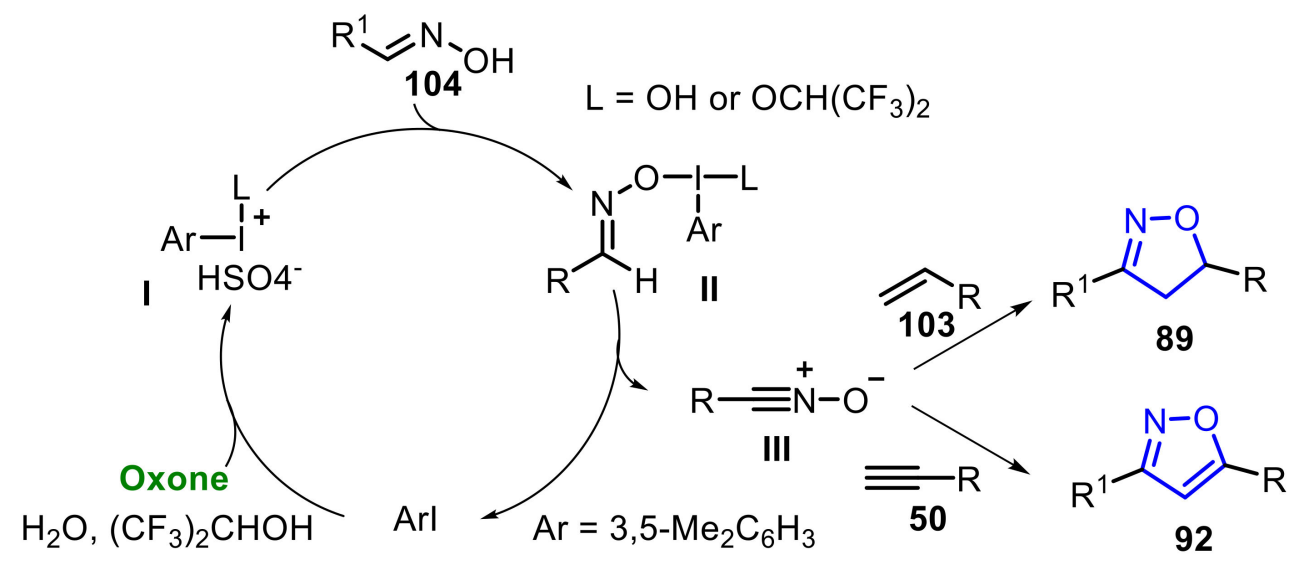

Scheme 73. Plausible mechanism for the catalytic cyclization of the substrate 104.

\section{Conclusions}

This review highlights the recent advances in the Oxone-mediated synthesis of heterocyclic compounds, bringing mechanistic insights, protocol particularities, and a comprehensive discussion about scope and limitations. Among the synthetic approaches discussed herein, several examples are conducted under mild reaction conditions, an environmentally friendly reaction medium and by using alternative energy sources. However, despite the impressive advances delivered so far, many improvements are still required. The finds reached until now are the base to develop innovative approaches in coming years, employing Oxone as a green oxidant to promote the formation of a diversity of chemical bonds, to construct important structure cores. Additionally, we also see good prospects in the application of ultrasound irradiation as a low-demand energy source, driving the application of Oxone in synthetic chemistry to new horizons by triggering innovative activation pathways. In this context, we hope that this review can be a solid source of information, inspiring those interested to devote their studies to the application of Oxone in organic synthesis, aiming to deliver more efficient, robust and greener synthetic approaches.

Author Contributions: Conceptualization, G.P. and E.J.L.; methodology, G.P. and R.G.J.; writingoriginal draft preparation, H.A.G., D.R.A. and F.P.; writing-review and editing, F.P., G.P., R.G.J. and E.J.L.; supervision, G.P. and E.J.L. All authors have read and agreed to the published version of the manuscript.

Funding: This study was financed in part by the Coordenação de Aperfeiçoamento de Pessoal de Nível Superior-Brasil (CAPES)—Finance Code 001; FAPERGS, grant number 19/2551-0001867-3; $\mathrm{CNPq}$ and FINEP.

Institutional Review Board Statement: Not applicable.

Informed Consent Statement: Not applicable.

Conflicts of Interest: The authors declare no conflict of interest.

\section{References}

1. Anastas, P.T.; Warner, J.C. Green Chemistry: Theory and Practice; Oxford University Press: New York, NY, USA, 1998.

2. Anastas, P.; Eghbali, N. Green Chemistry: Principles and Practice. Chem Soc. Rev. 2010, 39, 301-312. [CrossRef] 
3. Lenardão, E.J.; Freitag, R.A.; Dabdoub, J.M.; Batista, A.C.F.; Silveira, C.C. Green Chemistry: The 12 Principles of Green Chemistry and It Insertion in the Teach and Research Activities. Quim. Nova. 2003, 26, 123-129. [CrossRef]

4. Xu, J.; Liang, L.; Zheng, H.; Chi, Y.R.; Tong, R. Green Oxidation of Indoles Using Halide Catalysis. Nat. Commun. 2019, 10, 4754. [CrossRef] [PubMed]

5. Noyori, R.; Aoki, M.; Sato, K. Green Oxidation with Aqueous Hydrogen Peroxide. Chem. Commun. 2003, 1977-1986. [CrossRef]

6. Hussain, H.; Green, I.R.; Ahmed, I. Journey Describing Applications of Oxone in Synthetic Chemistry. Chem. Rev. 2013, 113, 3329-3371. [CrossRef]

7. Quin, L.D.; Tyrell, J.A. Fundamentals of Heterocyclic Chemistry; Wiley-VCH: Weinheim, Germany, 2010.

8. Alvarez-Builla, J.; Vaquero, J.J.; Barluenga, J. Modern Heterocyclic Chemistry; Wiley-VCH: Weinheim, Germany, 2010.

9. Vitaku, E.; Smith, D.T.; Njardarson, J.T. Analysis of the Structural Diversity, Substitution Patterns, and Frequency of Nitrogen Heterocycles among U.S. FDA Approved Pharmaceuticals. J. Med. Chem. 2014, 57, 10257-10274. [CrossRef] [PubMed]

10. Vardanyan, R.; Hruby, V. Synthesis of Best-Seller Drugs; Academic Press: London, UK, 2016.

11. Kaur, N. Microwave-Assisted Synthesis of Fused Polycyclic Six-Membered N-Heterocycles. Synth. Commun. 2014, 45, 273-299. [CrossRef]

12. Wei, Z.-Y.; Chi, K.-Q.; Wang, K.-S.; Hu, J.; Liu, L.-P.; Piao, H.-R. Design, synthesis, evaluation, and molecular docking of ursolic acid derivatives containing a nitrogen heterocycle as anti-inflammatory agents. Bioorg. Med. Chem. Lett. 2018, 28, 1797-1803. [CrossRef]

13. Grande, F.; Occhiuzzi, M.A.; Ioele, G.; Ragno, G.; Garofalo, A. Benzopyroloxazines containing a bridgehead nitrogen atom as promising scaffolds for the achievement of biologically active agentes. Eur. J. Med. Chem. 2018, 151, 121-144. [CrossRef] [PubMed]

14. Hu, Y.; Li, C.-Y.; Wang, X.-M.; Yang, Y.-H.; Zhu, H.-L. 1,3,4-Thiadiazole: Synthesis, reactions, and applications in medicinal, agricultural, and materials chemistry. Chem. Rev. 2014, 114, 5572-5610. [CrossRef] [PubMed]

15. Kashiwa, M.; Sonoda, M.; Tanimori, S. Facile Access to $1 H$-Indazoles through Iodobenzene-Catalyzed C-H Amination under Mild, Transition-Metal-Free Conditions. Eur. J. Org. Chem. 2014, 4720-4723. [CrossRef]

16. Srinivasan, R.; Ruso, J.S.; Nagarajan, N.S.; Kumaran, R.S.; Manickam, G. A Convenient One-Pot Synthesis of Triazolopyridine and Related Heterocycle Fused-Triazole Analogs Through Copper Catalyzed Oxidative Cyclization Strategy. J. Heterocycl. Chem. 2016, 53, 606-614. [CrossRef]

17. Zhang, M.-Z.; Ji, P.-Y.; Liu, Y.-F.; Guo, C.-C. Transition-Metal-Free Synthesis of Carbonyl-Containing Oxindoles from NArylacrylamides and $\alpha$-Diketones via TBHP- or Oxone-Mediated Oxidative Cleavage of C(sp2)-C(sp2) Bonds. J. Org. Chem. 2015, 80, 10777-10786. [CrossRef] [PubMed]

18. Hati, S.; Dutta, P.K.; Dutta, S.; Munshi, P.; Sen, S. Accessing Benzimidazoles via a Ring Distortion Strategy: An Oxone Mediated Tandem Reaction of 2-Aminobenzylamines. Org. Lett. 2016, 16, 3090-3094. [CrossRef] [PubMed]

19. Sriramoju, V.; Kurva, S.; Madabhushi, S. Oxone-mediated annulation of 2-aminobenzamides and 1,2-diaminobenzenes with sec-amines via imine- $N$-oxides: New syntheses of 2,3-dihydroquinazolin-4(1H)-ones and $1 H$-benzimidazoles. New J. Chem. 2018, 42, 3188-3191. [CrossRef]

20. Liao, Y.-Y.; Gao, Y.-C.; Zheng, W.; Tang, R.-Y. Oxidative Radical Cyclization of N-methyl-N-arylpropiolamide to Isatins via Cleavage of the Carbon-carbon Triple Bond. Adv. Synth. Catal. 2018, 360, 3391-3400. [CrossRef]

21. Meng, Y.-N.; Kang, Q.-Q.; Cao, T.-T.; Song, S.-Z.; Ge, G.-P.; Li, Q.; Wei, W.-T. Oxone-Mediated Radical Bicyclization of 1,6-Enynes through Dual $\alpha-\mathrm{C}\left(\mathrm{sp}^{3}\right)-\mathrm{H}$ Functionalization of Ketones under Catalyst- and Base-Free Conditions. ACS Sustain. Chem. Eng. 2019, 7, 18738-18743. [CrossRef]

22. Perin, G.; Nobre, P.C.; Mailahn, D.H.; Silva, M.S.; Barcellos, T.; Jacob, R.G.; Lenardão, E.J.; Santi, C.; Roehrs, J.A. Synthesis of 4-Organoselanyl-1H-pyrazoles: Oxone ${ }^{\circledR}$-Mediated Electrophilic Cyclization of $\alpha, \beta$-Alkynyl Hydrazones by Using Diorganyl Diselenides. Synthesis 2019, 51, 2293-2304. [CrossRef]

23. Jacob, R.G.; Oliveira, D.H.; Peglow, T.J.; Nascimento, J.E.R.; Bartz, R.H. Oxone ${ }^{\circledR}$-Promoted One-Pot Synthesis of 1-Aryl-4(organylselanyl)-1H-pyrazoles. J. Braz. Chem. Soc. 2019, 30, 2144-2152. [CrossRef]

24. More, D.A.; Shinde, G.H.; Shaikh, A.C.; Muthukrishnan, M. Oxone promoted dehydrogenative Povarov cyclization of N-aryl glycine derivatives: An approach towards quinoline fused lactones and lactams. RSC Adv. 2019, 9, 30277-30291. [CrossRef]

25. Huang, K.; Li, J.-N.; Qiu, G.; Xie, W.; Liu, J.-B. ZnBr 2 /Oxone-mediated ipso-cyclization of N-(3-phenylprop-2-yn-1-yl)aniline. RSC Adv. 2019, 9, 33460-33464. [CrossRef]

26. Qiu, G.; Chen, Z.-F.; Xie, W.; Zhou, H. TBAB-Mediated Radical 5-exo-trig ipso-Cyclization of 2-Arylbenzamide for the Synthesis of Spiro[cyclohexane-1,1'-isoindoline]-2,5-diene-3', 4-dione. Eur. J. Org. Chem. 2019, 2019, 4327-4333. [CrossRef]

27. Yang, M.; Hu, X.; Ouyang, B.; Xie, W.; Liu, J.-B. TBAB-mediated radical 6-endo-trig ortho-cyclization of N-aryl-N-(prop-2-yn-1yl)benzenesulfonamide for the synthesis of 3-bromo-1,2-dihydroquinoline. Tetrahedron 2019, 75, 3516-3522. [CrossRef]

28. Chen, D.; Li, J.; Cui, P.; Shan, Y.; Zhao, Y.; Qiu, G. Tandem Oxidative Radical Halogenated Addition of Alkynyl Imines: Regioselective Synthesis of 3-Haloquinolines. Eur. J. Org. Chem. 2020, 2020, 169-175. [CrossRef]

29. Song, S.-Z.; Kang, Q.-Q.; Cao, T.-T.; Lei, K.-W.; Liu, Y.-Y.; Li, Q.; Wei, W.-T. Cu( $\left.\mathrm{NO}_{3}\right)_{2} /$ Oxone-Mediated Radical Nitration Cyclization of 1,6-Enynes. ChemistrySelect 2019, 4, 13380-13383. [CrossRef]

30. Chen, D.; Li, J.; Shan, Y.; Cui, P.; Zhao, Y.; Tian, L.; Qiu, G. Halogen-Radical-Promoted Dearomative Aza-Spirocyclization of Alkynylimines: An Efficient Approach to 3-Halo-Spirocyclohexadienones. Synthesis 2020, 52, 609-618. [CrossRef] 
31. Araujo, D.R.; Goulart, H.A.; Barcellos, A.M.; Cargnelutti, R.; Lenardão, E.J.; Perin, G. Oxone-Promoted Synthesis of 4(Chalcogenyl)isoquinoline- $N$-oxides from Alkynylbenzaldoximes and Diorganyl Dichalcogenides. J. Org. Chem. 2021, 86, 1721-1729. [CrossRef]

32. Pisani, L.; Superchi, S.; D'Elia, A.; Scafato, P.; Rosini, C. Synthetic approach toward cis-disubstituted $\gamma$ - and $\delta$-lactones through enantioselective dialkylzinc addition to aldehydes: Application to the synthesis of optically active flavors and fragrances. Tetrahedron 2012, 68, 5779-5784. [CrossRef]

33. Kaur, P.; Arora, R.; Gill, N.S. Review on oxygen heterocycles. Indo Am. J. Phar. Res. 2013, 3, 2231-6876.

34. Cossy, J.; Guérinot, A. Natural products containing oxygen heterocycles—Synthetic advances between 1990 and 2015. Adv. Heterocycl. Chem. 2016, 119, 107-142.

35. Wang, R.-X.; Yuan, S.-T.; Liu, J.-B.; Wu, J.; Qiu, G. Regioselective 5-exo-dig oxy-cyclization of 2-alkynylbenzamide for the synthesis of isobenzofuran-1-imines and isobenzofuran. Org. Biomol. Chem. 2018, 16, 4501-4508. [CrossRef] [PubMed]

36. Wang, Y.-H.; Ouyang, B.; Qiu, G.; Zhou, H.; Liu, J.-B. Oxidative oxy-cyclization of 2-alkynylbenzamide enabled by TBAB/Oxone: Switchable synthesis of isocoumarin-1-imines and isobenzofuran-1-imine. Org. Biomol. Chem. 2019, 17, 4335-4341. [CrossRef] [PubMed]

37. Lv, S.; Liu, H.; Kang, J.; Luo, Y.; Gong, T.; Dong, Z.; Sun, G.; He, C.; Sun, X.; Wang, L. Palladium-catalyzed enol/enolate directed oxidative annulation: Functionalized naphthofuroquinone synthesis and bioactivity evaluation. Chem. Commun. 2019, 55, 14729-14732. [CrossRef] [PubMed]

38. Wang, Y.-H.; Qiu, G.; Zhou, H.; Xie, W.; Liu, J.-B. Regioselective cyclization of 2-alkynylbenzoic acid in water for the synthesis of isocoumarin. Tetrahedron 2019, 75, 3850-3855. [CrossRef]

39. Zheng, Y.; Liu, M.; Qiu, G.; Xie, W.; Wu, J. Synthesis of 3-(Bromomethylene)isobenzofuran-1(3H)-ones through regioselective 5-exo-dig bromocyclization of 2-alkynylbenzoic acids. Tetrahedron 2019, 75, 1663-1668. [CrossRef]

40. Goulart, H.A.; Neto, J.S.S.; Barcellos, A.M.; Silva, K.B.; de Moraes, M.C.; Jacob, R.G.; Lenardão, E.J.; Barcellos, T.; Perin, G. Synthesis of 4-Selanyl- and 4-Tellanyl-1H-isochromen-1-ones Promoted by Diorganyl Dichalcogenides and Oxone. J. Org. Chem. 2021, 86, 14016-14027. [CrossRef]

41. Uyanik, M.; Kato, T.; Sahara, N.; Katade, O.; Ishihara, K. High-Performance Ammonium Hypoiodite/Oxone Catalysis for Enantioselective Oxidative Dearomatization of Arenols. ACS Catal. 2019, 9, 11619-11626. [CrossRef]

42. Hellwig, P.S.; Peglow, T.J.; Penteado, F.; Bagnoli, L.; Perin, G.; Lenardão, E.J. Recent Advances in the Synthesis of Selenophenes and Their Derivatives. Molecules 2020, 25, 5907-6010. [CrossRef]

43. Pander, P.; Motyka, R.; Zassowski, P.; Lapkowski, M.; Swist, A.; Data, P. Electrochromic Properties of Novel Selenophene and Tellurophene Derivatives Based on Carbazole and Triphenylamine Core. J. Phys. Chem. C 2017, 121, 11027-11036. [CrossRef]

44. Nakano, M.; Mori, H.; Shinamura, S.; Takimiya, K. Naphtho[2,3-b:6,7- $b^{\prime}$ ]dichalcogenophenes: Syntheses, Characterizations, and Chalcogene Atom Effects on Organic Field Effect Transistor and Organic Photovoltaic Devices. Chem. Mater. 2012, 24, 190-198. [CrossRef]

45. Mahmoud, A.B.A.; Kirsch, G.; Peagle, E. Biologically Active Selenophenes and Benzo[b]selenophenes. Curr. Org. Synth. 2017, 14, 1091-1101.

46. Costea, T.; Bădiceanu, C.D.; Nuță, D.M.; Gîrd, C.E.; Limban, C.; Karampelas, O.; Avram, S. Antioxidant Activity And Drug Profile Of Several Thiourea Derivatives Of 2-Thiophene Carboxylic Acid. Farmacia 2020, 68, 1047-1054. [CrossRef]

47. Soares, L.K.; Barcellos, A.M.; Neto, J.S.S.; Alves, D.; Lenardão, E.J.; Rosati, O.; Santi, C.; Perin, G. Dichalcogenides/Oxone ${ }^{\circledR}{ }_{-}$ Mediated Cyclization of (Z)-Chalcogenoenynes under Ultrasound Irradiation. ChemistrySelect 2020, 5, 9813-9819. [CrossRef]

48. Hellwig, P.S.; Guedes, J.S.; Barcellos, A.M.; Perin, G.; Lenardão, E.J. Synthesis of 3,4-Bis(Butylselanyl)Selenophenes and 4Alkoxyselenophenes Promoted by Oxone ${ }^{\circledR}$. Molecules 2021, 26, 2378-2392. [CrossRef] [PubMed]

49. Hellwig, P.S.; Guedes, J.S.; Barcellos, A.M.; Jacob, R.G.; Silveira, C.C.; Lenardão, E.J.; Perin, G. Synthesis of benzo[b]chalcogenophenes fused to selenophenes via intramolecular electrophilic cyclization of 1,3-diynes. Org. Biomol. Chem. 2021, 19, 596-604. [CrossRef] [PubMed]

50. Perin, G.; Soares, L.K.; Hellwig, P.S.; Silva, M.S.; Neto, J.S.S.; Roehrs, J.A.; Barcellos, T.; Lenardão, E.J. Synthesis of 2,3-bisorganochalcogenylbenzo[b]chalcogenophenes promoted by Oxone. New J. Chem. 2019, 43, 6323-6331. [CrossRef]

51. Alla, S.K.; Sadhu, P.; Punniyamurthy, T. Organocatalytic Syntheses of Benzoxazoles and Benzothiazoles using Aryl Iodide and Oxone via C-H Functionalization and C-O/S Bond Formation. J. Org. Chem. 2014, 79, 7502-7511. [CrossRef]

52. Moriyama, K.; Nishinohara, C.; Sugiue, T.; Togo, H. Oxidative oxygen-nucleophilic bromo-cyclization of alkenyl carbonyl compounds without organic wastes using alkali metal reagents in green solvent. RSC Adv. 2015, 5, 85872-85878. [CrossRef]

53. Daswani, U.; Dubey, N.; Sharma, P.; Kumar, A. A new NBS/Oxone promoted one-pot cascade synthesis of 2-aminobenzimidazoles/2aminobenzoxazoles: A facile approach. New J. Chem. 2016, 40, 8093-8099. [CrossRef]

54. Sharma, S.; Pathare, R.S.; Maurya, A.K.; Gopal, K.; Roy, T.K.; Sawant, D.M.; Pardasani, R.T. Ruthenium Catalyzed Intramolecular C-S Coupling Reactions: Synthetic Scope and Mechanistic Insight. Org. Lett. 2016, 18, 356-359. [CrossRef]

55. Sen, A.; Takenaka, K.; Sasai, H. Enantioselective Aza-Wacker-Type Cyclization Promoted by Pd-SPRIX Catalyst. Org. Lett. 2018, 20, 6827-6831. [CrossRef] [PubMed]

56. Imai, T.; Togo, H. One-Pot Preparation of 3-Arylisoxazole-4,5-dicarboxylates from Benzylic Chlorides and Acetylenedicarboxylates. Eur. J. Org. Chem. 2018, 2018, 1377-1383. [CrossRef] 
57. Bhatt, A.; Singh, R.K.; Kant, R. A convenient one-pot synthesis of 3,5-diarylisoxazoles via oxidative cyclisation using catalytic $\mathrm{CuBr}_{2}$ and oxone. Tetrahedron Lett. 2019, 60, 1143-1147. [CrossRef]

58. Goulart, H.A.; Neto, J.S.S.; Barcellos, A.M.; Barcellos, T.; Silva, M.S.; Alves, D.; Jacob, R.G.; Lenardão, E.J.; Perin, G. Synthesis of 5H-Selenopheno[3,2-c]isochromen-5-ones Promoted by Dialkyl Diselenides and Oxone ${ }^{\circledR}$. Adv. Synth. Catal. 2019, 361, 3403-3411. [CrossRef]

59. Wang, Y.-C.; Liu, J.-B.; Zhou, H.; Xie, W.; Rojsitthisak, P.; Qiu, G. Ortho-Hydroxylative ipso-Cyclization of N-arylpropiolamide. J. Org. Chem. 2020, 85, 1906-1914. [CrossRef] [PubMed]

60. Araujo, D.R.; Lima, Y.R.; Barcellos, A.M.; Silva, M.S.; Jacob, R.G.; Lenardão, E.J.; Bagnoli, L.; Santi, C.; Perin, G. UltrasoundPromoted Radical Synthesis of 5-Methylselanyl-4,5-dihydroisoxazoles. Eur. J. Org. Chem. 2020, 586-592. [CrossRef]

61. Peglow, T.J.; Bartz, R.H.; Barcellos, T.; Schumacher, R.F.; Cargnelutti, R.; Perin, G. Synthesis of 2-Aryl-(3-Organochalcogenyl)Thieno [2,3-b]Pyridines Promoted by Oxone ${ }^{\circledR}$. Asian J. Org. Chem. 2021, 10, 1198-1206. [CrossRef]

62. Yoshimura, A.; Zhu, C.; Middleton, K.R.; Todora, A.D.; Kastern, B.J.; Maskaev, A.V.; Zhdankin, V.V. Hypoiodite mediated synthesis of isoxazolines from aldoximes and alkenes using catalytic KI and Oxone as the terminal oxidant. Chem. Commun. 2013, 49, 4800-4802. [CrossRef] [PubMed]

63. Uyanik, M.; Sahara, N.; Katade, O.; Ishihara, K. Chemoselective Oxidative Spiroetherification and Spiroamination of Arenols Using I+ /Oxone Catalysis. Org. Lett. 2020, 22, 560-564. [CrossRef]

64. Yoshimura, A.; Middleton, K.R.; Todora, A.D.; Kastern, B.J.; Koski, S.R.; Maskaev, A.V.; Zhdankin, V.V. Hypervalent Iodine Catalyzed Generation of Nitrile Oxides from Oximes and their Cycloaddition with Alkenes or Alkynes. Org. Lett. 2013, 15, 4010-4013. [CrossRef] [PubMed] 